\title{
Aquarium Notes
}

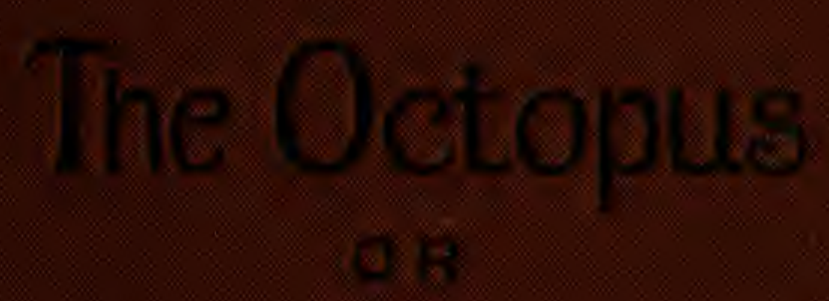

The Devil Fish of Fiction WNO OF FACT. 


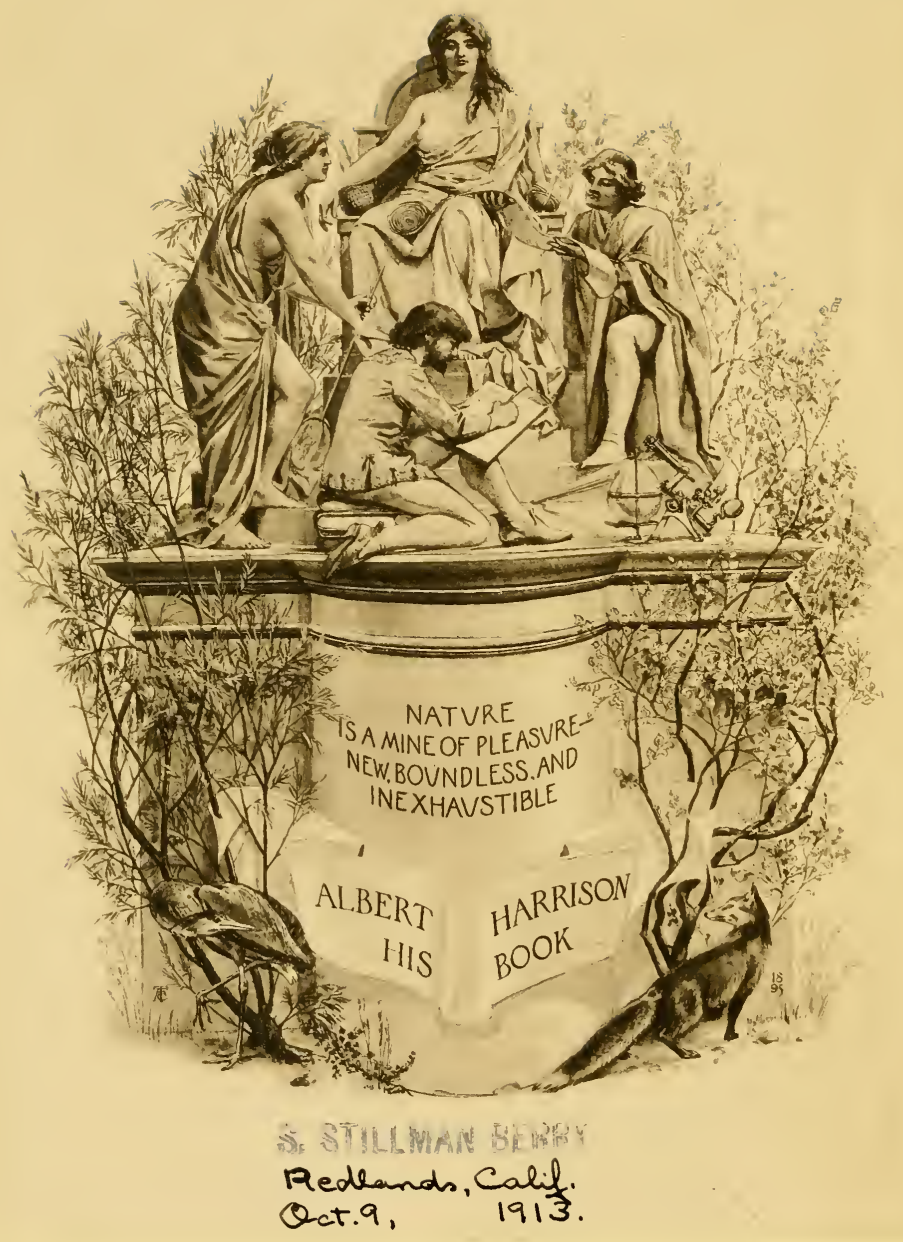






\section{THE OCTOPUS;}

OR,

THE “DEVIL-FISH" OF FICTION AND OF FACT. 


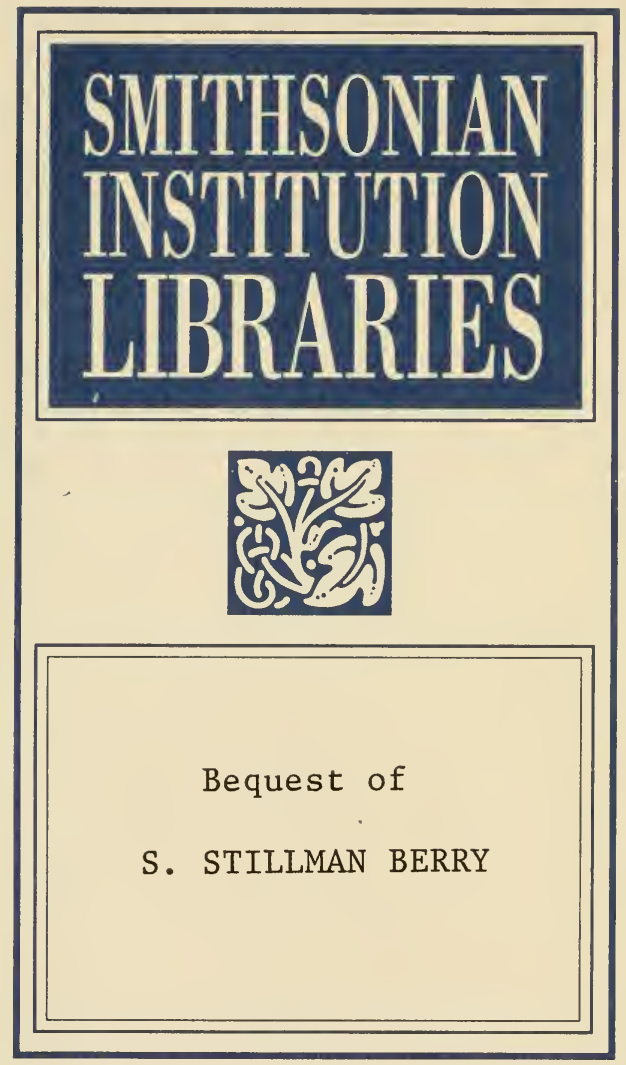





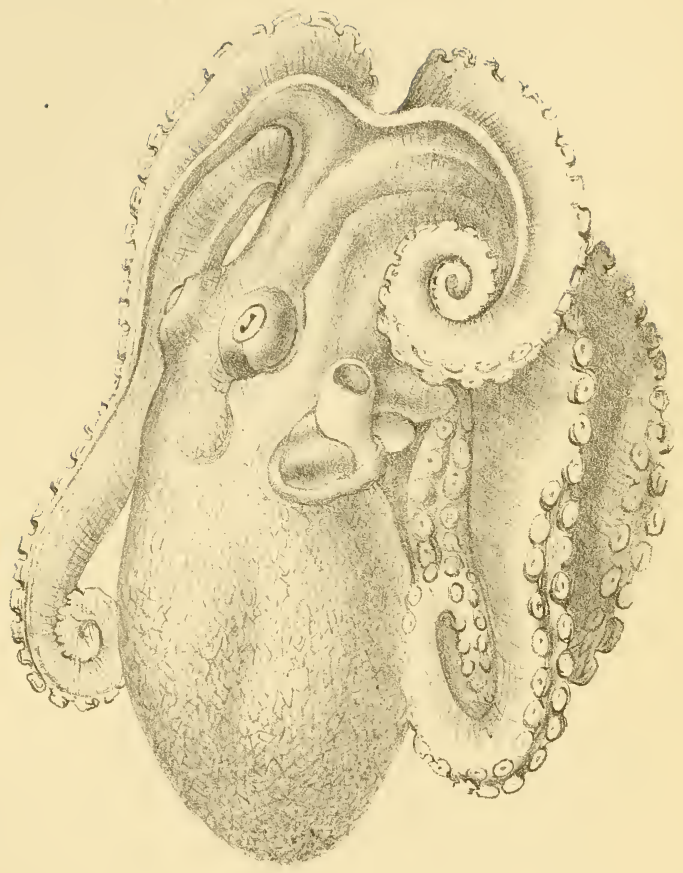

THE OCTOPUS

(Octopus vulgaris.) 


\section{THE OCTOPUS;}

OR,

THE "DEVIL-FISH" OF FICTION AND OF FACT.

\section{By HENRY LEE, \\ F.L.S., F.G.S., F.Z.S., \&.c.,}

NATURALIST OF THE BRIGHTON AQUARIUM.

WITH ILLUSTRATIONS.

\section{LONDON :}

CHAPMAN AND HALL, I93, PICCADILLY.

I 875 . 
LONDON :

BRADEURY, AGNEW, \& CO,, PRINTERS, WHITEFRIARS.

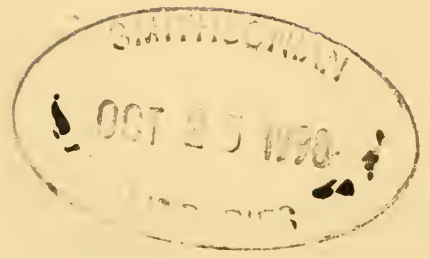




\section{E Dedricate this little book}

TO MY VENERABLE FRIEND,

\section{DR. JAMES SCOTT BOWERBANK. F.R.S., \&c.,}

ONE OF THE ORIGINATURS OF THE WATER VIVARIUM;

TO Whose VALUABLE ADVICE AND CHEERING ENCOURAGEMENT

I, LIKE MANY OTHERS, AM INDEBTED FOR THE CONFIRNIATION AND INCREASE OF AN EARLY LOVE OF TIIE STUDY OF NATURAL HISTORY.

H. L. 



\section{PREFACE.}

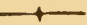

WHEN I accepted the position of Naturalist of the Brighton Aquarium, after the death of my valued friend John Keast Lord, it became my pleasant duty to watch and record events and circumstances connected with the habits and development of the denizens of the tanks.

My notes of observations have, from time to time, appeared in the Natural History columns of Land and Water, and have been honoured by frequent quotation in the Times and other newspapers. Grateful for the kind reception accorded to them in their original form, I re-publish them with considerable additions. They have, in fact, been almost entirely re-written. I venture to hope that they may be interesting to the public, and of some little value to science.

I have always endeavoured to observe carefully, to describe faithfully, to record facts rather than to propound theories, and to relate what I have seen and learned in language comprehensible by all. 
With excellent opportunities of studying the habits and movements of living cephalopods, and with dead specimens of these animals on the table before me, I have followed, scalpel in hand, the minute description of their anatomy given by Professor Owen, in his masterly treatise in the "Cyclopædia of Anatomy," and by De Ferrussac and D'Orbigny in their splendid monograph on the same subject; the two great sources from which almost all, if not all, subsequent writers have drawn much of their information. Quotations from other authors will be found duly noted.

I am indebted to my friend $\mathrm{Mr}$. Thomas Davidson, F.R.S., \&c., for the beautiful portrait of the Octopus, which forms the frontispiece to this volume; to Mrs. Edward Harris for the drawing of its eggs (fig. 6) ; to Miss Gertrude Woodward for that of its tongue (fig. 4) ; and to Messrs. West and Co., and Mr. Charles A. Ferrier, for the care they have respectively bestowed on the lithographing and engraving of the illustrations.

HENRY LEE.

BRIGHTON AQUARIUM, August, 1875. 


\section{CONTENTS.}

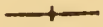

PAGE

INTRODUCTION • . . . . . . . . . . . . xiii

CHAPTER I.

THE OCTOPUS AND ITS RELATIVES. • • • • . . . $~ I$

CHAPTER II.

OCTOPODS I HAVE KNOWN • • • • . . . . . 7

CHAPTER III.

"THE TOILERS OF THE SEA" . . . . . . . . I2

CHAPTER IV.

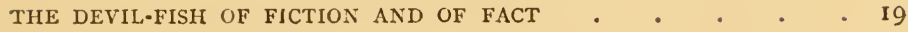

CHAPTER V.

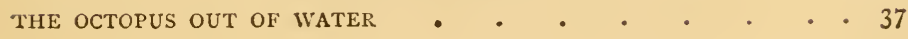

CHAPTER VI.

NEW LIMBS FOR OLD ONES

CHAPTER VII.

SPAWNING OF THE OCTOPUS . 


\section{CHAPTER VIII.}

CUTTLES AND SQUIDS. $\quad$ • . . . . . . . . . 67

CHAPTFR IX.

economic Value of CUttle-fishes . . . . . . . $\quad 8_{3}$

\section{CHAPTER $\mathrm{X}$.}

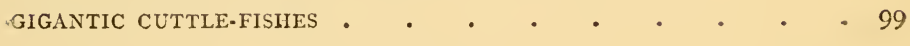




\section{LIST OF ILLUSTRATIONS.}

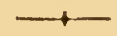

FIG.

PAGE

THE OCTOPUS (Octopus vulgaris) . . . . . Frontispiece.

I. THE PAPER NaUtilus (Argonauta Argo). • . . . . 5

2. SUCKER OF THE OCTOPUS . . . . . . . . . 2 I

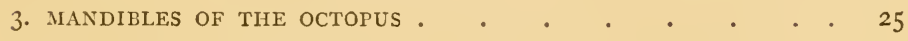

4. TONGUE OF THE OCTOPUS . . . . . . . . . 26

5. THE OCTOPUS SWIMMING. • . . . . . . . 28

6. EGGS OF THE OCTOPUS. • . . . . . . . $\quad 5^{8}$

7. The COMmon CUTtLE-Fish (Sepia officinalis) . . . . . 67

8. SEPIOLA RONDELETII • . . . . . . . . . 70

9. THE COMMON SQUID (Loligo vulgaris) • • • • . . 7 I

IO. EgGS OF THE CUTtLe-FISH (Sepia officinalis) . . . . 73

II. SPAWN OF THE COMMON SQUID (Loligo anlgaris) . • . . $7_{6}^{6}$

12. FAC-Simile of DE MONTFORT's "Poulpe Colossal" . . . IOL 



\section{INTRODUCTION.}

MORE than 2200 years ago-nearly four centuries before the Evangelists wrote their imperishable histories of the events on which the faith of Christendom is based-Aristotle, the celebrated naturalist of Stageira, in Macedonia, recorded observations of the habits and reproduction of the Octopus which clearly show that he was more intimately acquainted with its mode of life than any writer of a later date between his day and ours.

For how many centuries before his time facts and fallacies concerning this curious animal were handed down from father to son in oral tradition, and from generation to generation in manuscript, ages before printing was invented, it is impossible to say: he occasionally quotes from the works of previous writers, and Strabo tells us that he had a good collection of books, and was the first philosopher who possessed a library of his own. But the faint glimmering of information to be derived from early bookish lore was insufficient to satisfy his desire and that of his sovereign for more complete and perfect knowledge. Alexander the Great, who, in his youth, was under his tuition for ten years, gave him, therefore, the means of extending his researches, by placing at his disposal a large sum of money and a staff of assistants. According to Pliny the latter were sent to various parts of Asia and Greece under orders to collect animals of all kinds, and by means of vivaria, fishponds, aviaries, \&c., 
"to watch their habits so closely that nothing relating to them should remain unknown." Aristotle thus accumulated a multitude of notes and observations, many of which, though ridiculed and discredited by later zoologists, were marvellously accurate; and from them constructed a work elaborate in its details, grand in its conception and idea, and comprehensive as a general history of the Animal Kingdom.

Amongst the inhabitants of the sea therein described by him is, as I have said, the Octopus or Polypus, and many of his statements concerning it and its congeners have been remarkably confirmed by recent observations. This animal has, therefore, been long known to raturalists. The ancient Egyptians figured it amongst their hieroglyphics; * the Greeks and Romans were well acquainted with it; and since the time of Homer many of the ancient poets and authors have mentioned it in their works.

There is little doubt that the idea of the Lernean Hydra, whose heads grew again when cut off by Hercules, originated from a knowledge of the Octopus. Diodorus relates of it that it had a hundred heads; Simonides says fifty; but the generally received statement is that of Apollodorus, Hyginus, \&c., that it had only nine. Reduce the number by one, and we have an animal with

* An interesting proof that the ancient Egyptians were also acquainted with other cephalopods has been communicated to me by Mr. Eugenius Birch, the architect of the Brighton Aquarium. Whilst on a journey to Nubia, up the Nile, in January, 1875 , he visited the temple of Bayr-el-Bahree, Thebes (date, I 700 B.C.), the entrance to which had been deeply buried beneath the light, wind-drifted sand accumulated during many centuries. By order of the Khedive access was recently obtained to its interior by the excavation and removal of this deep deposit; and amongst the hieroglyphics on the walls were found, between the zig-zag horizontal lines which represent water, figures of various fishes so accurately portrayed as to be easily identified. With them was the outline of a squid 14 inches long. As this temple is 500 miles from the delta of the Nile it is remarkable that nearly all the fishes there represented are of marine species. 
eight out-growths from its trunk-the type of an Octopus, which is really capable of rapidly developing afresh, and replacing by new ones, one or all of its eight limbs in case of their being amputated or injured.* According to the legend, Hercules dipped his arrow-heads in the gall of the hydra, and, from its poisonous nature, all the wounds he inflicted with them on his enemies proved fatal. It is worthy of notice that the ancients attributed to the Octopus the possession of a similarly venomous secretion. Thus Oppian writes :-

"The crawling preke a deadly juice contains, Injected poison fires the wounded veins."

Fishermen have been familiar with this animal from time immemorial; but in modern days, although naturalists have occasionally noted some peculiarities of its structure and habits, public attention was never particularly attracted to it until, within the last few years, Victor Hugo brought it again into notice by the publication of his "Les Travailleurs de la Mcr." Since then it has been constantly exhibited in aquaria, and "Octopus" has become a household word.

* See page 49 . 



\section{THE OCTOPUS.}

\section{CHAPTER I.}

THE OCTOPUS AND ITS RELATIVES.

IT is not my intention to formally portray the anatomy of the Octopus, - the nature and uses of its various organs will be sufficiently indicated in the course of my remarks,--but before giving an account of its life-history and habits, I will briefly describe its affinities, and the position it occupies in the scale of Nature.

One of the great primary groups or divisions of the Animal Kingdom is that of the soft-bodied Mollusca; which includes the cuttle, the oyster, the snail, \&c. It has been separated into five "classes," of which the one we have especially to notice is the Ccpralopoda," or "head-footed,"-the animals belonging to it having their feet, or the organs which correspond with the foot of other molluscs, so attached to the head as to form a circle or coronet round the mouth. Some of these have the foot divided into eight lobes, and are therefore called the Octopoda: $\uparrow$ others have, in addition to the eight feet, lobes, or arms, two longer tentacular appendages, making ten in all, and are consequently called the Decapoda.

* From the Greek words cephale, the head; and poda, feet.

+ From octo, eight; and pous (foda), feet. 
Of the ten-footed section of the cephalopods, there are four "families"; two only of which exist in Britain-the Teuthidæ, and the Sepiidæ. The Teuthidæ are the Squids, or Calamaries, represented by the long-bodied Loligo vulgaris, that has along its back a gristly, translucent stiffener, shaped like a quill pen; from which and its ink it derives its names of "calamary," "pen-and-ink fish," and "sea-clerk." The Sepiidæ are the Cuttles; as a type of which we may take the common "cuttle-fish," Sepia officinalis, the owner of the hard, calcareous shell often thrown up on the shore, and known as "cuttle-bone," or "sea-biscuit."

Of the eight-footed cephalopods,-the Octopoda,--there are two families; namely, the Octopidæ, and the Argonautidæ. The first only is found on our coasts. The British members of it are the common Octopus, O. vulgaris, and the Eledone, $E$. cirrosa, a genus chiefly distinguished from the octopus by its having only one row of suckers, instead of two, along its arms or feet. The Argonautidæ, which inhabit warmer seas than ours, and approach no nearer to us than the Mediterranean and Adriatic, are represented by Argonauta argo, the "Paper Nautilus,"-so called from the peculiar texture of its shell, and the similarity of its shape to that of the true Nautilus, $N$. pompilius, from which, however, it differs greatly in organisation.

All of these four "families" have two plume-like gills, - one on each side-and are therefore placed by Professor Owen in the " order," Dibranchiata. To this order belong also the extinct Belemnites, and the still living Spirula, only one entire specimen of which has ever been obtained, and that was in New Zealand, though its beautiful internal shells are sometimes thrown up on the shores of Devon and Cornwall.

The Tetrabranchiata, or four-gilled cephalopods, are represented by a single living genus-the Pearly Nautilus, $N$. pompilius,-but in Silurian times by 34 genera, and more than 1400 species. ${ }^{*}$

* See an interesting article on the fossil and recent cephalopoda, by Henry Woodward, F.R.S., in the Student, Nos. xix. and xxii. 
The following diagram will help to explain the relationship of the Octopus to the rest of the cephalopoda.

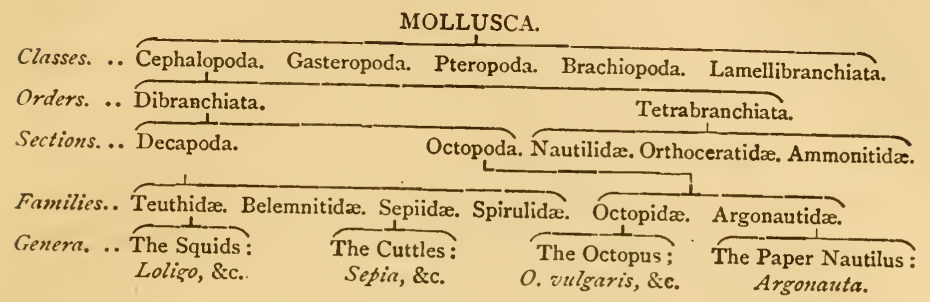

It will be seen that it may be said to be first cousin to the Argonaut, or "Paper Nautilus," and second cousin to the cuttle and squid.

The Argonaut branch of the family is in possession of all the house property, which seems to have been entailed on the female line; for the paper-nautilus is, in fact, a female octopod provided with a shell in which to carry and protect her eggs. Instead of the whole of the eight arms tapering to a point, as in the octopus, two of the dorsal limbs are flattened out at their extremity, and from their membranes she secretes, and, if necessary, repairs the shell, and, by applying them closely to its outer surface on each side, holds herself within it ; for it is not fastened to her body by any attaching muscles.*

* In the Appendix to Sir Edward Belcher's "Voyage of the Samarang," Mr. Arthur Adams, the Assistant Surgeon attached to the Expedition, gives some valuable information concerning the Argonaut, numerous specimens of which he had opportunities of capturing in the South Atlantic, and observing. He says :- "There is not the slightest vestige of any muscular attachment. This remarkable cephalopod carries about her eggs in a light calcareous nest, which she firmly retains possession of by means of the broad, expanded, delicate membranes of the posterior pair of tentacles. When disturbed or captured, however, she loosens her hold, and, leaving her cradle to its fate, swims away independent of her shell." He adds that "having once left her shell she las not the ability, nor, perhaps, the sagacity, to re-enter her nest and resume the guardianship of her eggs." From observations of the breeding habits of other octopods I doubt this. 
The male argonaut is very small,-not more than an inch in length,-and has no shell. Hence, even by eminent naturalists, as Dumeril and De Blainville, it was long regarded as doubtful whether the shell was really secreted by the female, or whether, like the hermit-crab, she borrowed for her protection the empty habitation of some other mollusc.

It is an old belief, sanctioned by Aristotle, that the broad membranous expansions of the two arms, are hoisted by the animal as sails; and that in calm weather it sits in its boat-like shell, and floats over the smooth surface of the sea, steering and paddling with its other arms; and that, when danger threatens, it lowers its masts, and sinks beneath the waves.

Oppian, in his "Halieutics," poetically expresses his opinion that it served as a model for the man who first conceived the idea of constructing a ship, and embarking on the waters :-

"If humble guess may probably divine, And trace th' improvement to the first design, Some wight of prying search, who wond'ring stood When softer gales had smoothed the dimpled flood, Observed these careless swimmers floating move, And how each blast the easy sailor drove; Hence took the hint, hence formed th' imperfect draught, And ship-like fish the future seaman taught. Then mortals tried the shelving hull to slope, To raise the mast, and twist the stronger rope, To fix the yards, let fly the crowded sails,

Sweep through the curling waves, and court auspicious gales."

This pretty fable was exploded in 1837 by Captain Sander Rang, an officer of the French navy, and Port-captain at Algiers, who carefully followed up some experiments communicated to him by Mrs. Power, a French lady then residing at Messina ; and the structure and purpose of the two flattened limbs is now clearly understood.*

Instead of floating in its pleasure-boat over the sea, the

* Charlesworth's Magazine of Natural History, Sept. IS37 ; p. 393. 
argonaut ordinarily crawls along the bottom, carrying its shell above it, keel uppermost ; and the broad extremities of the two arms are not hoisted as sails, nor allowed, when at rest, to dangle over the side of the "boat," but are used as a kind of hood by which the animal retains the shell in its proper position, as a man bearing a load on his shoulders holds it with his hands. When it

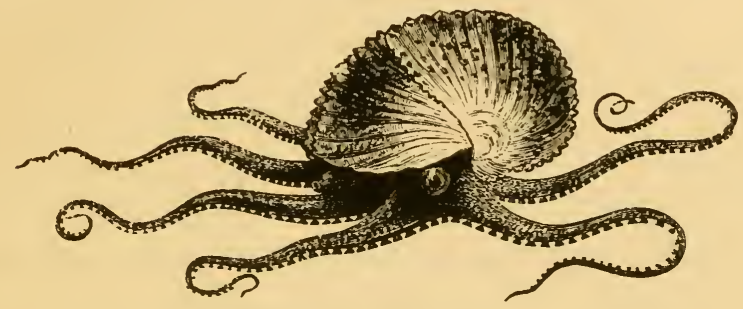

Fig. 1. The Paper Nautilus (Argonanta argo).

The membrane is shewn partially retracted and the shell exposed.

comes to the surface, or progresses by swimming instead of walking, it does so in the same manner as the octopus; namely, by the forcible expulsion of water from its funnel-like tube.*

This "paper-sailor," then, whom the poets have regarded as endowed with so much grace and beauty, and living in luxurious ease, is but a fine lady octopus after all. Turn her out of her handsome residence, and, instead of the fairy skimmer of the seas, you have before you what Mr. Mantalini would call a "dem'd damp, moist, unpleasant body," like that of her weird and sprawling relative. The Paper Nautilus has been regarded as the analogue of the snail, which, like it, secretes an external shell for the protection of its soft body; and the octopus as that of the garden slug, which, having organs like those of the snail, as the octopus has organs like those of the shell-bearing argonaut, has no shell. The Cuttles and Squids may be compared to some of the sea-slugs, as Aplysia and Bullcea, and to some land-slugs, as Parmacella and Limax, which have an internal shell. $\dagger$ 
The female octopus not being furnished with a shell, none of her arms are modified in form, like those of the argonaut, for the purpose of secreting and holding one. The male octopus, also unlike the male argonaut, is as large as the female, but may easily be distinguished from her by his having numerous tubercles and papillæ on the skin, which become very prominent when he is irritated or excited. D'Orbigny, not recognizing this peculiarity as sexual, regarded it as a specific distinction, and made of the male octopus a separate species, O. tuberculatus.

Having briefly explained the generic history and relationship of the octopus, I propose to introduce to the reader some members of the family with whom I have been on friendly terms. A former casual acquaintance with some of their kinsfolk at the sea-side, ripened, afterwards, into a close and prolonged intimacy with them in their home; and I thus obtained an insight of their habits and peculiarities, many of which are very curious and interesting. 


\section{CHAPTER II. \\ OCTOPODS I HAVE KNOWN.}

THE first Octopus whose habits and mode of life I had opportunities of observing in captivity, was one exhibited in the Aquarium at Boulogne in September 1867 . It was the prominent subject of conversation at the tables ${ }^{p}$ hotte of all the hotels there, and almost the first words addressed to a new-comer were, "Have you seen the devil-fish?" It was but a miserable little imp, only half matured in diablerie, and so persistently concealed itself by burrowing in a considerable depth of shingle, that all that could generally be seen of it was a portion of one of its arms waving gently in the water. But perhaps this was quite as well as if more had been visible, for it left a great deal to the imagination, and was also profitable to the proprietor, because people repeated their visits daily in hope of obtaining a better view of it. The privilege of privately inspecting it was several times accorded to me, and I then first witnessed many of the movements, ways, and habits of this animal, with which I have since become familiar.

The first octopus received at the Brighton Aquarium was caught in a lobster-pot at Eastbourne in October 1872 , and great was the joy that reigned in "London-by-the-sea." For in the state of public feeling then existing, an aquarium without an octopus was like a plum-pudding without plums. Share-holders might construct a handsome building, and stock its magnificently gigantic tanks with a variety of most interesting fishes, but fashion and public 
opinion demanded of them a "devil-fish," and if they were unable to exhibit one, all other attractions were disregarded. The new octopus became "the rage." Visitors jostled each other, and waited their turn to obtain a peep at him-often a tantalizing exercise of patience, for the picturesque rock-work in the tanks provided so many hiding places, that, until these were partially filled with cement, the popular favourite only occasionally condescended to show himself. Poor fellow ! his career was short, and his end sudden and shocking. During the interregnum between the death of my friend John Keast Lord, and the appointment of a successor to him in the curatorship, it became necessary to clean out a tank in which were some "Nurse-hounds," or "Larger spotted dog-fishes," Scyllium stcllarc. No hostility between them and the octopus being anticipated by their attendant, they were temporarily placed with it, and, for a while, they seemed to dwell together as peaceably as the "happy fanily" of animals that used to be exhibited in a travelling cage at the foot of Waterloo Bridge; the octopus usually remaining within the "Cottage-by-the-sea" which he had built for himself in the form of a grotto of living oysters, and the dog-fish apparently taking no notice of him. But one fatal day- the 7 th of January, i 873 - the "devil-fish" was missing, and it was seen that one of the "companions of his solitude" was inordinately distended. A thrill of horror ran through the corridors. There was suspicion of crime and dire disaster. The corpulent nurse-hound was taken into custody, lynched and disembowelled, and his guilt made manifest. For there, within his capacious stomach, unmutilated and entire, lay the poor octopus who had delighted thousands during the Christmas holidays. It had been swallowed whole, and very recently, but life was extinct.*

It is interesting to look back to the beginning of things, to trace

* "The dear devoured one," as a local journal called it, was at once immersed in methylated spirits. The dog-fish was stuffed. Both are still preserved at the Aquarium. 
the progress of our knowledge of them, and to note the development of our ideas concerning them, and the change of sentiment with which they are regarded. I saw lately a dead octopus, which had acquired "a very ancient and fish-like smell," kicked about by boys in the carriage-way of a Brighton street without attracting attention; but, so strongly was public interest excited by "the dog-fish and octopus case," that the press teemed with paragraphs on the "tragic fate of an octopus," and even in the London daily papers appeared brilliantly written and kindly sympathetic leaders on the subject. The concluding paragraph of one was as follows :- " Thus was an end put to a most distinguished and useful life. Octopuses doubtless die every day, but seldom has there been an octopus who will be so much missed as the octopus at Brighton." This was prophetic. For nearly two months the loss was not repaired. Golden tench from Aldermaston, trout from Byron's Newstead, red mullet and other rarities, could not suffice to fill the void. At length, on the ist of March, a fine specimen was received from Mevagissey, Cornwall. Then Brighton was herself again, and the officials of the Aquarium jubilant. As the spring advanced, facilities for procuring these animals increased. Specimens were sent from the French coast, and othersa dozen at a time-from the Channel Islands, until it appeared not impossible that the octopus would become so abundant, that the very dog-fishes would be satiated with them, like the apprentices with salmon," and parodying the school-boys' grace

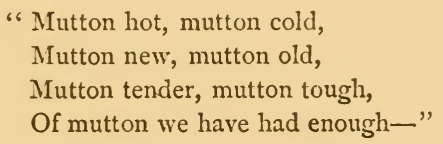

would refuse to eat one oftener than once a week.

* The story of apprentices stipulating with their masters that they should not be required to eat salmon on more than a specified number of days in a week-a familiar illustration of satiety producing not only indifference but 
Since then, the Brighton Aquarium has only once been without an octopus; and although the popular chief of curiosities in a marine vivarium has doubtless passed the zenith of his greatness, he still holds an honoured place amongst the "past masters" of the tanks.

After the publication in the "Times," "Land and Water" and other papers, of my notes of observations of the habits of the octopus in confinement, I was favoured with several private letters on the subject; some of them from strangers giving me interesting information concerning it, derived from their own experience, and others requesting me to decide between adverse opinions based respectively on the florid conceptions of the novelist, and the scarcely less romantic, though truthful, description of the naturalist.

Articles and paragraphs on the same topic, also, not infrequently appeared about that time, in daily and weekly papers; of one of which the following is a portion :- "It is much to be hoped that as time and observation serve, Mr. Lee will give to the public a paper devoted to a close scientific examination of Victor Hugo's description of the devil-fish, so as to settle to the minutest points wherein it is true to nature, and wherein the novelist has deviated from the severity of fact." I confess the thought never before occurred to me to dissect the author's description of the frightful animal he depicts, because I have always regarded it as an accumulation of intentionally fanciful and ingenious exaggerations, which, with great melodramatic power, he succeeded in combining into an embodiment of mysterious horror. But I accepted the suggestion, and have incorporated in a comparative analysis of M. Hugo's stirring romance, a description of the organization of

disgust-is probably, like many other illustrations, over-drawn, and not wholly correct in its representation. For if, as has been suggested, the salmon the youths objected to were often kelts, salted or fresh, their protest is hardly to be wondered at. No trace of such a stipulation has, however, been found in any old indentures. 
the octopus or pieuvre, and of those of its habits to which he alludes. Other circumstances of its life-history, which did not come within the scope of his work, are treated of in separate chapters. Before critically reviewing his narration of the incidents referred to, it may be desirable to give a brief summary of the plot of the story of which they form a part, and which made the octopus famous. 


\section{CHAPTER III.}

"THE TOILERS OF THE SEA."

ThE scene of "Les Travailleurs de la Mer" is Guernsey, and the two characters brought most prominently forward are Gilliatt and Clubin. Gilliatt was a man not much liked. He avoided company, neither drank, smoked, chewed, nor snuffed; and lived in a house which, if not then haunted, was suspected of having formerly been so. None, however, could deny that he was a thorough seaman, a successful fisherman, a skilful pilot, and an expert swimmer; and subsequent events proved him to possess dauntless courage, pertinacious determination, a soft heart, and chivalrous spirit. Clubin was in every moral quality exactly the reverse. He had the reputation of being a man of severe probity, strictly religious, and of unsurpassable integrity; and thus was appointed master of a little steamer named the "Durande," which traded between Guernsey and St. Malo, and belonged to a Monsieur Lathierry. But although Clubin had gained the good opinion of his neighbours by his cunning and adroitness, he was a consummate hypocrite, and an unscrupulous scoundrel. A former partner of Lathierry, named Rantaine, had robbed their joint cash-box ten years previously of a hundred thousand francs, fifty thousand of which, of course, belonged to Lathierry. Nothing had been seen or heard of him since he absconded, until one day Clubin caught sight of him in St. Malo, watched him enter the shop of a money-changer, and receive three bank-notes of roool. each $(75,000$ francs $)$, and, at once surmising that they were the proceeds of the embezzlement, determined to possess them. $\mathrm{He}$ prepared his plans carefully, obtained with some difficulty a 
revolver (then a novelty in fire-arms), ascertained that Rantaine intended to escape from France in a vessel, the captain of which had agreed to send a boat ashore for him; and just as he was about to embark, after killing a coastguardsman to prevent his giving an alarm, presented the revolver at his head, and demanded "restitution," as he called it, of the plunder. An altercation ensued; but the formidable weapon gave its owner superiority, and Rantaine was made to toss to his opponent from a distance the three bank-notes, enclosed in an iron tobacco-box, and was then allowed to depart. Clubin had already decided on the measures he would adopt to enable him to enjoy his ill-obtained wealth in a foreign country, without exciting a suspicion of his evil deed. The "Durande" was to leave St. Malo the next day, on her return trip to Guernsey with passengers and cargo. Weather-wise mariners predicted a fog, and urged Clubin not to leave port; but he resolutely disregarded their advice, and put to sea, placed a bottle of brandy in the secret hiding-place used by his tippling steersman, who fell into the trap and got drunk; and when the expected fog came on, the austere and puritanical captain sent him forward with a reprimand, and, to the admiration and satisfaction of the passengers, took the helm himself, and went on at full steam for his destination. There were some on board who thought he was running a great risk in not slackening speed; and one passenger, a Guernsey man, felt sure that they were not in their right course, and told the captain that more than once, when the fog had lifted a little, he had recognised the land a-head as a point called the "Hanois." But Clubin kept straight on; for this was just the spot where he had deliberately determined to run the vessel ashore. In a few minutes she struck. The boat was got over the side and launched, passengers and crew took their places in her, and then all waited for the captain. But the devoted man refused to leave his vessel. $\mathrm{He}$ would do his duty to the last, and sink with her; and so, finding persuasion useless, they were obliged to put off without him; 
some weeping for sorrow, and all regarding him as an hero, and the most honest man that ever sailed the seas. Here, then, was Clubin, alone in the very position he desired, with 75,000 francs in his pocket, and having succeeded, whilst perpetrating all his villany, in gaining, instead of losing, the esteem of his fellow-men. He would give the over-crowded boat time to get away-to be lost, perhaps, with all on board. The short mile to the shore would be nothing for a swimmer like him to traverse; he would soon gain the land, conceal himself for a time, and then quit the neighbourhood; whilst he would be supposed to be dead, and would leave an honoured name behind him. He waited, and exulted over his success. Suddenly, through a rift in the fog, a huge object attracted his horrified gaze. He had been deceived in his position. Instead of having run the "Durande" on the Hanois, before him was the formidable "Rocher Douvres"-the "ManRock." Hideous and instant is the change in his conditionfive leagues of sea, instead of one mile, between him and the main! To swim that distance is impossible; he can never reach the land. Death from cold and hunger stare him in the face. His 75,000 francs will not here purchase him a crust of bread. His only hope now lies in his being seen by some passing ship, and eagerly he looks to seaward. A sail appears-approachesthe vessel is a cutter. But those on board will never see him where he stands. If he can but reach the rock he will no doubt be perceived. There is not a minute to lose; he will try; two hundred strokes will do it, and he will be saved. He throws off all his clothes, buckles around his naked body the leather belt in which is the tobacco-box containing the notes, and plunges into the sea. He touches the bottom, grazes for a moment the side of a submerged rock, then makes an effort to rise to the surface. At this instant he feels himself seized by the foot.

In this horrible situation the author leaves him for a time, and follows the course of events on the island which the miserable 
wretch was destined never to reach. The boat was seen by a small coaster, and its occupants taken on board, and conveyed to St. Peter Port. The rescued crew and passengers of the "Durande" quickly spread the tidings of the disaster, which fell with crushing effect on her owner, Lathierry; the whole blame was laid on Tangrouille, the drunken steersman, who was imprisoned, and the magnanimity of Clubin was everywhere extolled. The master of a cutter, which arrived a few hours after the landing of the saved people, reported that, hearing the bellowing of the oxen which were a portion of the little steamer's freight, and the fog having dispersed, he had borne down to the wreck and approached near enough to be certain that there was no one on board; and consequently an opinion was expressed that the heroic captain had been taken off by some sloop or lugger belonging to Granville or St. Malo, and his return was hourly expected. The steamer had broken her back, said the cutter's master, but the engine appeared not to be damaged. It was suggested that it might be possible to preserve it; but the seaman shook his head, and gravely replied that "The man did not exist who could go there and remove it." Renewed hope roused Lathierry from his stupor, and he exclaimed, with a solemn oath, that he would give his daughter, Deruchette, in marriage to the man who would perform the feat. Gilliatt had long secretly loved the girl, and he determined if possible to achieve the task, and thus to win her. He quietly stole away from the crowd, and the same night, alone and unaided, got under weigh his fishing craft, which he had won as a prize for seamanship in a regatta, and proceeded to the wreck. After much toil and endurance of hardship for more than two months, he succeeded in extricating the engine and getting it on board his boat: His work completed, he had only to wait for the tide to return in triumph with his prize. But he was faint with hunger. He had long since exhausted the stock of provisions he had brought with him, and had subsisted on the molluscs and crustaceans he had been able 
to find on the rocks; and, now, it became necessary to search for one more meal before his departure. Profiting by the low tide, and taking his knife between his teeth, he descended, by the help of hands and feet, the steep escarpment into a pool. The water came up to his shoulders. During his search for lobsters, crayfish, and crabs, he espied a cavern, the arched portal of which was partly uncovered. He entered. A fine crab, frightened at his approach, escaped into a horizontal fissure in the rock. He thrust his hand into the crevice, and suddenly felt himself seized. Something slender, rough, adhesive, chilling, and living, was twisting itself in the gloom around his naked arm. It proved to be one of the limbs of a pieuvre (octopus), or "devil-fish," and he had a terrible fight with the creature. It will be convenient to consider in detail the particulars of the combat after finishing our epitome of the narrative of which it fills the most remarkable chapters. Gilliatt, after a desperate struggle, succeeded in cutting himself free, and in killing the animal with his knife; and then, panting with his exertions, turned to leave the place where he had encountered so dangerous a foe. As he did so, something which startled him caught his eye. He fancied he saw at the back of the cavern a face which laughed at him. $\mathrm{He}$ approached, and stooping down, found it was a human skull, with the rest of the skeleton. It was surrounded by a multitude of crabs, but they were dead and their shells empty. It was the larder of the "devil-fish"; the monster had eaten the crabs; the crabs had eaten the man. There were no articles of clothing to be seen ; but, scraping away the crab-shells beneath which the skeleton was half buried, Gilliatt perceived around the vertebral column a leather belt, which had evidently been buckled about the body of the man before his death. The leather was wet, the buckle rusty; so Gilliatt cut the girdle with his knife. It contained an old iron tobacco-box, which he forced open, and found in it three bank-notes of $£ \mathrm{r} 000 \mathrm{each}(75,000 \mathrm{francs})$, and twenty guineas in gold. He examined the belt more closely; and there, traced in indelible 
lithographic ink, were the words, "Sieur Clubin." The skull, the bones, and the belt were all that remained of the robber ard hypocrite: the "devil-fish" had held him under water and drowned him; the crabs had eaten him.

Gilliatt started on his return passage to Guernsey in joyful certainty that he had earned the fulfilment of his wishes. Dernchette would be his wife. He had saved the engine of her father's vessel, and, more than that, had recovered the old man's stolen fortune. True to his natural shrinking from observation, he timed his voyage so that he arrived in port after dark, moored his sloop with her cargo of machinery to the old ring in the harbour wall to which the "Durande's" cable used to be made fast, and then, without announcing his return to anyone, retired to a nook overhung with brambles and ivy, where he had often watched for hours-himself unseen, and his love unsuspected-the house where dwelt the mistress of his heart, and the garden in which she often walked. Near him, at the side of one of the paths, was a rustic seat. As he gazed fixedly on the windows of her chamber, and thought rapturously of his future happiness, Deruchette herself left the house and came towards him. She sat down on the bench, in his full view, and with pensive, meditative air, remained motionless, as if in a dream. The thought of speaking to her never entered his head. He saw her, was near her-that was enough for him for the moment. A sound of approaching footsteps roused her from her reverie, and him from his ecstasy. It was the young rector, the Rev. Ebenezer Caudray, who had sought her to make her an offer of marriage before leaving for England on the following morning. Unhappy Gilliatt was a witness of his pleadings, her yielding, their betrothal and embrace.

Meanwhile Lathierry had seen from his window the funnel of the "Durande" standing at the old moorings; and, scarcely believing his eyes, rushed to the harbour bell, and rang it long and violently. Amongst those who appeared was Gilliatt, who, accompanying him to his home, laid before him the bank-notes and 
Clubin's belt. The old man, wild with joy, confirmed his offer of his daughter's hand to the man who had so nobly won his gratitude. But Gilliatt, to his astonishment, refused her: he knew that her affections were pledged to another, and determined in his own mind that she should marry the man of her choice. The next morning he met the lovers, and, with feverish haste, insisted on the immediate performance of the marriage ceremony; dragged them to the church, where, by an artifice, he substituted his rival for himself as bridegroom, and then hurried them on board the packet-boat which was just setting sail. His work accomplished, the desperate man locked up his house, and strode along the shore to a point of land close to which the vessel bearing Ebenezer and Deruchette must pass. At its extremity was a kind of "lovers' seat," called the "Chaise Gild-Holm'-Ur," covered by the sea at every tide, and near to which he had once rescued the young curé from drowning. There he sat, watching the craft, on the deck of which he could see the newly-wedded pair. It advanced nearer; the tide rose to his ankles:-it came opposite to him; the water reached his waist :-it passed : he watched and watched, and the tide rose and rose, until, as the vessel was lost to view, his head disappeared beneath the waves. 


\section{CHAPTER IV.}

THE DEVIL-FISH OF FICTION AND OF FACT.

BEARING in mind that the famous story of "The Toilers of the Sea" should be regarded as a romance and not as a scientific treatise, I will now endeavour to compàre the "devil-fish" of the author with the octopus of nature, and to indicate the points on which M. Hugo's representation of his "monster" is either substantially correct, partly true, or entirely unreal.

His description of the seizure of Gilliatt by the pieuvre shows that he was tolerably well acquainted with its habits, mode of attack, and external form. The half terrifying, half disgusting grasp of one of the animal's sucker-furnished arms, "supple as leather, tough as steel, cold as night;" the issuing of a second from the crevice, "like a tongue from out a mouth," and the successive application of a third, fourth, and fifth, to various parts of his body, whilst the other three retained firm hold of the rock, is powerfully, and, so far, correctly, depicted, if highly-coloured. And, although, when the octopus desires to alter the position of the suckers and to change its hold, it generally effects that by an instantaneous relaxation and renewal of the suction, by protrusion or retraction of the muscular piston within each, yet the gliding of the cupping discs over the surface of a man's wet skin is also in accordance with possibility, for I have tested it with a living octopus on my own arm. This will be easily understood by anyone who has watched the movements of the entomostracous parasites of fishes. The so-called river-louse, Argulus foliaceus, which infests all freshwater fishes, can run over their scales without loosening the 
hold of the two great suckers with which it is furnished; and others which, like Caligus and Lepeotheirus, have a water-tight carapace with a flexible margin, are able to move rapidly over the body of the fish in the same way.

In his relation of the manner in which the octopus captures its prey, the novelist is therefore substantially in accord with nature. The points on which he chiefly errs, are-

Ist. The structure, use, capability, and effect on its victim, of its arms and suckers.

2nd. Its general organisation.

3 rd. Its mode of progression when swimming.

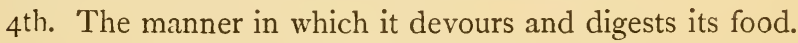

The arms are described as "encircling Gilliatt's whole body, cutting into his ribs like cord; . . forming a ligature about his stomach ; . . enfolding and constricting his diaphragm like straps; producing such compression that he could hardly breathe; . . his body almost disappearing under the folds of this horrible bandage; its knots garotting him, its contact paralysing him." The suckers are represented as being "like so many lips trying to drink your blood; . . they bury themselves to the depth of an inch in the flessh of their prisoner; . . on contact with them your muscles swell, the fibres are wrenched, and your blood gushes forth, and mixes horribly with the lymph of the mollusc."

The whole of this is fallacious. The arms of the octopus are not used as weapons of constriction, compression, or suffocation. They are eight radiating, supple, tapering thongs, in ordinary specimens from eighteen inches to two feet long, on each of which are mounted, in a double row, numerous sucking discs, which decrease in size towards the tips of the limbs, and act as so many dry cupping-glasses. There are normally about 240 of these suckers on each arm, making a total of about 1,920. I have counted more in some individuals. M. Hugo gives their number as "fifty on each arm, 400 in all ;" so on this point he very much understates his case. 
The cups themselves, by their internal mechanism for air exhaustion, and consequent pressure of the outer atmosphere, adhere firmly to any substance to which they are applied, whether stone, fish, crustacean, or flesh of man; but in the octopus they have no power to puncture or lacerate the skin, or to cause blood to flow. They are merely pneumatically prehensile organs, by which the animal's prey is caught and held; not by "harpooning," as the novelist supposes, but by their atmospheric adhesion to the surface of its body. In this genus the sucking discs are composed of a muscular membrane, the circumference of which is thick and fleshy, and in some species cartilaginous, but in all unarmed, and only adapted to secure close, air-tight contact with any object it may touch. When experimenting on the holding force of an octopus I have allowed it to fix its suckers firmly on my arm and the back of my hand,

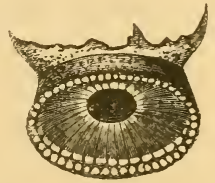

Fig. 2. Sucker of the (o. vulgaris). and by pretending to try to pull them away from its grasp have caused it to exert its utmost power of resistance and retention. The only effect of this has been that the vacuum produced an almost indistinguishable circular mark, corresponding with the edge of the larger discs, and not nearly so distinct as would be caused by the application of a glass tube to the skin, and the partial exhaustion of the air in it by drawing it from the other end by the mouth and tongue. In some of the Cephalopods the outer circle of the cups is a horny ring, sharply serrated or dentated around its edge ; and in others-for instance, Onychoteuthis - the centre of each cup is provided with a sharp, strong hook, capable of being extended or sheathed, like the claws of a cat, which is plunged deeply into the flesh of slippery prey for the better security of its hold; but the cuttle-fishes thus furnished are, unlike the octopus, habitually swimmers, instead of rock-crawlers. The sessile arms of the octopods are considerably longer than those of the decapods, or ten-armed cuttle-fishes; but the latter 
have, in addition to the eight corresponding limbs, two long tentacular arms, which, in some genera, are marvellous in the perfection of their compound apparatus for securing and holding a struggling captive. This arrangement is well suited to their habits and mode of life. Animals purely swimmers, and which hunt and overtake their prey by speed, would be impeded by having to drag after them a bundle of lengthy appendages trailing heavily astern. But a long reach of arm is an advantage, instead of a hindrance, to the octopus ; for, although it can swim on occasion, its ordinary habit is, either to rest suspended to the side of a rock, to which it clings with the suckers of several of its arms, in the position shewn in the frontispiece, or to remain lurking in some favourite cranny; its body thrust for protection and concealment well back in the interior of the recess; its bright eyes keenly on the watch ; three or four of its limbs firmly attached to the walls of its hiding place-the others gently waving, gliding, and feeling about in the water, as if to maintain its vigilance, and keep itself always on the alert, and in readiness to pounce on any unfortunate wayfarer that may pass near its den. To small fish, crustacean or mollusc, the slightest contact with even one of those lithe arms is fatal. Instantaneously as pull of trigger brings down a bird, or touch of electric wire explodes a torpedo or a mining fuse, the pistons of the series of suckers are simultaneously drawn inward, the air is removed from the pneumatic holders, and a vacuum created in each ; the victim strives to escape; a further retraction of the central part of the disc makes all secure; and, as arm after arm, containing a perfect mitrailleuse of inverted air-guns, takes horrid hold, battery after battery of them is brought to bear, and the pressure of the air is so great that nothing can effect the relaxation of their retentive power but the destruction of the air pump that works them, or the closing of the throttle-valve by which they are connected with it.* 
Desiring to have a better view than I had previously been able to obtain of that which follows the seizure of a crab by an octopus, I fastened one to a string, by which an attendant was to lower it in the water close to the glass, whilst I stood watching in front. The crab had hardly descended to the depth of two feet before an octopus for which it was not intended, and which I had not observed (so exactly had he assumed the hue of the surface to which he clung), shot out like a rocket from one side of the tank, opened his membranous umbrella, shut up the suspended crab within it, and darted back again to the ledge of rock on which he had been lying in ambush. There he held on, with the crab firmly pressed between his body and the stone work. As this was not what I wished, I directed my assistant to gently try to pull the bait away from him. As soon as he felt the strain, he took a firm grasp of the rock with all the suckers of seven of his arms, and, stretching the eighth aloft, coiled it round the tautened line, the suckers actually closing on the line also, as a caterpillar's foot gripes a thin twig, or a cobbler's leather pad folds round his thread when he is making a wax-end. It then became a game of "pull devil, pull baker," and the "devil-fish" won it. Noticing several jerks on the string, I thought at first they were given by the man overhead, and told him not to use too much force; but he called out, "It's not me, sir, it's the octopus : I can't move him; and he's pulling so hard that, if I don't let go, he'll break the line." "Hold on, then, and let him break it," I replied. Tug ! tug ! dragged the tough, strong arm of the octopus; and at the third tug the line broke, and the crab was all his own. The twine was that used for mending the seine net, and was therefore not particularly weak.

Although this experiment furnished a fresh illustration of the holding power of an octopus, it had not taught me exactly that which I wanted to know. I wished to be underneath that umbrella with the crab, or (which was decidedly preferable) to be able to see what happened beneath it without getting wet. My plan, therefore, was to procure the seizure of the crab against the 
front glass, instead of against the rockwork. Our next endeavour was successful. A second crab was so fastened that the string could be withdrawn if desired, and was lowered near to a great male octopus, who generally dwelt in a nook in the west front corner of the tank. He was sleepy, and not very hungry, and required a great deal of tempting to rouse him to activity; but the sight of his favourite food overcame his laziness, and, after some demonstrative panting, puffing, and erection of his tubercles, he lunged out an arm to seize the precious morsel. It was withdrawn from his reach; and so, at last, he turned out of bed, rushed at it, and got it under him against the plate-glass, just as I desired. In a second the crab was completely pinioned. Not a movement, not a struggle was visible or possible: each leg, each claw, was grasped all over by suckers-enfolded in them-stretched out to its full extent by them. The back of the carapace was covered all over with the tenacious vacuum-discs, brought together by the adaptable contraction of the limb, and ranged in close order, shoulder to shoulder, touching each other; whilst, between those which dragged the abdominal plates towards the mouth, the black tip of the hard, horny beak was seen for a single instant protruding from the circular orifice in the centre of the radiation of the arms, and, the next, had crunched through the shell, and was buried deep in the flesh of the victim.

The action of an octopus when seizing its prey for its necessary food is very like that of a cat pouncing on a mouse, and holding it down beneath its paws. The movement is as sudden, the scuffle as brief, and the escape of the prisoner even less probable. The fate of the crab is not, really, more terrible than that of the mouse, or of a minnow swallowed by a perch; but there is a repulsiveness about the form, colour, and attitudes of its captor which invests it with a kind of tragic horror.

In the next chapter the author writes :-

"To believe in the existence of the pieurre one must have seen it. Compared to it the ancient hydras were insignificant. Orpheus, Homer, and Hesiod 
imagined only the chimæra :-Providence created the devil-fish. If terror was the object of its creation, it is perfection.

"The 'pieuvre' has no muscular organisation, no menacing cry, no breastplate, no horn, no dart, no tail with which to hold or bruise, no cutting fins, or wings with claws, no prickles, no sword, no electric discharge, no venom, no talons, no beak, no teeth. . . . . It has no bones, no blood, no flesh. It is soft and flabby. It is an empty flask; a skin with nothing inside it. Its eight tentacles may be turned inside out, like the fingers of a glove. It has a single orifice, which is both vent and mouth. The same opening performs both functions."

So says the novelist. The naturalist knows that it has a complete and perfect muscular organisation; muscles which serve to retract and depress the funnel, bundles of strong muscles passing along the arms and branching to each of the suckers, within which other fasciculi of muscular fibres converge from the circumference to the centre, and by their contraction produce the vacuum which gives to the animal its power of adhesion,-muscles all over its body, and a mass of muscles of such strength to work the powerful beak, that if anyone, believing the fictionist, were to place his finger in the small circular orifice in the centre of the base of the arms, he would possibly learn practically that it is not "an empty flask with nothing in it." A sharp nip might perhaps teach him that it has not only muscles, but a mouth and head also. For just within the oral cavity lie, retracted and hidden, but ready for use when wanted, a pair of horny mandibles which bite vertically, like the beak of a parrot or turtle, except that the lower mandible is the longest and overlaps the upper, and are so hard that they can not only tear the softer

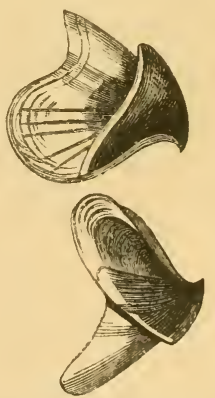

Fig. 3. Mlandibles of Octopus. animals the octopus is able to catch, but also break up the shells of lobsters, crabs, and mussels, which are its usual food. The head contains a brain, from which arises the system of nerves; and the animal has a sense of smell, 
and organs of hearing and taste, besides those which are apparent on its exterior, namely, of sight and touch. Instead of having "no blood," it is furnished with a complete circulatory apparatus consisting of one systemic and two branchial hearts, arteries which distribute the blood through all parts of the body, and a system of veins or canals by which it returns towards the gills, of which breathing organs the animal has two-one on each side. By the alternate expansion and contraction of the bladder-like mantle-sac-an action resembling that of a pair of bellows-the water is pumped into contact with these gills, which convey to the blood the oxygen contained in it; and when its life-giving, purifying gas has been extracted from it, it is expelled by the muscular, valved funnel, or syphon tube, which has also another function, to be

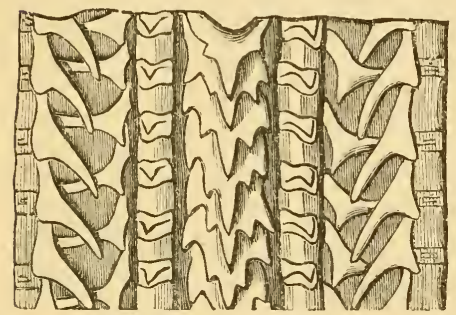

Fig. 4. Tongue of the Octopus (O. zulgaris). Magnified 12 diameters. presently described. Far from being "a skin with nothing inside it," from the beak and mouth (within which is a tongue like a rasp, having recurved spines or teeth) is continued the alimentary canal, œsophagus, crop, gizzard, stomach, and intestines; and within this so-called "empty pouch" are also the liver, and the organs of reproduction and respiration. The "tentacles," or arms, cannot be "turned inside out like the fingers of a glove." On making a section across one of them, it will be seen that it is composed of close muscles, the fibres of some of which run longitudinally, and others transversely. The arm, therefore, is more like the strong flexible lash of a stout hunting whip than the finger of a glove, and is solid, except that it has a perforation along the centre of its axis for the lodgment of its nerve and artery. 
The author accurately describes the action and movement of the octopus, and its utilisation of its eight arms when crawling at the bottom, or on ledges of rocks. The globose body is then turned upward, the mouth downward, and the arms sprawl along, and by grappling some fresh object drag the body after them. But he is mistaken concerning its mode of progression when swimming. After stating that in swimming, it, so to speak, sheaths and draws close together its arms, which is quite true, he continues :-

"Figure to yourself a sleeve sewn up with a fist in it. This fist, which is the head, pushes through the water, and advances with an undulating movement."

That which M. Hugo supposes to be the head is the body of the animal. He appears to have received this impression from Pliny,* who writes:-_ "The head, which is directed obliquely when they swim, is, in the living animal, hard and distended like a balloon." The cuttle-fishes, and the octopus amongst them, propel themselves rapidly backward, when swimming, by the forcible expulsion from the funnel, in sudden and frequent jets, of the water drawn in at the branchial, or gill openings. Thus the organs of respiration become those of locomotion as well, and the funnel has also another function, being the orifice from which the excreta are expelled. It has been asserted by various writersand the statement has been repeated by many able naturaliststhat the octopus swims by vigorous flappings of the expanded membrane which extends from the sheath of the mouth along the arms, and connects the bases of the latter like the web of a duck's foot. It is true that this sometimes, though very rarely, takes place, but its proper and usual mode of progression is with the body in advance, the arms closely packed together, and directed backward horizontally in its wake, whilst the jets of water, pumped out at frequent intervals from the funnel, propel it at a considerable speed. I have had opportunities of watching the

* "Naturalis Historix," lib. ix., cap. 29. 
habits of at least a hundred individuals of this species, yet have only three or four times seen them progress, when swimming, by powerful contraction of the web-like membrane, and then but for

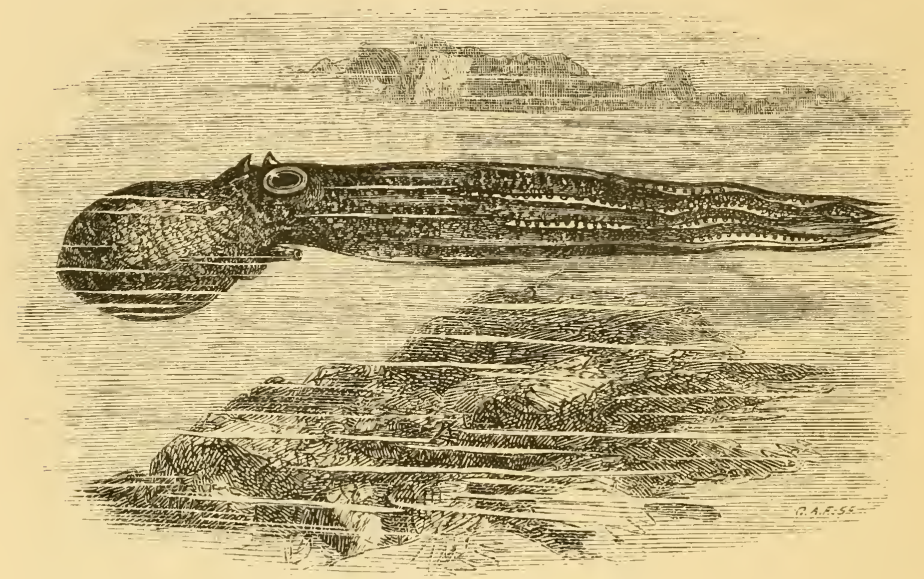

Fig. 5. The Octopus swimming.

a very short distance. Still less frequently does the octopus reverse its usual course; but I have twice seen one swim with its arms extended in advance of it, by bending the syphon tube beneath its body so as to present the orifice in a direction exactly contrary to its normal position.

M. Hugo forcibly refers to the remarkable property of rapidly changing its colour possessed by this animal. He writes:--

"Its under surface is yellowish ; its upper, earthy. Its dusty hue can neither be imitated nor explained : it might be called a 'a beast made of ashes, which inhabits the water.' Irritated, it becomes violet. It is a spider in form, a chameleon in coloration."

When quiescent, the general tone of colour of the octopus is a mottled brown, but it assimilates itself as much as possible to the rock to which for the time it may be holding. The moment it 
commences to swim it assumes a deeper hue, which usually becomes a dark, dingy red, but sometimes tends to purple. Mr. Darwin, in his delightful "Journal of Researches made during the Voyage of H.M.S. Beagle," mentions his having noticed its endeavour to escape detection by the use of this chameleon-like power of changing colour so quickly as to cause it to vary with the nature of the ground over which it passes. This is effected in the same manner as the similar mutation of colour in the chameleon. Through the thin and transparent outer skin are visible cells in the inner layer beneath it, which contain pigmentmatter of yellow, blue, red, and brown. By the contraction and expansion of the cells, prominence is given to one or another of these colours, at the will of the owner; and not only do the spots appear, and fade, and alternate in position, but, like human beings, the octopus turns pale when exhausted, and flushes red under the influence of anger or excitement. A curious play of colour, which I have elsewhere compared with the flashing and dying out of sparks in tinder, often takes place on the skin of the cephalopods by the continued action of the pigment cells, long after the death of the animal. The ancients were well acquainted with this colour-changing habit of the octopus. Aristotle mentions it, and Oppian describes it as follows :-

"All fishers know the changing prekes' deceit, How, clung to rocks, when coming dangers threat New forms they take, and wear a borrowed dress, Mock the true stone, and colours well express. As the rock looks they take a different stain, Dapple with grey, or branch the livid vein.

Thus they, concealed, the dreaded danger shun

By borrowed shapes obscured, and lost in seeming stone."

It was also frequently referred to by other writers. Athenæus quotes Theognis of Megara as saying in his Elegies :-

" Remark the tricks of that most wary polypus, Who always seems of the same colour and hue As is the rock on which he lies ;" 
and Ion the tragedian, who wrote in his "Phœnix":-

"I hate the colour-changing polypus

Clinging with bloodless feelers to the rocks."

It was also the subject of a maxim equivalent to our "When you're at Rome, do as Rome does." A proverb cited by Clearchus runs thus:-

"My son, my excellent Amphilocus,

Copy the shrewd device o' the polypus

And make yourself as like as possible

To those whose land you chance to visit."

M. Hugo poetically alludes to the phosphorescent glow said to be emitted by the octopus in the dark :-

"By night, and especially in the rutting season, it is phosphorescent. Awaiting its spouse, it beautifies, kindles, illuminates itself; and, from the height of some rock, it may be perceived in the profound darkness beneath, blossoming in wan irradiation-a spectre sun."

I have never been fortunate enough to witness the exhibition of this phosphorescence by the living octopus, although in dead specimens, as is the case with other marine animals, it becomes apparent as soon as decomposition has commenced; but D'Orbigny mentions it, and Mr. Darwin says, "I observed that one which I kept in the cabin was slightly phosphorescent in the dark." * No doubt concerning this can, therefore, exist; for a more competent observer, or more accurate recorder of facts than Mr. Darwin, never put pen to paper.

In his description of the manner in which the devil-fish absorbs its victim, the author of "The Toilers of the Sea" releases his ardent imagination from the few restraining ties by which it was bound to reality. He writes :-

"You enter into the beast, the hydra incorporates itself with the man: the man is amalgamated with the hydra. You become one. The tiger can only devour you ; the devil-fish inhales you. He draws you to him, into him ; and,

* Voyage of the Beagle; p. 8. 
bound and helpless, you feel yourself slowly emptied into this frightful sac, which is a monster. To be eaten alive is more than terrible ; but to be drunk alive is inexpressible."

M. Hugo fortunately gives us the means of estimating the size of the body of the octopus which attacked Gilliatt. He tells us that its arms were "nearly a metre (thirty-nine inches) long." None of quite so great dimensions have, I believe, been found in the English Channel, but it is not impossible that such exist. Granting this, the body of such an octopus would not be very much larger than a soda-water bottle or a Florence-flask, such as olive-oil is sold in : and so the "horrible bag, which is a monster," and into which you are to be inhaled and drawn alive, is but a small affair after all. The plain truth is, that the octopus and other cephalopods obtain and eat their food very much like the rapacious birds. They are the falcons of the sea. Some of them, like Onychoteuthis, strike their prey with talons and suckers also; others, like the octopus, lay hold of it with suckers alone; but they all tear the flesh with their beaks, and swallow and digest their food in as unromantic a fashion as does hawk or vulture.

But it is when the author indulges in what he is pleased to call "philosophical meditation" on such animals that he arrives at the highest point of hyperbolical mystery. He tells us :-

"They are the chosen forms of evil. What are we to do in presence of these blasphemies of creation against itself?... The possible is a formidable matrix. Mystery concretes itself in monsters. Portions of shades come forth from this block, the perpetual ; tear themselves, divide themselves, roll, float, condense, borrow from the ambient blackness, undergo unknown polarizations, assume life, compose for themselves who can tell what forms with obscurity, what souls with miasma; and issue from them larvæ, athwart the course of vitality. They are as the darkness converted into beasts. Of what use, for what purpose, are such creatures?-relapse of the eternal question! These animals are phantoms as much as monsters. They are the amphibiæ of death, the visible extremities of black circles. They mark the transition of our reality to another."

To analyse this is beyond my powers. One can only wonder what it all means. The language is sententious, and would, no 
doubt, be impressive if it were not incomprehensible. It reminds one of Mr. Maccabe's "Welsh sermon," which, delivered with solemn earnestness, rolls forth in grandly sonorous tones, but has not a word of Welsh or sense in it ; or of the "nonsense-problem" which Mark Twain says was propounded to him by Artemus Ward, and which seemed so full of thought and so clearly put that he blamed his "wooden head" because he got into a hopeless tangle over it, until he found he had been entrapped into pondering over "a string of plausibly worded sentences that did not mean anything under the sun."

Let us now take evidence concerning the dimensions to which the octopus is known to attain, and the degree in which it may be regarded as dangerous to man.

An octopus from our own coasts having arms two feet in length may be considered a rather large specimen; and Dr. J. E. Gray, who was always most kindly ready to place at the disposal of any sincere inquirer the vast store of knowledge laid up in his wonderful memory, told me that "there is not one in the British museum which exceeds this size, or which would not go into a quart pot, body, arms and all." The largest British specimen I have hitherto seen had arms $2 \mathrm{ft}$. 6 in. long.

If, however, the octopus seldom or never arrives at a length of arm of three feet on the northern coasts of France, we have sufficient evidence that it exceeds it on her southern borders, and along the Spanish and Italian shores of the Mediterranean.

M. Verany, of Nice, an able naturalist, mentions having seen an octopus which weighed $33 \mathrm{lbs}$. and measured three mètres from tip to tip of its outstretched arms. . This would make the length of each arm about four-and-a-half feet. A fisherman who noticed it affixed to the mole of the port of Nice had the hardihood to grasp it with his hands, and made himself master of it, though not without much difficulty.

Mr. Sylvanus Hanley, the well-known conchologist, and joint author with Professor Edward Forbes of their standard work 
on the British Mollusca, who passes every winter in Italy, has personally informed me that there are living in the harbour of Leghorn several octopods having arms at least four feet long, and as thick at their base as a man's wrist. They lie with their bodies squeezed into, and hidden in, crevices in the stonework of the mole and sea-wall, two or three of their arms extended and waving about in the water in readiness to seize passing prey, and the others holding fast to the blocks of stone. Mr. Hanley says that his son, who is a practised shore-hunter, and no coward, having frequent occasion, whilst in search of shells, to climb along a ledge of the rough masonry near the surface of the water, just beneath which was the lurking-place of one of these great creatures, was for some time afraid to pass the spot, in consequence of the animal's formidable appearance ; for, as he approached, it would thrust one or two of its disc-studded arms out of water, and stretch them towards him in a threatening manner, in its endeavours to reach him. The Italian divers and bathers are said to fear these creatures.

My deceased friend John Keast Lord gives in his book, "The Naturalist in British Columbia," some particulars of the dimensions attained by the octopus in North-Western America. He writes :- "The octopus, as seen on our own coasts (of England), although even here called a 'man-sucker' by the fishermen, is a mere Tom Thumb-a tiny dwarf-as compared with the Brobdingnagian proportions he attains in the sunny bays and long inland canals of Vancouver's Island, as well as on the mainland. These places afford lurking-dens, strongholds, and natural sea-nurseries, where the octopus grows to an enormous size, fattens, and wages war with insatiable ferocity on all and everything it can catch. The size, of course, varies. I have seen and measured the arm five feet long, and as large at the base, where it joins the central disc, as my wrist." $\mathrm{He}$ adds that the Indians, when spearing them for food, take care to keep them at a distance till they have stabbed them to death; knowing that if an octopus were once to 
get some of its huge arms over the side of the canoe, it could as easily haul it over as a child could upset a basket. But we know that a canoe is very crank, and easily upset.

I have often been asked whether an octopus of the ordinary size can really be dangerous to bathers. Decidedly "Yes," in certain situations. The octopus would not seize a man for the purpose of devouring him; nor do I believe that the act would be prompted by a deliberate intention to drown him, that his dead body might become an attractive bait for crabs, which are the animal's favourite food; but rather by an instinctive desire to lay hold on anything moving within reach. The holding power of its numerous suckers is enormous. It is almost impossible forcibly to detach it from its adhesion to a rock or the flat bottom of a tank; and if a large one happened to fix one or more of its strong, tough arms on the leg of a swimmer whilst the others held firmly to a rock, I doubt if the man could disengage himself under water by mere strength, before being exhausted. Fortunately, it can be made to relax its hold by grasping it tightly round the "throat" (if I may so call it), and it may be well that this should be known.

That men are occasionally drowned by these creatures is, unfortunately, a fact too well attested. In August, 1867, the Genow Gazette mentioned that a carter of Sampierdarena, who had gone to bathe near the reef of San Andria, was seized by an octopus, which, in spite of all his efforts, dragged him under water and drowned him. Not one of the bathers who witnessed the occurrence dared to go to the assistance of the unfortunate man.

Admiral Baillie Hamilton has kindly furnished me with some information on the subject. He tells me that in his time, many years ago, it was an understood thing that there existed amongst the rocks. of Gibraltar Bay an octopus of large size; and that during the last half-century one soldier at least of the garrison has been drowned whilst bathing there by being grasped under water by one of these "devil-fishes." 
Major Newsome, R.E., has also been so kind as to send me the following description of an incident which happened to himself.

"In the years $1856-7$," he writes, "I was stationed at East London, a landing place about 900 miles from the Cape, up the east coast of Africa;-I speak from memory, having no map at hand. It is a rock-bound coast with the exception of the river's mouth, which consists of a small space of sand. The landing is most dangerous, and, conducted in surf boats, hatched over, is only then practicable in very calm weather. The ordinary practice amongst the officers, both for comfort and saving of labour, is to bathe on the sea shore. Such was my custom each morning. There was one quadrangular cavity in the rocks which, at low water and in calm weather, formed a very desirable bath; but in rough weather, or at any time of tide except near about low water, it was unapproachable. At the best of times it was generally in a boil, and I have known a strong swimmer washed clean out of it on to the adjoining rocks, cut most grievously about the body by barnacles. Nevertheless, we mostly took a dip there when practicable, on account of the freshness of the water. At other times the plunge took place in. smooth pools left in the rocks by the receding tide, which, though not quite so fresh, yet formed a very acceptable bath. One morning I took a header into one of these pools, which was, perhaps, 20 feet long, 7 to 8 feet wide, and deep in the centre -8 or 9 feet. As I swam from one end to the other, I was horrified at feeling something around my ancle, and made for the side as speedily as I could. I thought at first it was only sea-weed; but as I landed, and trod with my foot on the rock, my disgust was heightened at feeling a fleshy and slippery substance under me. I was, I confess, alarmed, and so, apparently, was the beast on whom I trod, and whom, I suspect, I thereby discomfited, as he quickly detached himself and made again for the water. Some fellow-bathers, whom I hailed, came to my assistance, and with a boat-hook, on to which the brute 
clung, he was, eventually, safely landed. When extended he would have filled a hoop of five feet diameter. The grasp of an ordinary sized octopus holding to a rock would, I suppose, in lat. $30^{\circ}$, be not less than $30 \mathrm{lb}$. to $40 \mathrm{lb}$. The floating power of a man is between $5 \mathrm{lb}$. and $6 \mathrm{lb}$, and it takes a very strong swimmer to convey an ordinary fowling-piece, which weighs only $7 \mathrm{lb}$., across a river, dry. Had I not kept mid-channel, I believe it would have been a life-and-death struggle between myself and the beast on my ancle. In the open water I was the best man; but near the bottom or sides, which I could not have reached with my arms, but which he could have reached with his, he would, certainly, have drowned me."

Major Newsome has not over-estimated the holding-power of an octopus. One in the Brighton Aquarium was seen dragging towards it a huge stone, from $40 \mathrm{lb}$. to $50 \mathrm{lb}$. in weight. It is not uncommon for one to haul up to a ledge of rock, four or five feet from the bottom, two or three heavy oysters simultaneously; and it unfortunately happened in the early days of the Institution, and before precautions were taken to avert such accidents, that an octopus drew up, by night, the waste-valve of his tank, and let all the water run out of it ; thus, by his strength, like Samson at Gaza, bringing death upon himself and all his companions. 


\section{CHAPTER V.}

\section{THE OCTOPUS OUT OF WATER.}

UNTIL by the establishment of aquaria opportunities were furnished of observing the habits of the octopus in captivity, very little was known as to the truth or otherwise of the statement that it would sometimes voluntarily leave the water, and ramble on land in search of food. Professor Edward Forbes* says that, in the sudden falls, lasting not very long, of the sea-level, which occur from various causes in the bays of the countries in and around the Egean, this creature may be met with walking on the exposed shore; but he thinks it doubtful whether it ever wanders of its own choice above the usual water-mark.

Aristotle affirms that it comes out of the sea and walks in stony places; and Pliny tells of an enormous polypus (octopus) which at Carteia, in Grenada - an old and important Roman colony, near Gibraltar-used to come out of the sea at night, and carry off or devour salted tunnies from the curing depôts on the shore; and adds that the head of it, when it was at last killed, was found to weigh 7oolb. Elian records a similar incident, and describes his monster as crushing in its arms the barrels of salt fish to get at the contents. These old writers seem to have aimed rather at making their histories sensational than at carefully investigating the credibility or the contrary of the highly-coloured reports brought to them. They were, of course, gross exaggerations; but there is a substratum of truth in them; and in the proceedings of an octopus in the Brighton Aquarium we may recognise the living 
model of the bold, broad sketches from nature from which the old artists fancifully drew their showy but untruthful pictures.

In May, I873, it was found that some young lump-fish ( $C y$ clopterus lumpus, were mysteriously disappearing from one of the tanks. Almost daily there was a fresh and inexplicable vacancy in the gradually diminishing family circle, and morning after morning a handbill might have been issued :- "Missing ! Lost, stolen, or strayed, a young 'lump-sucker,' rather below the middle . size, and enormously stout ; had on a bright blue coat, with several rows of buttons on it, and a waistcoat of lighter colour. Whoever will give such information as shall lead to the discovery of the same, or produce satisfactory evidence of his death, will relieve the troubled minds of the curators!" "What on earth can have become of them?" "Where can they be?" were the questions each attendant asked in vain of another. If they had died they would have been found in the tank, for there were no crabs there that could have eaten them; they could not have burrowed in the shingle, for it was not deep enough; and, with their obesity of form, they could no more have leaped out of the tank than Mr. Wardell's fat boy in "Pickwick" could have jumped a fivebarred gate. Here was a puzzle! One by one they were lost to sight, as regularly and unaccountably as pair after pair of Lieutenant Charles Seaforth's breeches disappeared from his bedroom at Tappington, as related in the "Ingoldsby Legends."

One morning, however, Mr. Lawler, one of the staff, on going to count our young friends, found an interloper amongst them. "Who put this octopus in No. 27 tank?" he inquired of the keepers. "Octopus, sir? no one! Well, if he ain't bin and got over out of the next tank!" And this was just the fact.

The marauding rascal had occasionally issued from the water in his tank, and clambered up the rocks, and over the wall into the next one ; there he had helped himself to a young lump-fish, and, having devoured it, returned demurely to his own quarters by the same route, with well-filled stomach and contented mind. 
This was not very difficult for him to accomplish, for the partition between the two tanks is only about a foot above the surface of the water. Having accidentally, or otherwise, discovered that there was a preserve of live stock suitable to his palate next door, he paid frequent nocturnal poaching visits to it, and, after clearing up every remnant of his meal, regularly slunk home before daylight; until, like most criminals, becoming careless by frequently escaping detection, he, on the last occasion, indulged at suppertime in an inordinate gorge, and slept under his neighbour's porch, instead of going home to bed.

His return homeward at daybreak was caused by no intelligent fear of his keeper, but by a perfectly natural instinct inherited from his ancestors, namely, that of retiring during the day to his own favourite den or lurking-place, as an ogre is supposed to ensconce himself in his castle or cavern after having satiated his rapacious maw in a successful foray. For it must be remembered that the octopus is nocturnal in its habits, and ordinarily hides itself as much as possible during the day, shrinking from the light, which is apparently disagreeable to it: its wanderings in search of food, therefore, gererally take place at night.*

* A few days after the publication in Land and Water of my account of this occurrence, the following lines appeared in Fun. They were written by its editor, poor dear Tom Hood, who loved all animals-birds, beasts, and fishes -and delighted in conversing with me about those under my care :-

\section{THE STRAYING 'TOPUS.}

A LEGEND OF THE BRIGHTON AQUARIUM.

Have you heard of the Octopus-

'Topus of the feelers eight-

How he left his tank o'po'pus

Lump-fish to disintegrate?

To the lump-fish tank, as sprightly

As the Brighton coach, he'd ride;

For two passengers he nightly

Found convenient room inside. 
Although I had once seen the octopus in question crawl out of the water on to the rocks above the surface in the daytime, and had often witnessed his activity during the dark hours, and the surprising rapidity of his progress by crawling or walking, he had not been seen to do all of which he was accused. Every opportunity was, therefore, given to him of continuing his incursions into his neighbours' compartment, and it was hoped that he would be caught in the act. So acute, however, are these creatures in their perceptions, so quick of sight, and so sensitive to the light of even a distant lantern, that our suspected pirate would not start on a buccaneering expedition whilst anyone was cruising in the building. He seemed to know that he was watched ;

On his feelers, long and curly,

Homeward then he gently strode ;

And you'd have to get up early

To perceive him on the road.

But it happened Mr. Lawler,

Whom the lump-fish ought to thank,

Caught this very early caller,

"Dropt-in" on his neighbours' tank !

For some weeks the world lump-fishious

Very strangely vanished had ; -

So the visit was suspicious,

And appearances were bad !

Well for him, this brigand larky

Was not brought before J.P.

(Neither clergy, nor squire-archy)

But to Mr. Henry Lee.

Said he, "Punish on suspicion,

Is a thing I never will-

Catch him in the same position ;

Then I'll send him to the mill !"

Treadmill is a wear-and-tear case,

And Octopus would, you see,

Do four men upon a staircase-

Law, how tired the beast would be 
and for about a week remained quietly at home. During that time no more young lump-suckers were missing. Then he again broke bounds, and, moreover, prevailed on one of his class-mates to follow his bad example of going out on the loose.

One night these two individuals left their tank, and started in opposite directions on a voyage of discovery. One went east, the other went west; and, as if by preconcerted plan, neither was content merely to cross the frontier and visit his nearest neighbours, but both passed through, or over, one intervening tank, and settled down amongst the tribes beyond. One of them found himself in a Brobdingnag of crabs - a colony of giants too strong to be successfully invaded even by an armada of octopods. If he had arrived at Lilliput instead-a tank inhabited by pigmy crustaceans-he would soon have depopulated it, by clutching in his hateful embrace more victims per diem than ever an unwelcome; foul-mouthed dragon of old demanded as his daily dole of youths and maidens, to satisfy his inconvenient preference for their flesh as his daintiest dish. The other traveller found his way into Lobsterdom, and putting on a bold front, proceeded to attack the chicf. The lobster, though evidently alarmed, "showed fight," and the intruder was obliged to retreat, and seek refuge in a cranny of the rock-work. Although the lobster which bore the brunt of the attack was a very large one, I was at the time surprised that it so decisively vanquished the invader as to save from destruction the other smaller specimens of its kind, which were its companions. For it is an old notion, still generally believed by fishermen, that if an octopus approaches a "pot," or "stalker," in which are lobsters that have been entrapped, they will cast off their claws, and become literally sick from fright.

In his pleasant book, "Sub-tropical Rambles," Mr. Nicholas Pike, United States Consul at Mauritius, mentions that advantage is there taken by the native fishermen of the antipathy and instinctive fear with which the crustacea regard their enemy, the octopus (called by the Creoles, the "ourite," by the European 
residents, the "cat-fish,"), to lure the former from their holes. A long arm of the octopus is suspended at the entrance, and no sooner does the lobster or cray-fish catch sight of the dreaded weapon covered with suckers, than away he rushes in terror, and is soon caught by a noose of split bamboo firmly fixed over his tail.

In localities where the octopus abounds, the crustacea probably learn to regard it as an enemy to be dreaded, but this is certainly not the case with those which I have had opportunities of observing. The common shore crabs on which this animal is habitually fed in the Aquarium have no knowledge of their danger in its presence. When tossed into the tank they frequently run towards the monster who is waiting to devour them, and even scramble on to and over his back. It may be that, as in countries previousiy unvisited by man the birds and beasts, unacquainted with his destructive powers and carnivorous habits, show no fear of him at first sight, so the crabs and lobsters at Brighton so rarely see an octopus in their native haunts that they have not learned to recognise their deadly foe.

Another amusing illustration of the pedestrian powers of the octopus occurred some time afterwards at the Brighton Aquarium. In anticipation of the arrival of some literary and scientific friends, I had transferred an octopus from its tank to a large vase of water in my private room, that they might be able to examine it minutely. I left it for a quarter of an hour, and, on my return with them, found it toppling and sprawling along on the carpet. It had got out of the vase, tumbled off the table on to the floor, and reached the further. side of the room. Of course, it was immediately replaced in the water, and seemed none the worse for its singular promenade.

An incident described by Mr. Thomas Beale, surgeon of a South Sea whaling ship, in his "History of the Sperm Whale," has been quoted over and over again, not merely as proving that the octopus can quit the water, but as an illustration of its ferocity. It should rather be cited as an instance of unintentional 
exaggeration by a generally fair observer. Mr. Beale says :"While upon the Bonin Islands, searching for shells, which had just been left by the receding tide, I was much astonished at seeing at my feet a most extraordinary animal crawling towards the surf, which had only just left it. I had never seen one like it under such circumstances before; it therefore appeared the more remarkable. It was creeping on its eight legs, which, from their soft and flexible nature, bent considerably under the weight of its body, so that it was lifted by the efforts of its tentacula only a small distance from the rocks. It appeared much alarmed at seeing me, and made every effort to escape, while I was not much in the humour to endeavour to capture so ugly a customer, whose appearance excited a feeling of disgust, not unmixed with fear. I, however, endeavoured to prevent its career, by pressing on one of its legs with my foot, but although I made use of considerable force for that purpose, its strength was so great that it several times quickly liberated its member, in spite of all the efforts I could employ in this way on wet, slippery rocks. I now laid hold of one of the tentacles with my hand, and held it firmly, so that the limb appeared as if it would be torn asunder by our united strength. I soon gave it a powerful jerk, wishing to disengage it from the rocks to which it clung so forcibly by its suckers, which it effectually resisted; but the moment after, the apparently enraged animal lifted its head with its large eyes projecting from the middle of its body, and letting go its hold on the rocks, sprang upon my arm, which I had previously bared to the shoulder, and clung with its suckers to it with great power, endeavouring to get its beak, which I could now see between the roots of its arms, in a position to bite. A sensation of horror pervaded my whole frame when I found this monstrous animal had affixed itself so firmly upon my arm. Its cold, slimy grasp was extremely sickening, and I immediately called aloud to the captain who was also searching for shells at some distance, to come and release me from my disgusting assailant. He quickly 
arrived, and taking me down to the boat, during which I was employed in keeping the beak away from my hand, quickly released me by destroying my tormentor with the boat-knife, when I disengaged it by portions at a time. This animal must have measured across its expanded arms about four feet, while its body was not larger than a large clenched hand. It was that kind of sepia called by whalers 'rock-squid.' "

It was neither a "sepia" nor a "squid," but an octopus of very moderate size. The enraged animal lifting its head and springing on Mr. Beale's arm is very sensational, but very inaccurate; and it is simply impossible that he could have seen the beak whilst the animal was endeatouring to get it into position to bite him. The tragic killing of his "tormentor" with the boat-knife, and disengagement of its arms, bit by bit, was quite unnecessary. If he had grasped it firmly round the neck it would have instantly let go its hold. Aristotle was well aware of this, and it may be well for bathers to remember it.

I have frequently allowed an octopus to fix itself upon, and crawl over, my bare arm. It can always be detached in this manner. None have ever attempted to bite me. But although it is "nothing when you are used to it," it is not pleasant to have a stranger, of whose proclivities you know nothing, fasten himself upon you with such demonstration of attachment. To have the long, cold, damp arms of an octopus writhing and twining about one's wrist and hand, and fastening its hundreds of sucking cups all over them, gives a singularly uncomfortable sensationthe kind of feeling most persons would experience on grasping a handfil of lively snakes-so Mr. Beale may be excused for allowing his terror to excite his imagination and overcome his judgment.

The fishermen of the Mediterranean have a summary method of killing the octopus or cuttle. They turn back the arms over the head, and seizing the latter with their teeth compress it in the region of the brain. Death is instantaneous. 
M. Moquin Tandon, in his "World of the Sea," alluding to the peril to swimmers of contact with the octopus, gives a singular recipe for rendering the creature harmless. He says: "Dr. Franklin found that a few drops of vinegar on its back at once persuaded it to release its hold." So, too, would a red-hot poker, no doubt; and it would be almost as easy to apply the one as the other under water: for, supposing that swimmers were in the habit of carrying cruet bottles slung round their necks, considerable ingenuity would be required to enable one to pour a few drops of vinegar on the back of an octopus which was holding him by the ancle at some distance below the surface. To put vinegar on an octopus, as to put salt on a bird's tail, you must first catch it. I have somewhere read of a Dutch pedlar who sold a man a liquid for the extermination of fleas. "And how do you use it?" inquired his customer. "Ketch te flea, and drop von little drop into his mout," answered the pedlar. "Why!" exclaimed the purchaser, "I could kill it in half the time, by crushing it." "Vell," said the Dutchman, thoughtfully, "dat is a goot vay, too."

In August, I873, I received from Dr. R. Brisco Owen, of Haulfre, Beaumaris, a fellow of the Linnean Society since 1824 , the following communication respecting octopods quitting the water, and their capability of rapid progress on land :-

"I forward you a description of a curious species of octopod which I once met with in Torres Straits; but at the Brighton Aquarium, last month, I was examining the octopus there, and they struck me as being quite a different species to mine, their eyes especially different; the eyes of mine were full and open, as beautiful as the eye of the owl, which they resembled." It was in the month of September, I843, that I landed in Blackwood's Bay, on my passage through Torres Straits from Sydney to Madras. The ship on board of which I was a passenger was the Stratheden, Captain Howlett. On casting anchor in the bay, having cleared this most dangerous strait, which separates the 
northernmost point of Australia from New Guinea, a small party, including the captain, took boat and were rowed ashore, a distance of a good mile. Our passage in the boat was over a splendid field of coral, the water not being above a yard deep, and as clear as crystal. Landing on the shore of Blackwood's Bay, our party separated for the purpose of exploration; the captain pointing out to us the necessity of our being punctual as to time, not wandering too far, and observing the position of our boat for our return. The shore was an extensive flat, hard and clean to walk on, with much sea-weed growing on it. Having proceeded a considerable distance, and lost sight of my companions, great was my surprise to see an object start up suddenly, close to my feet, moving very rapidly, and evidently wishing to avoid me, and to get to the sea. After chasing it a short time, I was satisfied that the creature was an octopus, which I was desirous of capturing alive, and without injury. Its eyes, which were round, large, and wide open, descriptive of the greatest terror, struck me forcibly. Its speedy flight and wonderful powers of locomotion, I cannot account for: it appeared to me surprising that a creature with such a flexible structure as its tentacles, could outrun me. Our chase lasted so long that both pursuer and pursued were frequently obliged to halt from sheer exhaustion. At length, finding that I could not capture the animal, I flung my stick at it with force, and knocked it over, killing it with one blow, and, to my sorrow, ruining it as a specimen. On picking up the octopus, it was quite collapsed. The tentacles were about two feet long only. I am not surprised to have found this creature left by the receding tide; as it had plenty of seaweed, with little pools of water, to protect and shelter it, and abundance of the sea-slug (Holothuria cdulis), which no doubt it feeds on-fine specimens of which I met with, that would have suited the dainty palate of an alderman! I trust that credit may be given me for the veracity of this account. I have no object in deception. I have here stated what occurred to me; and being able to refer to my journal, my memory is freshened, 
though the circumstances made such an impression that I have often thought the matter over, and sought in books for confirmation of what I witnessed, but without success."

A similar instance was related in a letter to one of the morning papers (I think, the Daily Telegraph), about eight months previously; and the statement then appeared to me to be an attempt to hoax the public; for it seems impossible that an octopus can travel over the ground at the pace described. But it is not to be supposed that a gentleman of Dr. Owen's age and profession would volunteer information intentionally erroneous. Among the details given by him is one which is difficult to understand. The genus Octopus is especially characterised by the smallness of the eye. This is larger in Philoxenis and Argonauta; but in all of the family the iris is oblong, and not round. In the calamaries it is larger, and always circular; but the octopods alone of the cephalopoda, are able, by the disposition of their arms, to wali, or progress, on dry land, or to return to the water if cast upon the shore.

Marvellous as the above narrative may appear to the reader (and I confess I so regard it), it has been collaterally confirmed by an officer of high rank in the Royal Engineers, whose veracity is unquestionable, and who, without previous knowledge of Dr. Brisco Owen's communication, related to me, first verbally, and afterwards, at my request, in writing, a similar adventure which happened to himself.

"When at Bermuda," he said, "in r868, whilst sitting on a rock near the water, I saw a curious instance of the power of locomotion of these beasts. A small octopus emerged from the water, apparently in great terror: in two seconds he was followed by a larger one, evidently in chase. The little fellow might have been ten inches over all, the larger one about eighteen, or perhaps twenty, inches. Their mode of progression was most singular: in position something like the 'arabs' of the London streets, but not turning. Five arms seemed to be used in walking, or, rather, progressive motion; the remaining three 
being reserved for seizing. I should think the rate at which both animals went was as fast as a man could possibly walk, i.e, between five and six miles an hour. A larger octopus would undoubtedly cause a man following it to run, unless it chose to turn and face him."

Both of these accounts of the locomotive powers of the octopus are perfectly clear and definite; and, therefore, although we may say, with Horatio,_- "This is wondrous strange !" we must either entirely disbelieve two credible witnesses, or apply to the case the aphorism of Hamlet:- "There are more things in heaven and earth than are dreamt of in our philosophy." 


\section{CHAPTER VI.}

\section{NEW LIMBS FOR OLD ONES.}

IT is a not uncommon occurrence that when an octopus is caught, it is found to have one or more of its arms shorter than the rest, and showing marks of having been amputated, and of the formation of a new growth from the old cicatrix. Several such specimens have been brought to the Brighton Aquarium; one of which was particularly interesting. Two of its arms had evidently been bitten off about four inches from the base; and out from the end of each healed stump (which, in proportion to the length of the limb, was as if a man's arm had been amputated halfway between the shoulder and elbow) grew a slender little piece of newly-formed arm, about as large as a lady's stiletto, or a small button-hook-in fact, just the equivalent of worthy Captain Cuttle's iron hook, which did duty for his lost hand. It was not a specimen of the remarkable hectocotylus development of the arm of the male octopus which takes place during the breeding season, but an illustrative example of the repair and restoration of a mutilated limb.*

* Professor Steenstrup says that almost every octopus he has examined has had one or two arms reproduced, and that he has seen females in which all the eight arms had been lost, but were more or less restored; also a male in which the same was the case on seven of the arms,- - the hectocotylized limb alone being uninjured. He adds that whilst the Octopoda possess the power of reproducing with great facility and rapidity their arms which are exposed to so many enemies, the Decapoda-(the Sepiidæ and Squids) - appear to be incapable of thus repairing and replacing accidental injuries.- [See the translation of his paper by Mr. W. S. Dallas, in the "Ann. and Mag. of Nat. Histy." of August, I 857 ; No. I16, 2nd series ; p. 107.] 
This reparative power is possessed by some other animals, of which the starfishes and crustacea are the most familiar instances. The lobster and the crab, if they find themselves in depressing circumstances, are addicted to malingering. They do not go so far as to commit suicide; but, stopping short of that, perpetrate a kind of demi-semi-self-immolation. In a sudden passion of fear or anger, they will sometimes fling off one or both of their large claws, and that which they thus do impulsively and in haste, they repent and repair at leisure-like the intemperate man we sometimes read of in the police news, who goes home and smashes the crockery, and, when he is able to reflect on his folly, is glad to make good the damage as quickly and as quietly as he can.

The starfishes, too, as the common "five-finger" (Uraster), and the brittle-star (Ophiocoma), - which by-the-by, is not half as brittle as has been supposed-can throw off their limbs in a pet, and grow them again. But in both of these the act is voluntary, and the dismemberment complete. If the claw of a lobster or crab be severed, or wounded in any part of its length, the animal will bleed, and waste, and die of the consequent exhaustion. I have noticed that, especially in the spiny lobster or sea cray-fish (Palimurus), the blood flows freely many hours after death, and that when I have had occasion to remove the abdominal and caudal leaf-like appendages of a dead crayfish for dissection and microscopical examination, the blood and serum have poured from the part where the cut has been made, and thickened on the stone slab in a firm, gelatinous sheet, of the colour and consistency of guava jelly.

The only joint from which new growth can start in the crustacea is that connected with the body. The whole limb must be got rid of. The octopus, on the contrary, is incapable of voluntary dismemberment, but has the faculty of reproducing, as an outgrowth from the old stump, any portion of an arm (or leg) which may have been lost by misadventure. I say "arm or leg," for one hardly knows which these eight appendages should be called. If 
they are legs, the octopus can hold on with them as tightly as the "old man of the sea" gripped Sinbad the Sailor, and use them as dexterously as the "armless girl," who cuts out with hers the pretty paper designs which she sells to visitors. If they are arms, he can walk on them, head downwards, under water, more cleverly than the most agile monkey or street arab. So we may call them either or both.

Returning to our mutilated octopus; - we transfer him from the tank in which he had been temporarily placed to the wet pavement, that we may better observe his movements when crawling. He scrambles and shuffles away, and makes the best use he can of the jury-rigging he has fitted on to his old stumps. As he does so, his keen eyes, mounted on little hillocks, peer furtively around him; and while he sidles off from his too admiring persecutors, he casts a doubtful, half-frightened, half-defiant glance behind him, like a schoolboy, timid in the dark, who fancies a ghost is following him. His cousin the cuttle-fish (Sepia) has an eye, round like that of an owl, which stares you out of countenance, and puzzles you by its immobility ; the pupil of the eye of an octopus is like that of a tiger turned half round. The perpendicularlyelongated pupil of the cat gleams with hot ferocity: the calm, cunning gaze of the octopus from out the narrow horizontal slit of its compressed eyelids freezes by its cold cruelty.

Now, let us try to conjecture the "fons et origo mali"-the source of the injury of the two lopped arms.

There lingers still amongst the fishermen of the Mediterranean a very ancient belief that the octopus when pushed by hunger will gnaw and devour portions of its arms. Aristotle knew of it, and positively contradicted it; but a fallacy once planted is hard to eradicate. You may cut it down, and apparently destroy it, root and branch, but its seeds are scattered abroad, and spring up elsewhere and in unexpected places. Accordingly we find Oppian, more than five centuries later, disseminating the same old notion, and comparing this habit of the animal with that of the bear 
obtaining nutriment from his paws by sucking them during his hybernation.

When wintry skies o'er the black ocean frown, And clouds hang low with ripen'd storms o'er-grown, Close in the shelter of some vaulted cave

The soft-skinn'd prekes their porous bodies save.

But forc'd by want, while rougher seas they dread,

On their own feet, necessitous, are fed.

But when returning spring serenes the skies, Nature the growing parts anew supplies.

Again on breezy sands the roamers creep, Twine to the rocks, or paddle in the deep.

Doubtless the God whose will commands the seas,

Whom liquid worlds and wat'ry natives please, Has taught the fish by tedious wants opprest Life to preserve and be himself the feast.

The fact is, that the larger predatory fishes regard an octopus as very acceptable food, and there is no better bait for many of them than a portion of one of its arms. Some of the cetacea also are very fond of them, and whalers have often reported that when a "fish" (as they call it) is struck it disgorges the contents of its stomach, amongst which they have noticed parts of the arms of cuttle-fishes which, judging from the size of their limbs, must have been very large specimens. The food of the sperm whale consists largely of the gregarious squids, and the presence in spermaceti of their undigested beaks is accepted as a test of its being genuine. That old fish-reptile, the Ichthyosaurus, also, preyed upon them; and portions of the horny rings of their suckers were discovered in its coprolites by Dean Buckland. Amongst the worst enemies of the octopus in British home waters is the conger. They are both rock-dwellers, and if the voracious fish coine upon his cephalopod neighbour unseen, he makes a meal of him, or, failing to drag him from his hold, bites off as much of one or two of his arms as he can conveniently obtain. The conger, therefore, is generally the author of the injury which the octopus has been unfairly accused of inflicting on itself. 
The Curator of the Havre Aquarium describes an attack by congers on an octopus which he had thrown into their tank. As soon as the latter touched the bottom it examined every corner of the stone-work. The moment it perceived a conger it seemed to feel instinctively the danger which menaced it, and endeavoured to conceal its presence by stretching itself along a rock, the colour of which it immediately assumed. Finding this useless, and seeing that it was discovered, it changed its tactics, and shot backward, in quick retreat, leaving behind it a long black trail of turbid water, formed by the discharge of its ink. Then it fixed itself to a rock, with all its arms surrounding and protecting its body, and presenting on all exposed sides a surface furnished with suckers. In this position it awaited the attack of its enemies. A conger approached, searched with its snout for a vulnerable place, and, having found one, seized with its teeth a mouthful of the living flesh. Then, straightening itself out in the water, it turned round and round with giddy rapidity, until the arm was, with a violent wrench, torn away from the body of the victim. Each bite of a conger cost the unfortunate creature a limb, and, at length, nothing remained but its dismembered body, which was finally devoured; - - some dog-fishes, attracted by the fray, partaking of the feast.

I have always refused to permit so shocking a scene to be repeated at the Brighton Aquarium. The Havre experiment has taught us all that is to be learned from it concerning the mode of attack of the conger, and the octopod's strategy of defence. That the flesh of the latter is a favourite food of congers, I have repeatedly proved by watching the eagerness with which they will rend limb from limb, and devour the body of a dead octopus to which I sometimes treat them after removing such portions as may be required for dissection and preservation.

An octopus is sometimes, though rarely, severely injured in battle by one of its own species. On one occasion when a newlyarrived specimen was put in a tank with others which had dwelt 
there for some time, these old habitués made a fierce onslaught on it, and the new-comer had one of its arms torn away. It would certainly have been killed if one of the attendants had not rescued and removed it. Aristotle says that the octopus does not eat its congeners, and D'Orbigny endorses his opinion. Nevertheless one instance of this cannibalism has occurred in the Brighton Aquarium; and in that on the Boulevard Montmartre, Paris, in 1867 , two octopuses fought and the victor devoured the vanquished.

Another reparation or renewal by the octopods of worn or injured portions of their limbs is the frequent shedding of the outer skins of their suckers, the epidermis of the flat surface of them, by which they adhere, and travel from place to place. These cast-off skins may generally be seen floating in the water in their tanks in the form of very thin, filmy discs, with a hole in the centre. Seeking a reason for this, it appears to me that these, their feet-coverings, become worn by crawling and climbing over the rough rocks, and that it is a provision of nature for the renewal of the holding surface of their suckers, necessary for the production of a sufficient vacuum, and the very best method by which the repairs of the soles of their boots can be "neatly executed." And, as their feet increase in size with their general growth, it may also be that they outgrow their shoes as quickly as children do theirs, and that, therefore, they cast them periodically when they require larger ones, as the barnacles do their plumes, the crustacea their shells, and snakes their skins.

Sometimes the whole shoe is thrown off; at others only the sole. When the octopus desires to get rid of this worn skin it curls its arms together close to its body in a peculiar manner, and rubs them one against another with a rapid motion of coiling and uncoiling which suggests the action of "Sir Jacob," the father of Thomas Hood's "Miss Kilmansegg," when he

"In the fulness of joy and hope,

Seemed washing his hands with invisible soap

In imperceptible water." 


\section{NEW LIMBS FOR OLD ONES.}

It appears to delight in thus cleaning itself and giving itself a good rubbing and scrubbing all over, as a strong man enjoys his "matutinal tub" and a hearty rub with a rough towel afterwards; or as a bird, with evident pleasure, preens its feathers, and bathes in water or sand. This cleansing process has been erroneously supposed to indicate sexual excitement. 


\section{CHAPTER VII.}

\section{SPAWNING OF THE OCTOPUS.}

THE first instance of the octopus spawning in an aquarium in this country occurred at Brighton on the 19 th of June, I873. A large female octopus, caught at Dieppe, was brought in on the 26th of the preceding April, and, immediately on her arrival, a fine male previously received from Mevagissey conceived a liking for her, and evidently rejoicing in the good fortune which had provided for him a suitable mate, paid her such assiduous court, that his addresses were quickly accepted. It was a case of "love at first sight," and in three days the captive damsel was wooed and won. The event above mentioned was, therefore, not unexpected. Our octopus, fortunately selected as a suitable site for her nest, a recess in the rock-work, close to the front glass of the tank, so that her movements could be easily observed. Her body just filled the entrance to it, and she further strengthened its defences by dragging to the mouth of her cavern two dozen or more of living oysters, and piling them one on another to form a breastwork or barricade, behind which she ensconced herself. Over this rampart she peered with her great, sleepless, prominent eyes ; her two foremost arms extended beyond it, their extremities coiling and writhing in ceaseless motion, as if prepared to strike out right and left at any intruder. She seemed never to be taken unawares, and was no more to be caught napping than a cunning middy "caulking it" in the middle watch. Couchant, and on the "look-out," like Sir Edwin Landseer's lions, she barred with her body the passage to her den, ready to defend it against all foes. Her companions evidently felt that it was dangerous to 
approach an excited mother guarding her offspring, and none ventured to go within arm's length of her. Even her forlorn husband was made to keep his distance. If he dared to approach with intent to whisper soft words of affection into his partner's ear, or to look with paternal pride on the newly-born infants, the lady roused herself with menacing air, and slowly rose till her head over-topped the barrier; by an instantaneous expansion of the pigment vesicles of the skin, a dark flush of anger tinged the whole surface of the body; the two upper arms were uncoiled and stretched out to their utmost length towards the interloper; and the poor snubbed, hen-pecked father, finding his nose put out of joint by the precious baby, which belonged as much to himself as to its fussy mother, invariably shrank from their formidable contact, and sorrowfully and sullenly retreated, to muse, perhaps, on the brief duration of cephalopodal marital happiness. All his fellows in the tank knew that he was in bad humour, and took care to keep out of his way. As soon as they saw him coming towards them they gathered their arms close together in a straight line, and swam off rapidly, tail first, to the further side of the tank.

The eggs of the octopus, when first laid, are small, oval, translucent granules, resembling little grains of rice, not quite an eighth of an inch long. They grow along and around a common stalk, to which every egg is separately attached, as grapes form part of a bunch. Each of the elongated bunches is affixed by a glutinous secretion to the surface of a rock or stone (never to seaweed, as has been erroneously stated), and hangs pendent by its stalk in a long white cluster, like a magnified catkin of the filbert, or, to use Aristotle's simile, like the fruit of the white alder. The length and number of these bunches varies according to the age and condition of the parent. Those produced by a young octopus are seldom more than about three inches long, and from twelve to twenty in number; but a full-grown female will deposit from forty to fifty of such clusters, each about 
five inches in length. I have counted the eggs of which these clusters are composed, and find that there are about a thousand in each: so that a large octopus produces in one laying, usually extended over three days, a

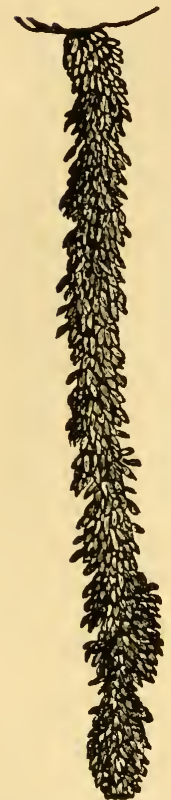

Fig. 6. Eggs of the Octopus. (O. viulgaris) progeny of from 40,000 to 50,000 . Our brooding French octopus, when undisturbed, would pass one of her arms beneath the hanging bunches of her eggs, and dilating the membrane on each side of it into a boat-shaped hollow, would gather and receive them in it as in a trough or cradle, exhibiting in its general shape and outline a remarkable similarity to those of the argonaut, or "paper-nautilus," with the eggs of which octopod its own are, as I have already explained, almost identical in form and appearance. Then she would caress and gently rub them, occasionally turning towards them the mouth of her flexible exhalent and locomotor tube, like the nozzle of a fireman's hose-pipe, so as to direct upon them a jet of the excurrent water. I believe that the object of the syringing process is to free the eggs from parasitic animalcules, and possibly to prevent the growth of conferva, which I have found rapidly overspread those removed from her attention. Week after week, she continued to attend to them with the most watchful and assiduous care, seldom leaving them for an instant except to take food, which, without a brief abandonment of her position, would be beyond her reach. Aristotle asserted that while the female is incubating she takes no food. This is incorrect.

In the tank with our specimen were seven others of her species, and to supply them with food about five-and-twenty living shore crabs (Carcinus manas) were daily tossed into it. Although she 
so seldom left her nest, she generally obtained her share of these, and would seize with her suckers, and draw towards her, sometimes, three at a time, one by each of three of her arms. Their shells were soon broken and torn apart by her powerful beak, and when she had devoured the contents the hard débris was cast out of her den.

But although the old naturalist of Stageira was mistaken in supposing that the female octopus does not take food during the period of the development of her ova, he was right in believing that her anxiety for her progeny, and her unremitting care of them, tell injuriously upon her health. A brooding octopus shows signs of diminished bodily vigour, as a sitting hen bird loses flesh whilst hatching her eggs. Her respiration at times becomes laboured. When the water is inhaled ( $I$ use the word intentionally, for the animal brcathes the oxygen contained in it) at the open part of the mantle-sac, the siphon-tube, at its orifice, is often drawn forcibly inward; and when the pair of bellows of the body close, the same opening of the tube is distended to its fullest capacity by the outrush of the exhaled water. Repeated observations have shown that it not unfrequently happens that the vital powers of the octopus are so exhausted by her protracted maternal cares that she dies when relieved by the hatching of her eggs from the necessity of further vigils. Many also die in the act of spawning, or when distended with ova.

To return to our mother octopus at Brighton,- at the end of the fifth week from the deposit of her ova she began to exhibit considerable irritation and restlessness, in consequence of the annoyance she experienced from visitors trying to rouse her to movement, or to frighten her from her eggs, by knocking at the glass with coins or sticks, and flouting pocket-handkerchiefs in front of her. I found that on some of these occasions, in her excitement, whilst protecting her eggs from the supposed danger, she had torn away the lower portion of some of the clusters, and that their number was considerably diminished. It therefore 
became necessary to screen her from the public gaze. Fearing also that, notwithstanding the cessation of the interruption to which she had been subjected, she might by her over-fussiness destroy the remainder; or that even if her progeny were safely born, they might hatch out unperceived, and thus our hopes be frustrated and an important observation lost, I decided on removing some of them from the exhibition tank, and placing them in a smaller one in the laboratory, where they could be closely watched. The water was therefore run off till a depth of only about six inches remained; and one of the catkin-like bunches of eggs was carefully detached. To do this neatly, without disturbing the other clusters, was not so easy as it might be supposed; for not only did the hen octopus guard the entrance to her recess, and require careful handling, but the old male also was pugnacious. As soon as he espied his keeper in the tank, he strode forth from his corner towards him, looking exceedingly savage, and making a demonstration of attack which would have frightened a novice, and led a looker-on to believe that the intruder was about to be the centre figure in a Laocoon group of writhing, twining octopods, and to suffer the fate of Clubin, or to escape only after a terrible combat, like Gilliatt, in M. Victor Hugo's novel. But the old fellow's bark was worse than his bite, for on a bare arm being presented to him in the shallow water, he made no attempt to hold or bite it, but merely scrambled and crawled harmlessly over it.

By the removal of a portion of these eggs I hoped, also, that an interesting question concerning their development might be finally answered. Aristotle had been understood to affirm that the parent octopus "incubates" her eggs. I had always expressed very decidedly my opinion, derived from previous experiments on the eggs of the cuttle-fish and squid (Sepia and Loligo) that, the ova once impregnated, no incubation by the parent is required or takes place in a sense equivalent to that of a fowl developing a chick by the warmth of its body; but that her unremit- 
ting attention to them is solely for the purpose of protecting them from injury, keeping them free from animal and vegetable parasites, and preventing their being devoured by fishes, or members of her own tribe-possibly by their own father. If I had felt myself free to act according to my inclination, I should, at once, have removed a larger number of the eggs; but in matters concerning which nothing is positively known, and everything has to be learned, caution is requisite. There was good reason for hesitation, when care in the conduct of the observation might remove the doubts of centuries. The first thing to be ascertained was-Had the ova been properly fecundated-did they contain, each, a living embryo? The microscope answered "Yes." Under a low power a young octopus was seen moving freely in the fluid contained in each transparent granule, the bright orange-brown colour in the pigment cells of its skin flashing, dying out, and re-appearing in another place, like sparks in tinder. And I was astonished to see that the little creature within the unbroken membrane was already endowed with the power of assimilating its colour to that of its surroundings. When light was reflected upon its surface, and through its translucent body, from a piece of white paper laid on the mirror of the instrument, it became pallid and colourless : on a bronze penny being substituted for the paper, it assumed a darker hue; and (which was still more remarkable) on its being disturbed by a slight compression or agitation of the egg, its surface became suffused with the red flush of anger and irritation which characterises the adult under provocation.

It having been seen that many of the eggs left in their original position had been bruised by the mother octopus, and that there were black marks on the stone beneath them, betokening the presence of decomposition, I was anxious to remove the remainder from her; but, for the reason above mentioned, amongst others, I considered it would be prudent to assure myself that the eggs transferred to the smaller tank retained their 
vitality. Seeing, at the expiration of four days, that the young animals within them were as lively as ever, and progressing so rapidly that their escape from the egg might soon be expected, I had the larger tank partly emptied again, for the purpose of taking from the nest any that might still be uninjured. It was found, however, that those which had not been torn away by the parent had been squeezed by her between herself and the rockwork, and were consequently dead, only a very few showing signs of having been prematurely hatched by the violent rupture of the envelope. She had overlain her babies. Those which were taken from her on the forty-second day from their extrusion for special inspection, were successfully hatched, and I do not doubt that if they could have been kept clean and free from parasites this would have taken place if they had been detached immediately after they were laid. The young octopods made their appearance on the 8th, 9th, and Ioth of August: the eggs had been extruded on the I th, $^{\text {th }}$ oth, and 2 Ist of June, and thus, although it was proved, as I expected, that the development of the embryo does not depend on incubation, the accuracy of Aristotle's statement that its period in the egg is fifty days was completely and satisfactorily confirmed.

In the first week of January, 1875 , another brood of young octopods was hatched in the Brighton Aquarium, and in this, as in the former instance, the period of development was that assigned to it by Aristotle. From observations made during the previous winter I did not expect that maturity would be completed within this term. Two "nestings" of octopus then occurred; and after twenty days, from time to time, as opportunity offered, when the mother left them for a minute in pursuit of an active crab scuffling away to the further end of the tank, one of the clusters of eggs was removed, and suspended in a separate cistern. The half-formed embryo was visible, though motionless, within the membranous envelope; therefore it was evident that the fertilisation of the ova had been effected. But although the parent, in 
both cases, assiduously guarded them for nearly three monthsalmost twice the, apparently, normal period-they were addled, as were also those which had been detached from under her care. It appeared to me probable that the vitality of the embryo was destroyed in an early stage by the lower temperature of the water during the winter months, but I was not without hopes that their progress towards maturity might prove to be merely retarded by the same influence, - an effect which is well known to be produced by cold on the ova of the salmonidæ. In order to test this, some of the eggs were placed in a tank in the warm boiler-house, but without any beneficial results. Yet the brood referred to was hatched in water of the same temperature as that in which the former ones were addled, varying little from $54 \mathrm{deg}$. Fahrenheit. I am unable to account for this; so I reserve my opinion of the cause of failure, and am content to watch, and wait, and patiently note facts, and to abstain from propounding theories on unsafe bases.

Everyone who loves and studies animals knows that each differs from others of its species, in its habits and little ways, as distinctly as children, and men, and women are diverse in character and disposition. The horses you have owned, the dogs you have loved, your cats, parrots, and even your pet cage-birds and little white mice, have possessed widely varying characters and idiosyncrasies. Fishes, the crustacea, and even the octopods are not excepted from this individuality. The hen octopus in question, whilst on sentry duty guarding her undeveloped progeny, assumed a position and attitude totally different from that adopted by her predecessor in maternal joys. The syringing of her eggs with a current of water from the syphon tube, was repeated by her; but she never cradled them, as did the other, in the expanded membrane of a limb. Her usual posture was with the under portion of her body presented to them, her eight arms turned completely back, exposing their under surface armed with their battery of suckers, the muzzles of the latter pointing in every direction, and the tip of the hard, horny beak, just dis- 
cernible. The fine ends of the arms might sometimes be seen gently winding amongst the clusters of eggs as tenderly and lovingly as a father's fingers through the tresses of a darling child, but there was no evident nursing in this case.

An octopus about to spawn, like some birds in search of a nesting-place, seeks the most retired nook she can find in which to deposit her eggs. The elasticity of her body enables her to squeeze herself through a very small orifice; and, therefore, the narrower the entry to her den the more suitable is it for her purpose, because the better adapted for defence against enemies and intruders. A curious instance of the choice of such a nestingplace came under my notice in March, 1874. Some fishermen, whilst dredging in the Channel off Brighton, brought up an earthen jar or carboy, which would hold about two gallons. It was covered with serpulæ, \&c., and was forthwith taken to the Aquarium. There it was discovered that it contained an octopus and her eggs. The neck of the jar was only two inches in diameter : the octopus was a fully-grown specimen.

The young octopus fresh from the egg is of about the size of a large flea, and when irritated is of nearly the same colour. It is very different in appearance from an adult individual of the same species. At first sight it is more like a sepia, without its tentacles, than an octopus. The arms, which will afterwards be four or five times the length of its body, are so rudimentary as to be even shorter in proportion than the pedal arms of the cuttle-fish, and appear only as little conical excrescences, having points of hairlike fineness, and arranged in the form of an eight-rayed coronet around the head.

At this early stage of its existence the young octopus seeks and enjoys the light which it will, later in life, carefully shun. It manifests no desire to hide itself in crevices and recesses, as the adult does, but swims freely about in the water, often close to the surface, propelling itself backward by a series of little jerks caused by each stroke of the force pump, which expels a jet of 
water from the out-flow pipe of the syphon. This contrast of its habits in youth and age is so remarkable that when, after witnessing the gay activity of the movements of the child-octopus, I again watched the furtive, skulking habits of its shrivelled-skinned father, I could not help comparing the latter with the old thief-trainer in "Oliver Twist," and wondering whether there ever could have been a time in the life of Fagin the Jew when he was innocent and frolicsome, and played, and leaped, and ran, and danced, and revelled in the sin-exposing sunshine, ere the light of day became odious to him, and he shrank from it as a danger to be dreaded, and kept himself hidden in his den whilst his emissaries went out, like the arms of the old octopus, in search of prey for the benefit of their employer.

I can say but little concerning the fertilisation of the eggs of the octopidæ in a book intended for readers of all classes, but it is so remarkable that this chapter would be incomplete without a few words upon the subject. They are fecundated before, not after, their extrusion. In the breeding season a curious alteration takes place in one of the arms of the male octopus; according to Steenstrup, always the third on the right side, although it has been stated that the third arm on the left is sometimes the one thus affected. The limb becomes swollen, and from it is developed a long, worm-like process, furnished with two longitudinal rows of suckers, from the extremity of which extends a slender, elongated filament. When its owner offers his hand in marriage to a lady octopus she accepts it, and kceps it, and walks away with it, for this singular outgrowth is then detached from the arm of her suitor, and becomes a moving creature, having separate life, * and continuing to exist for some time after being transferred to her keeping. In the meanwhile the lost portion of the "hectocotylized" arm of the male is gradually reproduced, and in due time it assumes its former appearance.

* Several specimens of the hectocotylus in this condition may be seen in the Museum of Natural History, Paris. 
The habits of the Eledone, of which there is only one British species, $E$. cirrosa, are the same as those of Octopus vulgaris, from which it chiefly differs in having only one row of suckers instead of two along the under surface of its arms. Individuals of this species have occasionally deposited a few eggs in the Brighton Aquarium; but these have not, hitherto, arrived at maturity. They are considerably larger than those of the octopus, and not so numerous. The eledone is not so hardy as its relative, and, in captivity, the female generally dies in spawning.

It is impossible for any student or observer of these animals to avoid recognition of Aristotle's wonderfully intimate knowledge of their life-history, embryology, sexual conditions, and anatomy. When I first saw the octopus guarding her eggs the thought immediately rose in my mind,- "Aristotle must have had an aquarium!" He might have learned by observations at the seaside, on the coast of the Mediterranean, the mode of progress of the octopus when swimming and crawling, its change of colour when excited, the form of its eggs, \&c., which he has correctly described; but it is impossible that he could have so exactly designated the duration of the existence of the embryo in the egg without having had opportunities of noticing the date of its extrusion, and that of the escape of the young octopods by the rupture of the envelope. His mention of the remarkable sexual development of one of the arms, its use in the impregnation of the ova, their apparent incubation by the mother, and her incessant attention to her charge, also indicates that, during the intervening time, the male and the brooding female were continually under his inspection. We are therefore led to the conclusion that the marine aquarium, in some form, is one of the things that are not "new under the sun." 


\section{CHAPTER VIII. \\ CUTTLES AND SQUIDS.}

THE common cuttle-fish (Sepia officinalis), (often called by sailors the "scuttle"), though flabby and clammy in death, is a lovely object when alive. Unlike, the skulking, hiding octopus, but equally rapacious, it loves the day-light and the freedom of

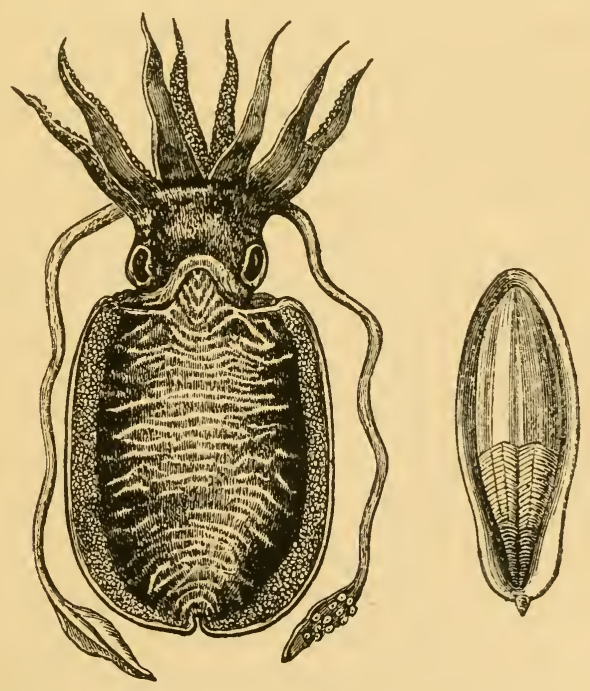

Fig. 7. The common Cuttle-fish (Sepia officinalis), and its internal shell or "sepiostaire.

the open sea. Its predatory acts are not those of a conceale; in and ambushed brigand lying in wait behind a rock, or peeping furtively from within the gloomy shadow of a cave; but it may better be compared to the war-like Comanche vidette, seated motion- 
less on his horse, and scanning from some elevated knoll a wide expanse of prairie, in readiness to swoop upon a weak or unarmed foe. Poised near the surface of the water, like a hawk in the air, the sepia moves gently to and fro in its tank by graceful undulations of its lateral fins, - an exquisite play of colour occasionally taking place over its beautifully barred and mottled back. When thus tranquil, its eight pedal arms are usually brought close together, and droop in front of its head, like the trunk of an elephant, shortened; its two longer tentacular arms being coiled up within the others, and unseen. Only when some small fish is given to it, as food, is its facility of rapid motion displayed. Then, quickly as a kingfisher darts upon a minnow, it pounces on its prey, enfolds it in its fatal " cuddle" * or embrace, and retires to a recess of its abode to tear it piece-meal with its horny beak, and rend it into minutest shreds with its jagged tongue. In shallow water, however, it will often rest for hours on the bottom, after a hearty meal, looking very much like a sleepy tortoise. The cuttlefishes are so voracious that fishermen regard them as unwelcome visitors. Some localities on our own coasts are occasionally so infested by them that the drift-netting has to be abandoned, in consequence of their devouring the fish, or rendering them unsaleable by tearing them with their beaks as they hang in the meshes.

The Sepia seldom lives long in confinement. Although, like the calamaries, it often swims gently forward by the use of its side fins, its usual mode of rapid progress is the same as that of the octopus; namely, darting backwards by the ejection of a stream of water through the funnel. In a limited space, like an aquarium tank, there is not sufficient room for its rocket-like rush, and therefore its hinder extremities so frequently come in contact with the rock-work, that the skin is worn through until the edge of the

* Mr. Gwyn Jeffreys says :- "The derivation of the word 'cuttle' is given in the 'Imperial Dictionary' as from the Saxon verb 'cudele;' in Welsh, 'curiarv;' and in the Armorican, 'cuttaff,' or 'cuddyo,' all signifying the sense of withdrawing or hiding; hence our pet word 'cuddle." 
internal shell, or "sepiostaire" is visible, and death follows. The animal cannot see behind it; and so it often happens that it similarly comes to grief in its natural habitat, especially in calm weather, when, as Edward Forbes says, " not a ripple breaks upon the pebbles to warn it that the shore is near. An enemy appears : the creature ejects its ink,* like a sharp-shooter discharging his rifle ere he retreats, and then, darting away, tail foremost, under cover of the cloud, grounds itself high upon the beach, and perishes there."

The following are the dimensions of a fine male Sepia which I. dissected at the Brighton Aquarium, July 3, 1875 :-

Diameter of body across the back and lateral fins $9 \frac{1}{2}$ in.

Length of body, including marginal fin . . . I2 "

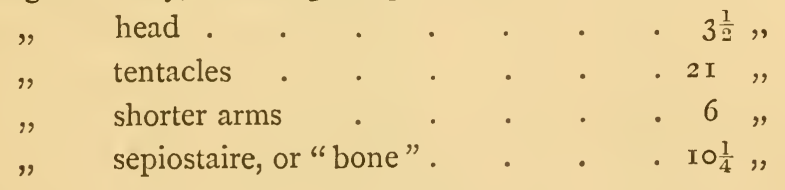

Specimens of another of the Sepiidæ, the diminutive Sepiola (S. Rondeletii)-a veritable Liliputian among cuttles-are sometimes caught in shrimp-nets, and brought to the Aquarium. The mantle-sac enclosing the body of this little Tom Thumb cephalopod is about an inch in length, and in shape like a short widebore mortar. The head may be supposed to be the tompion fixed in the muzzle; and where the trunnions would be are two little flat fins of rounded outline. The large goggle eyes seem to be out of all proportion to the size of their owner; but they are, apparently, "all the better to see with," either to watch for a tender young shrimp coming within arm's reach, or to perceive an approaching enemy. Sepiola, like its comparatively Brobdingnagian relatives, has the faculty of rapidly changing colour, and, if angered or alarmed, its hue is almost instantaneously altered

* See page 94. 
from a pale parchment dotted with pink, to a deep reddish brown. In its habits this little animal differs as much from the sepia as the latter from the octopus. It naturally buries itself up to its

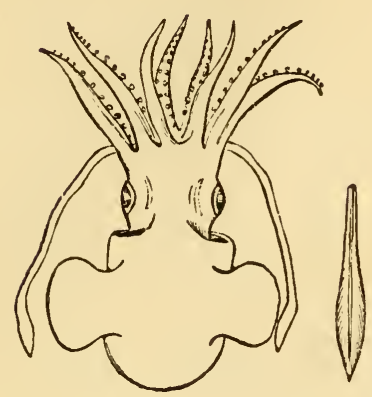

Fig. 8. Sepiola Rondeletii. eyes in the sand; but as sand is apt to harbour impurities, which in a bowl or tank become corrupt, and generate poisonous sulphuretted hydrogen, the bottom of these receptacles is usually covered with fine shingle. It is most interesting to notice how, in obeying its burrowing propensity, the Sepiola adapts itself to its circumstances, and entirely deviates from its customary mode of procedure. To make a sand pit for its hiding-place, it will direct upon it strong jets of water from its funnel, and thus blow out a cavity in which to seat itself, and allow the disturbed particles to settle over and around it; but, as the pebbles are too heavy to be thus displaced by its blasting apparatus, it removes them, one at a time, by mears of its arms, which are large and strong in proportion to its little short body.

Now and again specimens of the "little squid" (Loligo media) are brought in. Their movements are very graceful and pleasing. They are gregarious, like other squids, and keep close together. By the action of their tail-fins, they can either "go a-head" or "turn astern;" and it is very interesting to watch their manœuvres. We once had in one of the tanks four of these "little squids" (which are only about four inches long), and I was much amused by seeing them perform, in a most ludicrous manner, the quadrille figure called La Trenise. Three of them ranged themselves side by side, and advanced towards, and retired from a solitary one, who, for some reason, was not received 
into their rank, but faced them. When they withdrew, stern first, to the back of the tank, the lonely one followed them up with a pas seul. But there the similitude ended. He was repeatedly driven backwards to his former position, and was not allowed the privilege of taking his partner with him.

These "little squids" are impudently voracious. I have seen
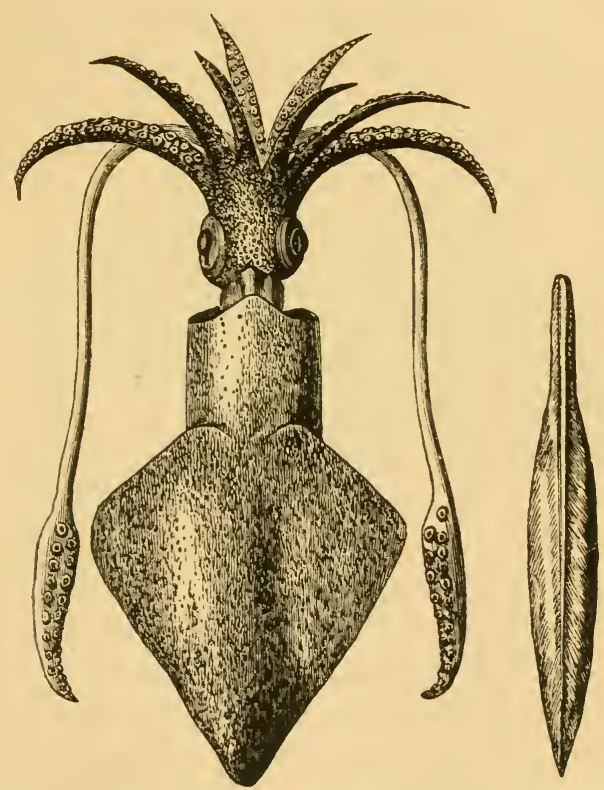

Fig. 9. The common Squid (Loligo vulgaris) and its internal horny shell, or "pen."

one in single combat with a young dog-fish about four inches long. At first I thought the fish was the aggressor, and had seized one of the tentacular arms of the little Loligo as a good substitute for a worm; but it was soon apparent that the affray had been provoked by the carnivorous cephalopod, and that the puppy-fish would get the worst of it;-so they were separated.

The common squid (Loligo anlgaris) is sometimes met with by 
the trawlers off Brighton, and brought to the Aquarium in considerable numbers. On the Sussex coast this species does not appear to assemble in very large brigades, but rather in small companies. No adult individuals have been received. They are all "youths in their teens," not full-grown squids; to which they bear the same proportion in size as a drum-and-fife-band of boys to a regiment of stalwart soldiers. The largest English calamary I have seen, though larger specimens have been cast ashore on the west coast of Ireland, is one which my friend Dr. Bowerbank kindly sent to me, of a species comparatively rarely found in British home-waters,-Ommastrephes sagittatus. Its dimensions were as follows :-

Length from front of head to point of tail, $21 \frac{1}{2}$ inches.

Circumference of body, 14 inches.

Greatest breadth across tail-fins, 14 inches.

Length of each tentacular arm, 28 inches.

Length of spread from tip to tip of the two tentacular arms, 4 feet ro inches.

It was taken in the mackerel nets, and brought into Hastings by one of the fishing boats on the 26 th of September, 1873 . Unfortunately it had been much bruised and knocked about by its captors. On endeavouring to extract the internal horny shell, gladius, or "pen," which Mr. Gwyn Jeffreys well describes as resembling a very long oar with a broad handle, I found that it had been sadly smashed and broken across into many pieces. Fishermen often handle very roughly animals taken in their nets which have no value as marketable food, and this splendid squid had probably been dashed down on the deck of the boat with great violence. A pretence of some pains having been taken to keep it alive was, I am told, afterwards made. Although the "sagittated calamary" is uncommon on our own shores, it visits annually the coasts of Newfoundland in vast shoals, and is the 
species to which I have referred in another chapter, as being one of the staple baits used in the cod-fishery of that country.*

The eggs of the various families of cephalopods differ greatly from each other. Those of the Cuttle (Sepia) are like black grapes, each having a flexible stalk looking and feeling like indiarubber. The mother takes a turn with this stalk round the stem of the twig or seaweed to which she wishes to attach the egg; the india-rubber-like material is soft and sticky when first laid; and so, instead of splicing the loop, she brings the end round to the

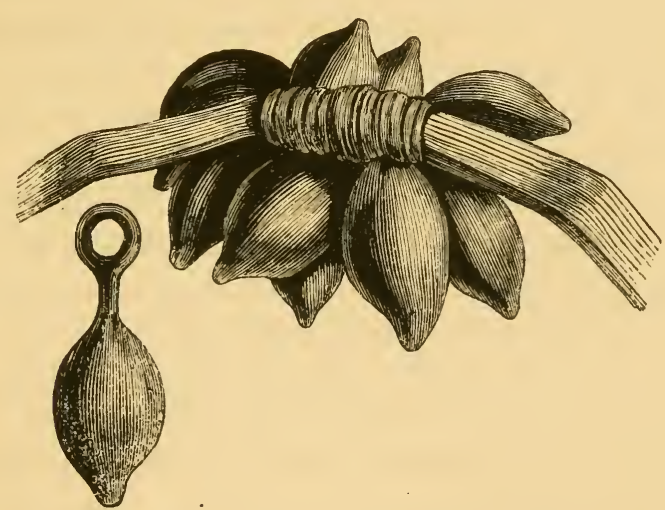

Fig. 10. Eggs of the common Cuttle-fish (Sepia officinalis).

base of the stalk, close to the egg, and cements or welds it there into a solid ring. Thus the eggs are attached, one by one. Sometimes the stalk of one is fastened round that of another, and occasionally the process is repeated until the whole mass is made up in this way, without any central stem. The work is as well and neatly done as if skilled hands had been employed on it, but how the mother cuttle-fish effects it, I believe no one knows. I hope we may some day have opportunities of watching her.

Aristotle wrote that the Sepia fastens her eggs, near land, upon

- See page 93 . 
seaweeds, reeds, and other bodies which may be found on the shore, and even around sticks and faggots placed there for the purpose of entrapping her. "She does not lay them all at once," he says, "but at several intervals, the operation lasting fifteen days; and after the oviposit is completed she sheds her ink upon them, which turns them from white to black, and causes them to increase in bulk." $\mathrm{He}$ also avers that she hatches them in the place where she has deposited them, and is often to be seen with her body resting on the ground, and covering them. I do not think that the dark hue of the membranous integuments of the eggs, and of their pedicle, or foot-stalk, is in any way attributable to their being stained by the animal's inky secretion, although I have frequently seen masses of these eggs the integument of which was not black, but perfectly colourless and pellucid. That the mother broods over them, and protects them till they are hatched, is quite in accordance with the observed habits of the octopus, and is, therefore, not improbable. But, as with the octopus, I am satisfied that no incubation takes place.

At intervals, for many years past, I have found the eggs of the Scpia and Loligo in early stages of their development, and have hatched them out, without any assistance from their parent, by merely suspending them in sea-water in a tank or tub, and changing the water frequently. The same also has been frequently done at the Brighton Aquarium. This having been proved and demonstrated by actual experiment, it is unnecessary to fortify facts by reasoning. But I have seen a branch of a tree or shrub, measuring more than two feet in height from the base of the broken stem to the upper part of its branches, and fourteen inches from side to side across the tips of the twigs, covered with the eggs of Sefic in single rows along them. I cannot of course, be certain that these were all laid by one female, but it is evident that one could not cover so great an area continuously as an incubator, and that, if it were possible, she would subject herself to unnecessary toil in so doing, seeing that they were all hatched 
in a tank, after having been for about ten days deprived of maternal care.

The young Sepia when born is much larger than a baby octopus or squid. It is of about the size of a rather small horsebean. When about half developed, the little animal has the head and eyes disproportionately large, but gradually acquires a greater resemblance to its parent. If the black integument be removed, as one would skin a grape, it may be seen moving in the fluid which fills the egg. Cut clown to the little living grape-stone under water, and away it will swim, with all its wits about it, and in possession of all its faculties, with as much facility and selfpossession as if it had considerable knowledge of the world. It sees and avoids every obstacle, and if you take it out of the water, in your hand, the precocious little creature, not a minute old, and not sufficiently matured to leave the egg naturally, will spurt its ink all over your fingers. You may tame an old cuttle-fish, and it will learn to know that you are a friend, and intend to do it no harm; but the youngsters are as shy as human babies, and regard every one but their mother as an enemy.

The preference for the light, which I described as exhibited by the young octopus, appears to be common also to the young squid and cuttle-fish. The latter generally seek the surface of the water; sometimes swimming gently by means of the locomotive tube and the undulating movement of the marginal fins, and at others poising their bodies motionless, as if basking The habit in these two families is not so surprising as it is in the young octopus, because the adult Scpia and Loligo are not cave-dwellers, but frequent the open sea, and often approach the surface.

The spawn of the squid (Loligo inlgaris) consists of dozens of semi-transparent, gelatinous, slender, cylindrical sheaths, about four or five inches long, each containing many ova embedded in it, and all springing from one common centre, and resembling a mop without a handle. Johann Bodasch, Professor of Natural 
History at Prague,* calculated that one of these mop-like masses contained 39,766 ova; and by counting those embedded in ten of the long gelatinous, finger-like processes, and weighing them and the remainder, I have verified his estimate, and computed that

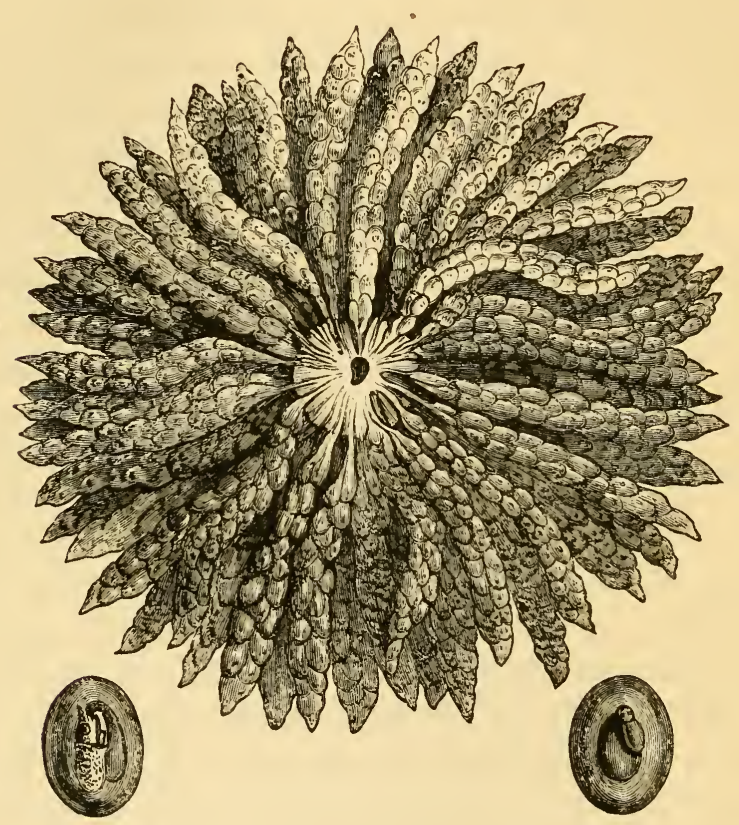

Fig. Ir. Spawn of the common Squid (Loligovnlgaris).

in the specimen which was the subject of my investigation there were 42,000 perfect young squids. It is evident that comparatively few of them live to arrive at maturity, or the sea would teem with them; and in every existing aquarium it has been found impossible to rear the young cephalopods hatched there. I have never seen these "sea-mops" attached to anything, and the pelagic

* De quibusdam animalibus marinis. $176 \mathbf{r}$. 
habits of the calamaries render it probable that they are left floating on the surface of the sea.

A remarkable organ with which some of the cephalopoda are provided is a sac, popularly called the "ink-bag," in which is stored a deep black secretion, which they are able to employ at will as a protection from rapacious enemies. On the approach of a suspected foe, the animal discharges a quantity of this dense fluid, which renders turbid the surrounding water, and thus enables its owner to escape in the obscurity. There is a communication between this ink-bag and the funnel or locomotor-tube, already described; so that when the ink is ejected, it is forcibly emitted with the stream of water which produces its rocket-like, backward motion. The very effort for escape thus serves the double purpose of propelling the creature away from the danger, and discolouring the water in which it moves.

Oppian has well described this :-

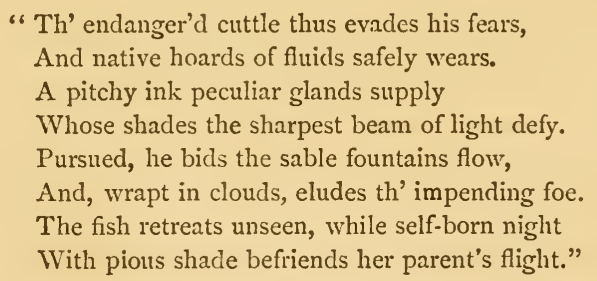

The position of the ink-bag varies in different families. In the octopus it is buried in the substance of the liver; and this animal does not emit its ink so readily as the cuttle or squid. I have very rarely seen it do so in captivity except when greatly exhausted or persistently irritated. It has been said that after being a few hours in captivity the octopus loses the power of secreting ink. There is no foundation at all for such a statement. When placed in a tank especially reserved for it, in which are no enemies to cause it fear, it has no neefd to conceal itself, and therefore does not unnecessarily eject its cloudy fluid; but I have never dissected 
an octopus, no matter how long it might have lived in confinement, without finding the ink-bag fairly charged, though some of its contents are sometimes emitted when the animal is at the point of death.

The cuttle (Sepia) discharges it on the slightest provocation; and this is sometimes very troublesome and annoying when this species is exhibited in an aquarium. The quantity of water its ink will obscure is really surprising. The fluid is secreted with amazing rapidity, and the black ejection frequently occurs several times in succession. I have often seen a cuttle completely spoil in a few seconds all the water in a tank containing a thousand gallons.

When first taken, the Sepia is most sensitively timid. Its keen, unwinking eye watches for, and perceives the slightest movement of its captor ; and if even most cautiously looked at from above, its ink is belched forth in eddying volumes, rolling over and over like the smoke which follows the discharge of a great gun from a ship's port, and mixes with marvellous rapidity with the water, whilst the animal simultaneously recedes to the best shelter it can find.

But, like all of its class, the Sepia is very intelligent. It soon learns to discriminate between friend and foe, and ultimately becomes very tame, and ceases to shoot its ink, unless it be teased and excited.

Professor Owen has remarked that the ejection of the ink of the cephalopods serves by its colour as a means of defence, as corresponding secretions in some of the mammalia by their odour.

It is worthy of notice that the Pearly Nautilus and the allied fossil forms are without this means of concealment, which their strong external shells renders unnecessary for their protection.

Fishermen are well acquainted with the fact that the cephalopods -at any rate, our British representatives of the Sepiida, Calamarics, and Octopoda-habitually discharge, when taken, a jet of water, and the two former sometimes their ink, in the faces of their captors. It has been regarded as doubtful whether this is an intentional act, or whether it is accidental, and consequent on 
the bringing of the orifice of the syphon tube above the surface, and the removal of the resistance to the out-pouring current, which, when ejected under water, would, in the one case, have been a means of locomotion, and, in the other, of concealment of their whereabouts. Some have supposed that the emission is involuntary, and is produced much in the same way as the water is tossed up in spray by the screw of a steam-vessel when her stern rises whilst she is pitching heavily in a rough sea. Others, who have experienced the effect of this habit of the animals, have persistently asserted that they take deliberate aim, with the motive of aggression or self-defence.

Mr. Darwin, in his narrative of the "Voyage of the Beagle," says that whilst looking for marine animals, with his head about two feet above the rocky shore, he was more than once saluted by a jet of water accompanied by a slight grating noise. At first he could not think what it was; but he afterwards found that it was an octopus, which, though concealed in a hole, thus led him to its discovery; and it appeared to him that it could certainly take good aim, by directing the tube or syphon on the under side of its body.

The force with which the water is expelled is often very great. Some of the Loligince are capable of propelling themselves with such momentum by a vigorous out-rush from the tube, that when this pressure is so exerted as to cause them to take an upward direction, they leap out of water to such a height as to fall on to the decks of vessels, and are called by sailors "flying squids." Desiring to preserve some specimens of the "little squid" (Loligo media), if possible with their colours unchanged, I put two alive into a bottleful of spirits of wine as the best method of causing their instantaneous death. Both of them immediately "squirted" with such effect that a third part of the spirits of wine was thrown out of the bottle and spilled on the table.

I have no doubt at all that the cephalopods intentionally and deliberately take aim, and that they are able to do so as accu- 
rately as the "Archer-fish" (Toxotes jaculator), which by the ejection of a drop of water from its mouth, brings down a fly from a branch or leaf three or four feet above the surface of the water.

With the purpose of testing the swimming powers of an octopus, and making other observations connected with its mode of progression through the water, I experimented with one in one of the store tanks at Brighton. I had put him through his paces, and brought him back to the starting-post several times after he had swum to the further end of the tank, and at last the creature became irritated. Instead of sinking to the bottom as he had previously tried to do, he swam along the surface away from me till he reached the back of the tank, where he sustained himself motionless for an instant, and then shot forth a jet of water which struck me on the breast, and drenched my shirt-front, though I was five feet distant from him.

I have known of many amusing instances of this squirting of water or ink by the cuttle-fish startling the victim of it by its unexpected suddenness.

My deceased friend Tom Hood, unaware of this propensity of the animal, hastened to lay hold of one which he had hooked in Looe Harbour, and, receiving its jet d'cau full in his face, exclaimed that "he did not exactly know what he had on his line, but he thought he had caught a young garden engine."

Fishermen, when catching squid as bait, haul them up slowly until they are nearly at the surface of the water, and then "gaff" them by the tail, and hold them at some distance from the boat, to allow them to discharge their ink. The Rev. J. G Wood mentions an incident of a naval officer's white-duck trousers being "de-decorated" with the liquid missile of a cuttle; the aggrieved individual asserting that it took deliberate aim for that purpose.

During a Saturday night's chat with some Sussex fishermen with whom I had often before held pleasant conversation on matters appertaining to their craft, cuttle-fishes, sometimes called by sailors "ink-spewers," were mentioned, and one of the party 
related the following adventure of a shipmate who was present. I must tell it in his own language.

"We was out fishin' one quiet night," he said, "and had just got our trawl awash, and was a-goin' to hand it in-board, when Bill, here, all of a sudden lets go his holt, roars out like a stuck pig- "Oh-h-h! - What the — is that?" and tumbles back'ards into an empty fish-basket. We hadn't no time to 'tend to him till we'd got our haul on deck, but I guessed what was up; and when we looked round we pretty near split our sides with laughing. There was Bill a-leanin' back agin the skiff, wipin' his eyes, to get some muck out of 'em, as he said made 'em smart, and his face for all the world as if Davy Jones had emptied a tar-barrel on his head, and he looking as doleful as a schoolboy as has upset the inkstand over his hands and smeared his face with it in rubbin' the tears away while he was a-crying for fear the master'd lick him. Well, sir, it were one o' them scuttles as we're talkin' about as we'd brought up, and they can shoot straight and no mistake. It's my opinion as Mr. Scuttle sighted Bill's nose as soon as he come atop of the water and aimed right at it; for you can see, sir, as Bill's nose looms as red as Beachy Head Light in a fog, and any scuttle as misses it must be a focl. Bill won't forget that dose of ink for a good while yet-will 'ee, old man?"

Bill is very good natured, and joined heartily in the laugh elicited by the anecdote. The worthy fellow might have retorted that he had seen his friend's face, and those of half the population of his neighbourhood simultaneously blackened, if not by a cuttlefish, by an equally singular accident.

In the autumn of 1872 , an American full-rigged ship, bound to London, went ashore in Seaford Bay, in consequence of the captain mistaking the lights and (believing himself further up Channel) pointing her head N.E. before he ought to have done so. The vessel was lightly built-a mere bandbox of a craftand, after beating and thumping for a short time close in shore, she became a total wreck. The masts went by the board, and, as 
she broke up, the sewing-machines, metal pails, and other "Yankee notions" with which she had been laden, were rolled and tumbled on the beach by the breakers in a pitiable condition and sad confusion. Amongst her cargo were a hundred casks of lampblack; and at intervals one and another of these would burst with a crash, and the contents fly out in clouds, like smoke from a gun. The soft impalpable powder did not mix readily with the water, and was carried to the shore and inland by the strong seabreeze. The coast-guards' white buildings gradually assumed the hue of the inside of a boiler-flue; the beach, the grass, and the roads in the vicinity looked as if fifty thousand chimney-sweeps had emptied their soot-bags over them; and the stuff fell lightly and gently, like a dust shower, over the throng of anxious spectators, until the ladies appeared as if they were dressed in deep mourning for the catastrophe, and the faces of all, moistened by the salt spray, and bespattered and powdered with the subtle material, became as black as a negro's, and as shiny as a wellblacked stove. A visitor arriving suddenly amongst them, without access to a looking-glass, might well have believed that he had discovered a colony of panic-stricken Christy minstrels. The sublime, the sorrowful, and the ridiculous have, perhaps, never beer more intimately blended than in that scene of dashing, foaming breakers, tossed and battered wreckage, and smutted faces. Even Denys De Montfort's "colossal poulpe," which he described as deluging a ship from its syphon tube, would not have had an inkbag large enough to produce such an effect by its contents. 


\section{CHAPTER IX.}

ECONOMIC VALUE OF CUTTLE-FISHES.

I WILL now try to answer M. Hugo's question concerning " these blasphemies of creation against itself" - "Of what use are such creatures? What purpose do they serve?"

It must not be supposed that in mentioning a few facts relative to their economic value to mankind I consent to the narrow and conceited doctrine that, either by laws fixed from the beginning, or by successive fiats of creation, they were especially provided for the future advantage of the human race. Many genera of them, which formed no unimportant portion of the fauna of the ancient seas, lived and died, and their families became extinct, ages upon ages before man's appearance on the earth. He has, it is true, utilised them to a certain extent, and in various ways. In some parts of the world they are a recognised addition to the food supply of the population; and, in others, the means by which fishes more valuable than themselves are obtained, and become marketable produce. But that this is the sole object of their being, I cannot for a moment suppose; and therefore I am content to believe that the Great Architect of the Universe made them and all things for Himself, and that for His pleasure they are and were created.

Although the cephalopods are seldom eaten in Great Britain, they are appreciated as food by nearly all other maritime nations. Along the western coast of France, and in the countries bordering on the Mediterranean and Adriatic, they form a portion of the habitual sustenance of the people, and are regularly exposed for sale in the markets, both in a fresh and dried condition. Salted 
cuttles and octopus are there eaten during Lent as commonly as salted cod are brought to table in England on Good Friday; and, thus prepared, generally form a portion of the provisions supplied to the Greek fishing-boats and coasters.* The Indians of North-

* The following interesting information, which appeared in the Standard of December $25_{\text {th, }} \mathbf{1 8 7 4}$, is derived from a Report on the Tunisian Fisheries by Mr. W. Kirby Green, H.B.M. Consul at Tunis, published in May, 1872 .

"During Advent and Lent, the octopus is largely consumed by the Orthodox Greek Catholics, amongst whom the use of meat and fish is prohibited in those seasons of abstinence. This strange diet is chiefly obtained from Tunis, and in the Levant and Greek markets its trade name is "octopodia" or "polpi." The villages in the neighbourhood of Karkenah are the chief localities where this species of cephalopoda are obtained, and the produce of this fishery, in a year of abundance, yields about $2,500 \mathrm{cwt}$. of polypi ; in an average year, about $\mathrm{I}, 800 \mathrm{cwt}$. ; in a year of scarcity, $\mathrm{I}, 050 \mathrm{cwt}$. In a good season the whole of the Island of Karkenah supplies about 3,000 cwt.; and the Jerbah waters a third of this quantity. On the shores from the village of Luesa to that of Chneies, in the Gulph of Khabs, the natives collect from four to five cwt. of octopods a day during the season; but this supply generally serves for the consumption of the Regency. The remaining coast and islands may be calculated to furnish a minimum of $650 \mathrm{cwt}$. to $700 \mathrm{cwt}$. of dried fish.

The octopods prefer the rocky shallows, and are found in those waters, coming from the open sea, in the months of January, February, and March; but a considerable number remain permanently near the shore. It has been observed that when their fry are numerous from the months of June to August, the fishery of the coming season is sure to be abundant, whilst the reverse is the case if they appear in numbers in November and December. On the arrival of the octopods in the shallows they keep in masses or shoals, but speedily separate in search of shelter among the rocks near the beach, covered by only one or two feet of water, and in stony localities prepared for them by the fishermen, in order to facilitate the depositing of their spawn.

In deep water they are taken by means of earthen jars strung together and lowered to the bottom of the sea, where they are allowed to remain for a certain number of hours, and into which the fish introduce themselves. Frequently from eight to ten octopods are taken from every jar at each visit of the fishermen. In less deep water earthenware drain pipes are placed side by side for distances frequently exceeding half a mile in length, and in these also the octopods enter, and are subsequently captured. As they are attracted by all white, smooth, and bright substances, the natives deck places in the creek, and hollows of the rocks with white stones and shells, over which the polypi spread themselves, and so are caught from four up to eight at a time. But the most successful manner of securing these fish is pursued by the inhabitants of 


\section{Western America look upon them as the proverbial alderman} regards turtle, and devour them with the same gusto and relish;

Karkenah, who form long lanes and labyrinths in the shallows by planting the butt ends of palm branches at short distances from each other, and these constructions extend over spaces of two or more miles. On the ebb of the tides which in the Little Syrtis is considerable (ten feet), thus differing from the rest of the Mediterranean, the octopods are found in the pools inside the inclosures, and are easily collected by the fishermen, who string them in bunches, called "risma," and from eight to ten of these, each containing 50 fish, are secured daily through the season by every boat's crew of four men. The produce of this fishery could apparently be considerably augmented by the increased construction of palm butt labyrinths, whick appear to have a peculiar attraction for the polypi, but it is doubtful whether the demand for octopods is capable of further development, for the consumption of this product is restricted to the countries where the rigours of the fast of the Orthodox Greek Church are still observed.

The Tunisian Government claims a third of all the polypi fished upon its coast. The native fishermen, in general, sell their octopods to the merchants in anticipation, the latter making them pecuniary advances, four or five months before the season, at a stipulated price for the fish, which is seldom, however, below 20s. the cwt. Should the fishermen fail to supply the quantity contracted for, the merchant is entitled to demand that they should procure for him the requisite weight of fish elsewhere; but this power is rarely enforced, a new agreement being more frequently entered into for the coming season, on proportionately favourable terms for the purchaser. Another practice is also followed for the purchase of octopods. The merchant makes an advance to the fishermen a month before the season, and receives back the value of his money at the first public sale, at the current price, with an addition in his favour of 5 per cent. on the amount disbursed.

The octopus has hitherto been prepared for exportation by simply salting and drying, but it is now preserved either in oil or brine, after subjecting it to a preliminary scouring and boiling process.

The price for octopods varies considerably, according to the size, supply, and demand ; but at Sfax a pair of fresh fish may cost, as circumstances rule, from $6 d$. to $1 s .3 d$. However, the preparatory maceration, by beating on a stone slab or rock, required before drying, entails a small additional expense, and brings the extremes of low and high prices to 25 s. or 50 s. per cwt. To the cost price must be added an export duty of 5 s. 1 d., and the purchaser ought to be careful to receive his merchandise from the seller during dry weather, as a damp day will add from 4 to 5 per cent. to the weight of every cwt.

Malta receives the largest part of the Tunisian octopods, but they are only sent to that island for ultimate transmission to Greece and other parts of the Levant. Portugal is one of the few countries that competes with Tunis in 
only the savage roasts the glutinous carcase, instead of making soup of it. In Chili, Peru, Brazil, and Teneriffe, they are eagerly sought for; and they are an article of daily consumption in India and China, and especially in Japan, where there is a very important trade in them. Professor Edward Forbes* relates his experience of the use of them by the Greeks :-

"The traveller who, when treading the shores of the coasts and islands of the Egean, observes, as he can scarcely fail to do, the innumerable remains of the hard parts of cuttle-fishes piled literally in heaps along the sands-or, when watching the Greek fishermen draw their nets, marks the number of these creatures mixed up with the abundance of true fishes taken and equally prized as articles of food by the captors-can at once understand why the naturalists of ancient Greece should have treated so fully of the history of the cephalopoda, and its poets have made allusions to them as familiar objects. One of the most striking spectacles at night on the coasts of the Egean is to see the numerous torches glancing along the shores, and reflected by the still and clear sea, borne by poor fishermen paddling as silently as possible over the rocky shallows in search of the cuttle-fish, which, when seen lying beneath the waters in wait for his prey, they dexterously spear, ere the creature has time to dart with the rapidity of an arrow from the weapon about to transfix his soft but firm body. As in ancient times, these molluscs constitute, now, a valuable part of the food of the poor, by whom they are chiefly used. We can ourselves bear testimony to their excellence. When well beaten, to render the flesh tender, before being dressed, and then cut up into morsels and served in a savoury

supplying the Greek markets with polypi. In Greece, the octopods are either sold after being pickled, at from $£ 1216 s$. to $£_{15} 9 s$. the cantar of $176 \mathrm{lb}$., or in their original dried state at from $£ \mathrm{I} 2$ to $£ \mathrm{I} 4$, but it must be understood that these prices are subject to considerable fluctuations arising from the favourable or unfavourable state of the season's fishery.

* Travels in Lycia ; by Lieut. (now Admiral) A. B. Spratt, R.N., F.G.S., and Professor Edward Forbes, F.R.S. 
brown stew, they make a dish by no means to be despised, excellent in both substance and flavour. A modern Lycian dinner, in which stewed cuttle-fish formed the first, and roast porcupine the second course, would scarcely fail to be relished by an unprejudiced epicure in search of novelty."

I have tasted the octopus, sepia, and loligo, and am quite of Professor Forbes's opinion that they are very palatable when really well cooked. 'They are all the better for being dressed with made gravy, but may be eaten plainly boiled, and served with egg-sauce. They are apt, however, to be very tough unless slowly simmered, and should first be well beaten with a wooden mallet or the flat of a cleaver. At Gibraltar, the Spanish fishermen may frequently be observed engaged in softening an octopus by dashing it several times with great violence on the stone landing steps at the fish-market.* The flavour is not unlike that of the skate, or the white part of a scallop. A writer in the "Echo" called the flesh of the octopus "a sort of marine tripe, the chief merit of which lay in the sauce in which it was served." I am inclined to agree with him.

- The special correspondent at Gibraltar of the Daily Telegrapin (Mr. George Augustus Sala) wrote as follows on this subject :-For the information of Mr. Henry Lee, I may observe that nothing whatever is known at Gib. about the terrible octopus who is said to have sucked the boatswain of a man-of-war into the lowermost depths of Davy Jones's locker ; but there are legends commonly recited in the smoking-room of the King's Arms as to an octopus that held on to a sharp rock with one set of suckers, and capsized a felucca from Algeciras with the other. The Spaniards eat this horrible creature very willingly. When they catch him, they first pound him violently between two stones, as some cooks are in the habit of thwacking beefsteaks of which the tenderness is doubtful, and then they hang him up in the sun until his abominable body and limbs are dried. Ultimately they fry him in oil, and declare that he is very nice. I have an idea that I must have eaten fried octopus for supper at Bobadilla, and that it was the delicacy which gave me such a thorough disgust of the place. The octopus, nevertheless, under the name of pulpo, is popular enough throughout Southern Spain, and is equally common, and equally devoured, on the coast of Algeria and Morocco.-Daily Talegraph, March 15, 1875 . 
To many persons who have not, like the Greeks, been accustomed from childhood to regard it as a delicacy, the appearance of an octopus, alive or dead, is very revolting; and I admit that its boiled carcase, put before one in unadorned simplicity, is not appetizing.

I shall never forget the utter loathing, ludicrously mingled with determination to conquer or conceal that feeling, which was depicted on the countenances of some of the guests at a memorable "octopus-lunch" given by my friend Sir John Cordy Burrows at Brighton, in 1874 .

His cook had never before prepared an octopus, and was, probably, not well pleased to do so then. The nasty-looking object was placed on the table in all its undisguised ugliness. Its skin, which in the process of boiling had become lividly purple, and had not been removed, was in places offensively broken and abraded; and its arms, shrivelled and shrunk, sprawled helplessly on the dish, and, somehow, looked, as they proved to be, as tough and ropy as so many thongs of hunting-whips. Our genial host saw in an instant that it was a failure in cookery, but, as usual, he was equal to the occasion. With a twinkle of his eye he "took a sly glance at me," and gravely handed a portion of the octopus to an honoured guest. "Now, sir," said he, "just taste that, and enjoy one of the luxuries of the ancient Greeks!" The ancient Greeks were, as it seemed to me, mentally anathematized; but the plate was accepted, its contents earnestly scanned, the knife and fork just brought into contact with the viand, and then all were thrust hastily away. A gallant colonel, who would probably be in "the first flight" across country, and would not hesitate to lead a charge of his regiment, also "craned" at his plate, and declined to taste the "luxury." Sir Cordy then looked to me as his "forlorn hope." With the air of a veteran and connoisseur I helped him and myself to some of the most approved portions of the leathery creature. Manfully and perseveringly for some $\mathrm{n}$ inutes I tried to masticate a mouthful of it, but it was useless; 
and feeling that if human teeth could make no more impression on it than on the sole of an old boot, the human stomach incurred risk of difficulties which all the well-known medical skill of our good host might be unable to cure, I declined to sacrifice myself to an idea, and -

The octopus had not been beaten. We were! I afterwards saw this little private experiment seriously described in a newspaper paragraph, which was extensively quoted, as an endeavour to introduce to the public a new and valuable article of marketable food.

In my opinion, the squid, or sleeve (Loligo), is the best of the three. Rondeletius recommends their being dressed with oil and vinegar. On the Normandy coast they are boiled with onions and other vegetables, the liquor being saved as good stock for soup. At Marseilles they are stuffed with dried tendrils of the vine. The Chinese and Japanese prefer them seasoned with vinegar and ginger, and attribute to the flesh various medicinal properties. In Mauritius and the neighbouring islands they are generally curried.

The various genera of cuttle-fishes were held in high estimation by the ancients; and it was a custom of the Greeks to send them out as presents on the fifth day after the birth of a child, and before giving it a name. At the nuptial feast of Iphicrates, who married the daughter of Cotys, King of Thrace, a hundred polypi and sepiæ were served. The Greek epicures prized them most when they contained "roe," and had them cooked with highly seasoned sauces. The Lacedæmonians boiled them entire, and were not disgusted by the black froth formed by their inky liquor diffusing itself in the water.

In "The Deipnosophists" of Athenæus are numerous quotations from older writers relating to the use, as food, of the various kinds of cuttle-fishes. Athenæus, who was an Egyptian, born in Naucratis, a town on the left side of the Canopic mouth of the Nile, lived and wrote in the first half of the third century. $\mathrm{He}$ appears to have been imbued with a great love of learning, in the pursuit of which he indulged in the most extensive and 
multifarious reading. His "common-place book" must have been a marvel of industrious annotation and careful record, for he has saved from oblivion, by his extracts from their writings, many authors whose works have been long ago lost, and of whose existence future generations would have been unaware, if he, by his faithful and painstaking acknowledgment of his indebtedness to them, had not handed them down to posterity. He devotes many chapters to the history of festive entertainments, and the dishes served at banquets of the old Romans and Greeks; and by his collection from numerous authors of passages, some of which contain but a few words, and were probably regarded by their contemporaries as of fugitive interest, has given us an insight of the elaborate preparations made for dinner-parties, and the appreciation of artistic cookery by gourmets in those days. Some. of our household cooks in this nineteenth century would "give warning " instantly if asked to get ready for table for their master's friends such a profuse variety of dishes. Course followed course in skilfully arranged sequence, all intended to tempt the palate, or supposed to possess some medicinal or stomachic virtue, and presenting, in their combination, a feast compared with which our lord mayor's dinners are unrefined in their mere plenty. In all important entertainments, public or private, the cuttle-fishes of the Mediterranean were highly esteemed as delicacies, and were as well known and regularly looked for in the menu as are salmon and turbot at similar gatherings now. In the following extracts from the notebook of Athenæus, by the "polypus" is meant the Octopus, by the "cuttle-fish" the Sepia, and by the "squid" or "squill," the genus represented by our Loligo.

Plato, the comic poet, mentioning in his "Phaon" the banquet of Philoxenus the Leucadian, says :--

"Good-sized polypus in season, Should be boiled-to roast them's treason, But if early, and not big, Roast them ; boiled ar'n't worth a fig." 
Alexis, in his "Pseudypobolemæus," writes :-

Take the stiff feelers of the polypus,

And with them you shall find some modest liver

And cutlets of wild goats, which you shall eat.

The eggs of the octopus and sepia were also regarded as dainties. Hegemon of Thasos thus refers to them in his "Philuma:"-

Go quickly ! buy me of that polypus,

And fry the roe, and give it us to eat.

But to fry octopus was not, by some, considered good cooking. Nicostratus of Philetærus says, in the "Antyllus :"-

I never again will venture to eat cuttle-fish which has been dressẹd in a frying-pan.

They ate heartily at breakfast in those times, it seems, for Epicharmus tells us in "The Sirens:"-

In the morning early, at the break of day,

We roasted plump anchovies,

Cutlets of well-fed pork and poi'ypi;

And then we drank sweet wine.

Philoxenus, the poet of Cythera, is reported to have been a very greedy man. He wished that he had a throat three cubits long, that he might drink as long as possible, and that his food might all at once delight him. Machon, the comic poet, relates how his fondness for well-cooked octopus and his insatiate gluttony caused his death :-

They say Philoxenus, the ancient poet

Of Dithyrambics, was so wonderfully

Attached to fish, that once at Syracuse

He bought a polypus two cubits long,

Then dress'd it, and then ate it up himself,

All but the head-and afterwards fell sick,

Seized with a sharp attack of incligestion.

Then when some doctor came to him to see him 
Who saw that he was greatly out of order;

"If," said the doctor, "you have any business

Not well arranged, do not delay to settle it,

For you will die before six hours are over !"

Philoxenus replied, "All my affairs,

O Doctor, are well ended and arranged

Long, long ago; but now, since deadly fate

Calls me awvay, who can't be disobeyed,

That I may go below with all my goods,

Bring me the relics of that polypus!"

We learn something of the most approved methods of cooking the "cuttle-fishes" and "squids" from the following passages. Sotades, in his play entitled "The Shut-up Women," introduces a cook, who makes a speech in which these molluscs are mentioned :-

A fine dish is the squill, when carefully cook'd,

But the rich cuttle-fish is eaten plain ;

Though I did stuff them all with a rich forced-meat

Of almost every kind of herb and flower.

Alexis, in his "Wicked Woman," also introduces a cook, who speaks as follows :-

Now these three cuttle-fish I have just bought

For one small drachma. And when I've cut off

Their feelers and their fins, I then shall boil them;

And, cutting up the main part of their meat

Into small discs, and rubbing in some salt,

After the guests already are sat down

I then shall put them in the frying-pan,

And serve up hot towards the end of supper.

Eriphus says, in his "Melibœa :" -

These things poor men cannot afford to buy ; -

The entrails of the tunny, or the head

Of greedy pike, or conger, or cuttle-fish,

Which I don't think the gods above despise.

Athenæus cites a great many more authors, who testify to the esteem in which the cephalopoda were held in the olden times, as the constituents of dainty dishes. 
Cuttle-fishes are employed as bait by fishermen, and, by their abundance at certain seasons in the neighbourhood of Newfoundland, they exercise an important influence on the cod-fishery; thus playing, as D'Orbigny remarks, an important part in the commerce of the most flourishing nations of Europe.

From a letter from Mr. W. E. Cormack, an intelligent Newfoundland merchant, who distinguished himself by being the first European who succeeded in crossing Newfoundland-communicated by Professor Jameson to the "Edinburgh New Philosophical Journal" (I \&26, p. 32)-we learn that more than a hundred millions of cod are caught annually with cuttle-fish as bait, about two hundred millions with the capelin, and one hundred millions with herrings and "shell-fish."

Poole, in Dorsetshire, has long been one of the principal ports and depôts of the Newfoundland trade. My friend Mr. Wm. Penney of that town, very kindly obtained for me, in compliance with my request, some authentic recent information on the subject from a gentleman who for many years resided in Newfoundland, as the agent of a Poole firm. He writes :-

"My friend Mr. E—, who has opent some years in Newfoundland, informs me that the bait used for the cod-fishery there at the commencement of May is the herring; during June, July, and August, the capelin; and about the end of August, and throughout September they use the squids, which come into the bays in great abundance. They are caught by means of a "jigger," which is a conical piece of lead, round the circumference of the base of which are inserted eight or ten hooks. The fishermen go out in punts squid-jigging of an evening, to catch the bait required for the next day's fishing. About roo or more squids are caught by each boat, and thousands of them are taken during the season about 150 or 200 yards from the shore, in tolerably deep water. In many stations more than a dozen boats are engaged in squid-catching. During the squid-jigging the fishermen hollo and shout, and make a great noise; for what purpose 
Mr. E- does not know. All parts of the squid are cut up, and used as bait; what is not required the next day is thrown away or given to the pigs. In the northern district, hetween Cape Freels and Cape St. John, the fishing spots are at Robin's Cave Head, and Friday's Bay, on the anchorage ground. The fishing takes place about sun-down. The squid is of an oval form, and resembles somewhat our cuttle-fish, but it has no solid bone. The length of the body is from eight inches to a foot, and it is about two inches in diameter. The flesh is said by the fishermen to be remarkably sweet and good eating, and to be excellent fried. About the end of September the squid disappears, and herring are then again caught : thus herring forms the bait for the fishery at the commencement and end of the fishing season. Mr. $\mathrm{E}$ - believes that the squid is caught and used for bait all round Newfoundland, but he can only speak with certainty of the northern district."

I learn from other sources that the same mode of fishing is followed in other parts of Newfoundland, and that hundreds of boats are engaged during September in "jigging;" a crew of three men usually taking from one hundred to five hundred in a day.. The squids come into the bays in such vast shoals that sometimes, during violent gales, hundreds of tons of them are thrown up together in beds on the flat beaches, and their decay spreads an intolerable effluvium around.*

The Greek fishermen use, as a "jigger," the bone of the Sepia surrounded with hooks, believing it to be more attractive than the leaden weight above described.

* A gentleman engaged in the cod fishery, and residing at Fogo, Newfoundland, has told me that he was startled one evening by an unusual sound at the back of his house, which is at the head of the harbour, and the next morning found three barrels of squids dead on the shore. The same gentleman received information, on the 29 th of June, 1873 , of a gigantic squid having been picked up in Trinity Bay, and seen by Mr. Haddon, school inspector. It measured sixteen feet in length. The squid used so abundantly as bait in the Newfoundland cod-fishery is Ommastrephes sagittatus. 
This mode of catching squid is of very early origin. It was a common practice in Oppian's time, although the "jigger" he describes was somewhat different from that now in use. $\mathrm{He}$ writes :-

For sleves a slender shaft the swain provides

Cylindric, like a distaff : round the sides

Adjacent hooks their radiant files extend,

With points supine the dreadful rows descend,

To silent deeps the fatal engine slides,

The steely curves a painted rainbow hides.

The incurious sleve invades his artful fate,

And throws his branching snouts around the bait.

Within the hooks the thready tendrils twine,

Entangled in th' embrace they would resign.

In vain to disengage his hold he tries,

In his own chains the self-caught captive dies.

Oppian also describes another method of taking cuttles, which in some localities is still resorted to at certain seasons. The fishermen fasten the end of a line round a living female octopus or sepia, and lower her down towards a rocky bottom. On the male coming to woo he comes to woe, for both are pulled up together.

There is nothing incredible in this. The Japanese, at the present day, use a spawning female fish as a lure for others of the same species. Having found one nearly, but not quite, ready to deposit her roe, they squeeze from her a portion of it, which hangs suspended from the body, and then anchor her near the shore by a hook and line. The males are instinctively drawn to the spot, a seine is shot round them, and all are easily taken. A similar process is commonly resorted to by entomologists for the capture of rare species of moths and butterflies.

Cuttles are often caught in the Adriatic by sinking in the sea branches of trees and faggots, which entice them, as being suitable spawning ground and offering good anchorage for their eggs.

It is somewhat remarkable that whilst the octopus shuns the light and retreats from that of a lanthorn, the cuttle and sciuid are 
attracted by it. At Trincomalee, at certain seasons of the year, the bay is illuminated during the night by hundreds of lights of fishing boats moving hither and thither. A dead cuttle is generally the bait used. This is suspended in the water, and when hauled in from time to time, one or more of its species are found fast to it, and feeding on their deceased relative. When removed from the water they emit a peculiar "squelching" noise, which has been compared to the grunting of a hog. It appears to me to be caused by the forcing of air, instead of water, through the syphon tube.*

They are also frequently taken by spearing, as described by Edward Forbes; and my friend, Mr. Henry Woodward, F.R.S., mentions $\uparrow$ having seen in a curious Japanese book, preserved in the British Museum, a picture of a man in a boat engaged in catching cuttle-fishes with a spear, and also of a fishmonger's shop in Japan at which a number of enormous cuttle-fishes are represented hanging up for sale.

The crystalline lens of the eye, which is soft in quadrupeds, and cartilaginous in fishes, is very solid in the cephalopoda. It is almost eaicareous, and very peculiar in its form. It consists of two double concave portions, divided by a deep groove, in which are inserted the ciliary processes. The two halves, which are almost globose at their outer surfaces, separate easily, and exhibit internally a series of concentric coats, which reflect light with a

* In Jonathan Couch's manuscript diary, which I have had the gratification of perusing, the following entry appears, dated 1819:- "Joln Hotton (a fisherman of Polperro), informs me that some time since he was at sea for the purpose of catching cuttles, when the night was so dark, that, though cuttles were in plenty and followed the bait to the surface, he could not see to hook them. He then desired his son to take a lanthorn, and hold it close to the water so that he might see; when, to his surprise, a great many cuttles gathered round the light, and without bait or hook he caught eighteen by hooking them with the rod (gaff). Since then he has more than once put the same plan in practice with success."

† "Intellectual Observer," vol. ii., p. I64. 
beautiful nacreous opalescence and play of colours. In some parts of Italy the women use these lenses as beads for necklaces. I have seen them thus worn at Genoa on festival days. They appear also to have been used as ornaments by the ancient Peruvians. Dr. J. E. Gray, in his "Spicilegia Zoologica," published in I828, says that the Rev. Mr. Hennah brought to this country several of a large size which he found in the tombs and old habitations of the natives; and that Mr. Stutchbury had informed him that the Sandwich Islanders sold these lustrous eyes to the Russians as pearls.

The "cuttle-bone" or dorsal plate of Sepia, sometimes called "sea-biscuit," from its shape and its being frequently found floating on the surface of the water, is used, when pounded, as polishing powder, by jewellers, and, under the name of "pounce," to smooth writing-paper where an erasure has been made with a penknife. Known as "white coral powder," it used to be regarded as the very best dentifrice," and was formerly prescribed in medicine as an antacid and absorbent.

The Roman ladies employed it, burned and pulverised, as a cosmetic for the face ; and it was, no doubt, a good substitute for the "pearl powder" now in fashion. Broken pieces of it are also occasionally placed between the wires of the cages of songbirds, for them to peck at, instead of chalk or other calcareous substances.

The "ink" which the cuttle-fish has the power of ejecting when alarmed, for the purpose of obscuring the water and hiding its own retreat, was formerly used in writing. Cicero mentions this use of it, and from it is also made the true "sepia" of artists. I have more than once lately seen it stated that the ink of the cuttle-fish is no longer employed for this purpose, and that "sepia" is now prepared from lamp-black. A great deal of rubbish of this kind is probably sold; but I have recently seen

* One of the recipes for "areca-nut tooth-powder" is :- "Ground arecanuts, three parts ; cuttle bone, one part ; flavour with cloves or cassia." 
at Messrs. Newman's, the well-known artists' colourmen, in Soho Square, thousands of the ink-bags of cuttles in the raw state, ready to be manufactured into "sepia." The fishermen of some of our southern counties, when cleaning cuttles and squids for bait, habitually dry the ink-bags and their contents, and preserve them until Messrs. Newman's agent visits the district and collects them. If the Newfoundland fishermen, when "squid-jigging," would take the trouble to preserve the ink-bags, they would find a ready sale for them, and might make of them a profitable perquisite. The beautiful drawings with which Cuvier illustrated his, "Anatomy of the Mollusca" were executed with the ink which he had collected whilst dissecting many specimens of the cephalopoda; and it is well known that fossil cuttle-fishes have been found with the ink-bag perfect, and that from its contents excellent "sepia" has been obtained. Some of these ink-bags found in the lias, associated with traces of the "pen" or inner shell, are nearly twelve inches long, and must have belonged to calamaries of gigantic size. It is an oft-told anecdote that the late Dr. Buckland gave some of this fossil ink to Sir Francis Chantrey, who pronounced it to be of unusually good quality, and with it made a drawing of the specimen from which it was taken. This drawing is now in the possession of Dean Buckland's son and Sir Francis's godson, my friend Frank Buckland. I have also seen a cake of fossil sepia prepared by Messrs. Newman for Professor Dick, of Cambridge, about the year 1850 , which rubs as smoothly, and is as rich in colour, as that manufactured from the ink of recent cuttlefishes. 


\section{CHAPTER X.}

GIGANTIC CUTTLE-FISHES.

THE history of the ancient belief in the existence of gigantic cephalopods is somewhat obscure. All that we know of it is from passages in the works of a few old Greek and Latin authors, and a series of Scandinavian traditions. I have already referred to the "monstrous polypus" mentioned by Pliny, * which, at Cartoeia, in Grenada, used to come out of the sea at night, and carry off salted tunnies from the curing depôts on the shore, and also to the incident recorded by Ælian, $\uparrow$ who describes his monster as crushing up the barrels of salt-fish in its arms, to get at the contents. In the legends of northern nations stories of the existence of a marine animal of such enormous size that it more resembled an island than an organised being frequently found a place; and though the descriptions given of it were wild and extravagant, it is not difficult to recognise in the ill-drawn and distorted portrait the attempted likeness of one of the cephalopoda. Olaus Magnus relates many wondrous narratives of sea-monsters,--tales which had gathered and accumulated marvels as they were passed on from generation to generation in oral history, and which he took care to bequeath to his successors undeprived of any of their fascination.

Eric Pontoppidan, the younger, Bishop of Bergen, is generally, but unjustly, regarded as the inventor of the fabulous Kraken, and

* "Naturalis Historiæ," lib. ix., cap. 30. A.D. 77 .

† Lib. iii., cap. 6. De anim. A.D. 220 to 250.

\# " Historia de gentibus Septentrionalibus." A.D. 1555 . Olaus Magnus, archdeacon, is frequently mistaken for Johan Magnus, Archbishop of Upsala. 
is constantly misquoted by authors who have never read his work, * and who, one after another, have copied from their predecessors erroneous statements concerning him. More than half a century before him Christian Francis Paullinus, $\uparrow$ a physician and naturalist of Eisenach, who evinced in his writings an admiration of the marvellous rather than of the useful, had described as resembling Gesner's "Heracleoticon," a monstrous animal which occasionally rose from the sea on the coasts of Lapland and Finmark, and which was of such enormous dimensions that a regiment of soldiers could conveniently manœuvre on its back. Pontoppidan was not a fabricator of falsehoods; but, in collecting evidence relating to the "great beasts" living in "the great and wide sea," was influenced, as he tells us, by " a desire to extend the popular knowledge of the glorious works of a beneficent Creator." His fault, or mistake, was that he gave too much credence to old narratives and traditions of floating islands and sea monsters, and to the superstitious beliefs and exaggerated statements of ignorant fishermen. If those who abuse him had lived in his day they would probably have done the same. The tone of his concluding remarks is not that of an intentional deceiver and knave. $\mathrm{He}$ says he "believes the accounts given to be true and well attested," and that he "leaves it to future writers to complete what he has imperfectly sketched out, by further experience, which is always the best instructor." No wonder, therefore, that his evident sincerity and the respectability of episcopal advocacy obtained belief for the fable of the Kraken.

The Norwegian bishop was a conscientious, if over-credulous man: but the same cannot be said of Denys de Montfort, who, half a century later not only professed to believe in the existeltce of the Kraken, but also of another gigantic animal distinct from it; a "colossal poulpc," or octopus, compared with which Pliny's was a mere pigmy. In a drawing fitter to decorate the outside of

* "Natural History of Norway," cap. S. A.D. I754.

* Born I6.43; died I7I2. 


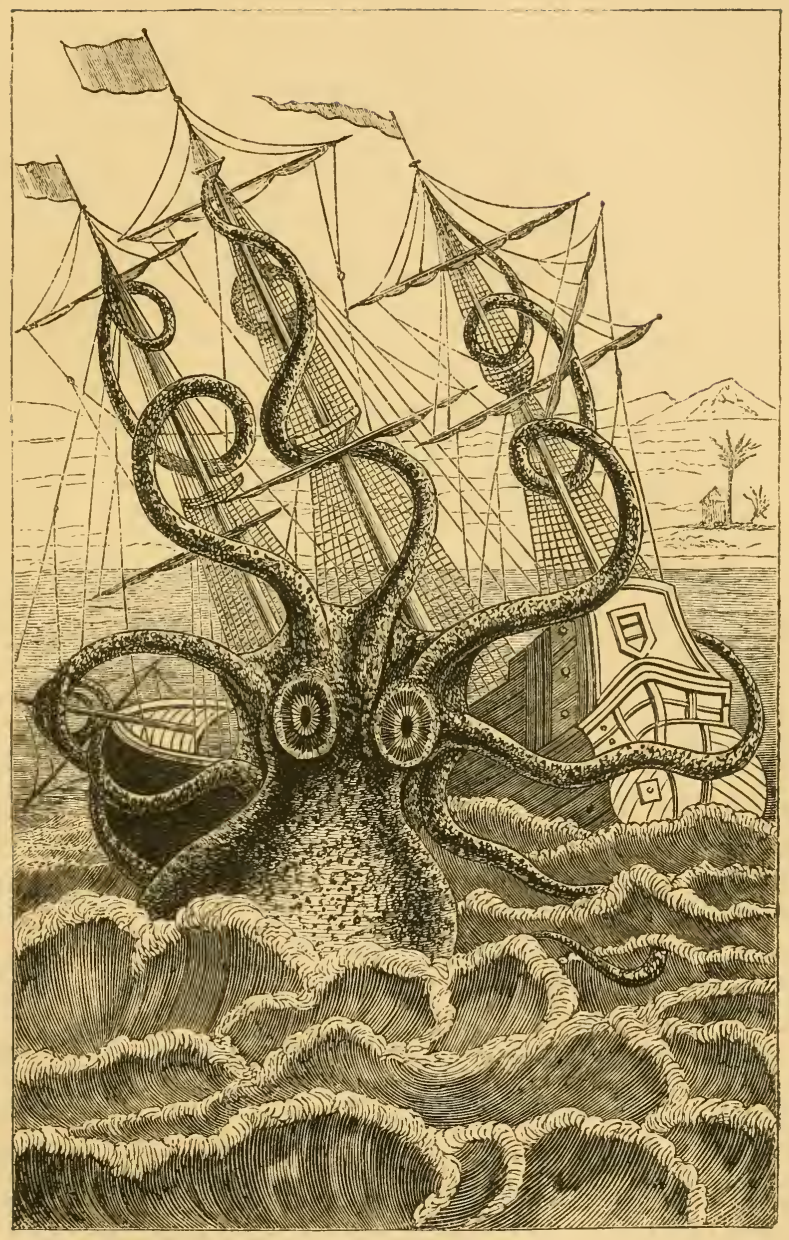

Fig. 12.-Facsimile of De Montfort's "Poulpe colossal." 

a showman's caravan at a fair than seriously to illustrate a work on natural history,* he depicted this tremendous cuttle-fish as throwing its arms over a three-masted vessel, snapping off its masts, tearing down the yards, and on the point of dragging it to the bottom, if the crew had not succeeded in cutting off its immense limbs with cutlasses and hatchets. De Montfort had good opportunities of obtaining information, for he was at one time an assistant in the geological department of the Museum of Natural History in Paris ; and wrote a work on conchology, + besides that already referred to. But it appears to have been his deliberate purpose to cajole the public; for it is reported that he exclaimed to M. Defrance : "If my entangled ship is accepted, I will make my 'colossal poulpe' overthrow a whole fleet." Accordingly we find him gravely declaring $\ddagger$ that one of the great victories of the British navy was converted into a disaster by the monsters which are the subject of his history. He boldly asserted that the six men-of-war captured from the French by Admiral Rodney in the West Indies on the 12 th of April, 1782 , together with four British ships detached from his fleet to convoy the prizes, were all suddenly engulphed in the waves on the night of the battle under such circumstances as showed that the catastrophe was caused by colossal cuttle-fishes, and not by a gale or any ordinary casualty.

Unfortunately for De Montfort the inexorable logic of facts not - only annihilates his startling theory, but demonstrates the reckless falsity of his pla!nsible statements. The captured vessels did not sink on the night of the action, but were all sent to Jamaica to refit, and arrived there safely. Five months afterwards, however, a convoy of nine line-of-battle-ships (amongst which were Rodney's prizes), one frigate, and about a hundred merchantmen, were dispersed, whilst on their voyage to England, by a violent

* "Histoire Naturelle générale et particulière des Mollusques," vol. ii., p. 256.

+ "Conchyliologie Systématique."

¥ "Hist. Nat. des Moll.," vol. ii., pp. 358 to 368 . 
storm, during which some them unfortunately foundered. The various accidents which preceded the loss of these vessels was related in evidence to the Admiralty by the survivors, and official documents prove that De Montfort's fleet-destroying poulpe was unequivocally a "devil-fish of fiction," and that the "devil-fish of fact" had no part in the disaster he ascribes to it."

* De Montfort encleavoured to support his statements by so many inaccurate details, which by a considerable number of uneducated persons of his own nation were accepted as true, that I think some particulars of the events above referred to may be interesting. My information is obtained from Rodney's despatches, and paragraphs of contemporary naval news published in the "Gentleman's Magazine" of $\mathrm{I}_{7} \delta_{2}$ and $\mathrm{I} 78_{3}$; from the "Annual Register" of $I_{3} \delta_{3}$; and from Capt. J. N. Inglefield's own account of the loss of his ship the "Centaur," in a rare pamphlet of thirty-nine pages, "published by authority," and clated "Fayall, October I3th, I782."

In Sir G. B. Rodney's action with the French fleet under the Count de Grasse, off St. Domingo, on the I2th of April, I782, the manceuvre of breaking the enemy's line, and separating some of his ships from the remainder, was for the first time successfully put in practice. The following captures were made by the British, viz. :-The admiral's ship, "Ville de Paris," 104, which was a splendid present from the City of Paris to Louis XV.; the "Glorieux;" 74;

Casar," 74; "Hector," 64; "Caton," 64; "fason," 64; "Aimable," 32 ; and "Cercs," I8; besides one ship of 74 guns, sunk during the engagement. The "Casar," one of the best ships in the French fleet, took fire on the night of the action, and, before the prisoners could be remored from her, blew up. By this accident a lieutenant, the boatswain, and fifty Englishmen belonging to the "Centaur," together with about four hundred Frenchmen, perished. The remainder of the prizes were sent into Port Royal, Jamaica, to repair - Zamages, and on the 5th of May, I782, Rodney wrote to the Admiralty announcing their safe arrival in that harbour.

On the 26th of July following, a fleet and convoy, amongst which were these ships, left Port Royal for England, under the command of Admiral Graves in the "Ramilies." They encountered several very heavy gales of wind, and on the I6th of September, in lat. $42^{\circ} 15^{\prime}$, long. $48^{\circ} 55^{\prime}$, a storm set in which lasted several days. About three A.M. on the $I 7$ th, the wind, which had been blowing from S.E., suddenly shifted, and a brief lull was succeeded by a most violent squall, with furious rain from N.N.W., which is described as "exceeding in degree everything of the kind that the oldest seaman in the fleet had ever seen, or had any conception of." The "Ramilies" went to the bottom soon after four P.M. on the 2 Ist. Most of her crew were saved. The "Centaur" foundered on the night of the $23 \mathrm{rd}$, in lat. $48^{\circ} 32^{\prime}$, long. $43^{\circ} 20^{\prime}$. Her captain, 
I have been told, but cannot vouch for the truth of the report, that De Montfort's propensity to write that which was not true, culminated in his committing forgery, and that he died in the galleys. But he records a statement of Captain Jean Magnus Dens, said to have been a respectable and veracious man, who, after having made sereral voyages to China as master of a trader, retired from a seafaring life and lived at Dunkirk. He told De Montfort that in one of his voyages, whilst crossing from St. Helena to Cape Negro, he was becalmed, and took advantage of the enforced idleness of the crew to have the vessel scraped and painted. Whilst three of his men were standing on planks slung over the side, an enormous cuttle-fish rose from the water, and threw one of its arms around two of the sailors, whom it tore away, with the scaffolding on which they stood. With another arm it seized the third man, who held on tightly to the rigging, and screamed for help. His shipmates ran to his assistance, and succeeded in rescuing him by cutting away the creature's arm

Inglefield, and eleven of her people, in the pinnace, left her in a sinking state about five o'clock on that evening, and after suffering severely for sixteen clays, in the course of which one man, Thomas Matthews, quartermaster, died from cold and exposure, they landed at Fayall in an exhausted condition, having macie a voyage of more than 750 miles in a open boat. The "Glorizux" and the "Ville de Paris" also sank during the gale, and only one man of the crew of the latter vessel was saved, having been picked up on some floating wreck. His name was John Wilson, and he gave evidence at Portsmouth concerning the disaster on the 22nd of March, I $7 S_{3}$. The "Caton," "Canada," "Ardent," and "Fason" escaped with loss of spars and other damage. The "Hector" was"attacked by two French frigates, left by them in a crippled condition, and sank-many of the crew being saved by the "Hawliesnow," letter of marque. These are well-attested facts. De Montfort's fabulous statement was, that on the night following the battle, the "Ville de Paris" fired minute guns and made other signals of extreme distress, and that in consequence of this nine other men-of-war bore down to her assistance, converging on her as a common focus, and were all simultaneously involved in her mournful fate-that of being dragged beneath the yawning waves by enormous poulpes. His pretended history, as well as his ingenious, but disingenuous theory, was drawn from his imagination; and the one is as false as the other is absurd. 
with axes and knives, but he died delirious on the following night. The captain tried to save the other two sailors by killing the animal, and drove several harpoons into it; but they broke away, and the men were carried down by the monster. The arm cut off was said to have been 25 feet long, and as thick as the mizenyard, and to have had on it suckers as big as saucepan-lids. I believe the old sea-captain's narrative of the incident to be true: the dimensions given by De Montfort are an embellishment of his own.

It is remarkable that there exists in the East a strong belief in the power of these animals to sink a ship and devour her crew. I have been told by a friend that he saw in a shop in China a picture of a cuttlefish embracing a junk, apparently of about 300 tons burthen, and helping itself to the sailors, as one picks gooseberries off a bush. Mr. Laurence Oliphant, in his "China and Japan," describes a Japanese show, which consisted of "a series of groups of figures carved in wood, the size of life, and as cleverly coloured as Madame Tussaud's wax-works. One of these was a group of women bathing in the sea. One of them had been caught in the folds of a cuttle-fish; the others, in alarm, were escaping, leaving their companion to her fate. The cuttlefish was represented on a huge scale, its eyes, eyelids, and mouth being made to move simultaneously by a man inside the head."

The old stories of colossal cuttle-fishes, though gross exaggerations, are "founded on facts." They are based on the rare occurrence of specimens, smaller certainly, but still enormous, of some known species. The means of observation on the duration of growth and life in the cephalopods have been, of course, difficult to obtain; but, from watching the rate of increase of size in young specimens, De Ferussac, D'Orbigny, and other naturalists have arrived at the conclusion that they sometimes live for many years, and continue to grow till the end of their lives. That some of them, therefore, should attain to a considerable magnitude is hardly surprising.

Passing over the earlier records of the appearance of cuttle- 
fishes of unusual size, and the current as well as traditional belief in their existence by the inhabitants of many countries, let us take the testimony of travellers and naturalists, who have a right to be regarded as competent observers.

Peron,* the well-known French zoologist, mentions having seen at sea, in $180 \mathrm{r}$, not far from Van Diemen's Land, at a very little distance from his ship, "Le Géographe," a sepia (calamary?) of the size of a barrel, rolling with noise on the waves; its arms, between 6 and 7 feet long, and 6 or 7 inches in diameter at the base, extended on the surface, and writhing about like great snakes.

Quoy and Gaimard + report that in the Atlantic Ocean, near the equator, they found the remains of an enormous calamary, halfeaten by the sharks and birds, which could not have weighed less, when entire, than $200 \mathrm{lbs}$.

Captain Sander Rang tr records having fallen in with, in midocean, a species distinct from the others, of a dark red colour, having short arms, and a body the size of a hogshead.

Molina, in his "Natural History of Chili," describes, amongst other species of cuttlefishes, one, which he calls Sepia tunicata, and of which he says some specimens, armed with hooks in their suckers, weighed $\mathrm{r} 5$ olbs.

Although, in the face of recent discoveries, it is now comparatively unimportant, I may here mention that Schneider, $§$ a most able and scrupulously careful naturalist, finding that, in many instances, Molina was utterly unworthy of confidence, plainly declared that it was necessary to search in the works of others for description of the species of which he wrote, and expressed doubts of the correctness of his assertions concerning the hookfurnished cuttle-fish on the coast of Chili. He could not discover

* "Voyage de Découvertes aux Terres australes."

* "Voyage de l'Uranie : Zoologie :" vol. i., part 2, p. 4r I. I824.

‡ “Manuel des Mollusques," p. 86.

$\S$ “"Bemerk, Uber die Gattung der Dintenfisch, etc.," I793. 
the source whence Molina had derived his information on this subject, but M. de Ferussac * found that he had taken it from a translation of the narrative of Captain Cook's first voyage, and had dishonestly transferred to Chili a specimen (to which I shall presently refer), described by Sir Joseph Banks as captured in the South Seas, and which is now in the museum of the Royal College of Surgeons. De Montfort quoted Molina, and, with his usual love of exaggeration, greatly embellished his description. Shaw reproduced De Montfort's figure, and Leach and Lesueur accepted Molina's statements. $\dagger$

In a manuscript by Paulsen, referred to by Professor Steenstrup, of Copenhagen, is a description of a large calamary cast ashore on the Danish coast, which the latter named Architcuthis monachus. Its body measured 2 f feet, and its tentacles i 8 feet, making a total of 39 feet.

In I $_{54}$ another was stranded at the Skag in Jutland, which Professor Steenstrup believed to belong to the same genus as the preceding, but to be of a different species, and called it Architeuthis alux. The body was cut in pieces by the fishermen, and furnished many wheelbarrow-loads. Mr. Gwyn Jeffreys $\neq$ says

* "Note sur la Seiche à six pattes, Sipia hexopodia de Molina, et sur deux autres espèces de Seiches signalées par cet auteur."

+ De Ferussac severely denounces Molina's lack of truthfulness, and administers a rebuke which may be useful to some writers of the present day. Whilst avoiding the imputation of wilful repetition and propagation of falsehood, he gravely censures the acceptance of error as truth. He says :- "This suggests sad reflections on the amplifications, reticences, and fantastic inventions of some savans, and on the absence of scrutiny apparent in some scientific works. It should serve to prove, more and more, the necessity of careful examination before accepting or rejecting doubtful species, although it is more convenient to accept statements as they are found, without taking the trouble to verify them by proper research. We know very well that the majority of naturalists, with the exception of a small number of especially pains-taking men, are unaware of the negligence, the double use of incidents, and the repetition of innumerable errors to which those who are content thus to work expose themselves."

¥ "British Conchology," vol. v., p. I 24 . 
Dr. Mörch informed him that the beak of this animal was nine inches long. He adds that another huge cephalopod was stranded in 1860 or $186 \mathrm{r}$, between Hillswick and Scalloway, on the west of Shetland. From a communication received by Professor Allman, it appears that its tentacles were 16 feet long, the pedal arms about half that length, and the mantle sac 7 feet. The largest suckers examined by Professor Allman were three-quarters of an inch in diameter.

We have also the statement of the officers and crew of the French despatch steamer, "Alecton," commanded by Lieutenant Bouyer, describing their having met with a great calamary on the 3 oth of November, I86I, between Madeira and Teneriffe. They say that the body of the creature, which, like Rang's specimen, was of a deep red colour, measured i 6 feet to $\mathrm{I} 8$ feet in length, without reckoning that of the formidable arms. The harpoons thrust into it drew out of its soft flesh; so they slipped a rope with a running knot over it, which held at the juncture of the fins; but when they attempted to haul it on board, the enormous weight caused the rope to cut through the flesh, and all but the hinder part of the body fell back into the sea and disappeared. II. Berthelot, the French Consul at Teneriffe, saw the fins and posterior portion of the animal on board the "Alccton" two days afterwards, and sent a report of the occurrence to the Paris Academy of Sciences.*

These are statements made by men who, by their intelligence, character, and position, are entitled to respect and credence, and whose evidence would be accepted without question or hesitation in any court of law. There is, moreover, a remarkable coincidence of particulars in their several accounts, which gives great importance to their combined testimony. The public, after being deceived by Pliny with his rapacious colossal polypus, and by

* In the illustration of this occurrence given in M. Louis Figuier's book, "La Vie et les Mœurs des Animaux," and the English translations of it, the size of the calamary is so exaggerated that undeserved discredit has been brought by it on the narrators of the incident. 
Olaus Magnus, Pontoppidan and De Montfort with their fabulous or grossly exaggerated "Kraken," leaped hastily across the path of truth from easy gullibility on the one hand to unreasoning incredulity on the other. "In medio tutissimus ibis" is a rule which may be safely applied to this case, as to many others. The accumulated weight of such aggregate testimony as had been adduced should, even if unsupported by confirmatory facts, have been sufficient to convince any thoughtful inquirer of the existence of very large cephalopods, individuals of which have occasionally been seen, and correctly described by some trustworthy observers, although absurdly exaggerated and misrepresented by others.

But fortunately, we are not left dependent on documentary evidence alone, nor with the option of accepting or rejecting, as caprice or prejudice may prompt us, the narratives of those who have told us they have seen what we have not. Cuttle-fishes of extraordinary size are preserved in several European museums. In the collection of the Faculty of Sciences at Montpellier is one six feet long, taken by fishermen at Cette, which Professor Steenstrup has identified as Ommastrephes pteropus. One of the same species, which was formerly in the possession of M. Eschricht, who received it from Marseilles, may be seen in the museum at Copenhagen. The body of another, analogous to these, is exhibited in the museum of Trieste. It was taken on the coast of Dalmatia. At the meeting of the British Association at Plymouth in $184 \mathrm{r}$, Colonel Smith exhibited drawings of the beak and other parts of a very large calamary preserved at Haarlem; and M. P. Harting, in $\mathrm{r} 860$, described in the Memoirs of the Royal Scientific Academy of Amsterdam portions of two extant in other collections in Holland, one of which he believes to be Steenstrup's Architenthis dux, a species which he regards as identical with Ommastrephes todarus of D'Orbigny. Dr. J. E. Gray scientifically described, many years ago, in his "Spicilegia Zoologica," a specimen of Sepiotenthis major from the Cape of Good Hope, the body of which measured 27 inches, the head 6 inches, and the fins and 
body 7 inches each in breadth, and mentions one seen by Mrs. Graham, which had arms 28 feet long.

In the Museum of the Royal College of Surgeons are portions of an Onychoteuthis or Enoploteuthis (a squid, the suckers of which are furnished with prehensile hooks), found floating by Drs. Banks and Solander between Cape Horn and the Polynesian Islands, and described as having been 6 feet in length, including the tentacular arms.* The lower portion of the body, with the fins attached, in a dried and shrunken condition, is 18 inches long; the beak, $3 \frac{1}{2}$ inches. A part of one of its arms, with the hooked suckers, is also to be seen, which, however, being only the tip of one, gives no clue to its entire length.

Still there remained a residuum of doubt in the minds of naturalists and the public concerning the existence of gigantic cuttle-fishes until, towards the close of the year I873, two specimens were encountered on the coast of Newfoundland, and a portion of one and the whole of the other were brought ashore and preserved for examination by competent zoologists.

The circumstances under which the first was seen, as sensationally described by the Rev. M. Harvey, Presbyterian minister of St. John's, Newfoundland, in a letter to Principal Dawson, of McGill College, were, briefly and soberly, as follows :-Two fishermen were out in a small punt on the 26 th of October, 1873 , near the eastern end of Belle Isle, Conception Bay, about nine miles from St. John's. Observing some object floating on the water at a short distance they rowed towards it, supposing it to be the débris of a wreck. On reaching it one of the men struck it with his "gaff" when immediately it showed signs of life, and shot out its two tentacular arms, as if to seize its antagonists. One of the men severed both arms with an axe as they lay on the gunwale of the boat, whereupon the animal moved off, and ejected a quantity of inky fluid which darkened the surrounding water for a considerable distarce.

* This is the specimen described by Molina. 
The men went home and magnified their adventure. They " estimated" the body to have been 60 feet in length and 10 feet across the tail fin; and declared that when the "fish" attacked them "it reared a parrot-like beak which was as big as a sixgallon keg."

All this Mr. Harvey appears to have been willing to believe, and relates without the expression of a doubt. Fortunately, he was able to obtain from the fishermen a portion of one of the tentacular arms which they had chopped off with the axe, and it is now in the St. John's Museum. By careful calculation of its girth, the breadth and circumference of the expanded suckerbearing portion at its extremity, and the diameter of the suckers, Professor Verrill, of Yale College, has computed its dimensions as follows:-Length of body ro feet; diameter of body 2 feet 5 inches. Long tentacular arms 32 feet; head 2 feet-total length about 44 feet. The upper mandible of the beak, instead of being " as large as a six-gallon keg" would be about 3 inches long, and the lower mandible $\mathrm{I} \frac{1}{2}$ inch long. From the size of the large suckers relatively to those of another specimen to be presently described, he regards it as probable that this individual was a female.

In November, I 874,-about three weeks after the occurrence in Conception Bay-a calamary somewhat smaller than the preceding, but of the same species, also came into Mr. Harvey's possession. Three fishermen, when hauling their herring-net in Logie bay, about three miles from St. John's, found the huge animal entangled in its folds. With great difficulty they succeeded in despatching it and bringing it ashore, being compelled to cut off its head before they could get it into their boat.

The body of this specimen was over 7 feet long; the caudal fin 22 inches broad; the two long tentacular arms 24 feet in length; the eight shorter arms each 6 feet long, the largest of the latter being ro inches in circumference at the base; total length of this calamary 32 feet. Professor Verrill considers that this and the 
Conception Bay squid are both referable to one species-Steenstrup's Architeuthis dux.

Excellent woodcuts from photographs of these two specimens were given in the "Field" of January 3 Ist, I 874 , and December I 3 th, I873, respectively.

In the "American Journal of Science and Arts," of March, 1875, Professor Verrill gives particulars of several other examples of great calamaries, varying in total length from 30 feet to 52 feet, which have been taken in the neighbourhood of Newfoundland since the year 1870 .

The following account of the still more recent capture of a large squid off the west coast of Ireland was given in the "Zoologist" of June, I 875, by Sergeant Thomas O'Connor, of the Royal Irish Constabulary :-

"On the 26th of April, I875, a very large calamary was met with on the north-west of Boffin Island, Connemara. The crew of a 'curragh' (a boat made like the 'coracle,' with wooden ribs covered with tarred canvas) observed to seaward a large floating mass, surrounded by gulls. They pulled out to it, believing it to be wreck, but to their astonishment found it was an enormous cuttle-fish, lying perfectly still, as if basking on the surface of the water. Paddling up with caution they lopped off one of its arms. The animal immediately set out to sea, rushing through the water at a tremendous pace. The men gave chase, and, after a hard pull in their frail canvas craft, came up with it, five miles out in the open Atlantic, and severed another of its arms and the head. These portions are now in the Dublin Museum. The shorter arms measure each $\delta$ feet in length, and I 5 inches round the base : the tentacular arms are said to have been 30 feet long. The body sank."

Finally, there is in the basement chambers of the British Museum (irreverently called the "spirit vaults and bottle department," because fish, mollusca, \&c., in spirits are there deposited) a tall glass jar, in which is preserved a single arm of a huge 
cephalopod, which, by the kindness and courtesy of the officers of the department, I was permitted to examine and measure when I first described it, in May, r873. It is 9 feet long, and ro inches in circumference at the base, tapering gradually to a fine point. It has about 300 suckers, pedunculated, or set on tubular footstalks, placed alternately in two rows, and having serrated, horny rings, but no hooks ; the diameter of the largest of these rings is half an inch; the smallest is not larger than a pin's head. This is one of the eight shorter, or pedal, and not one of the long, or tentacular, arms of the calamary to which it belonged. Judging from the proportions of known examples, I estimate the length of the tentacles at 36 feet, and that of the body at from I I to I 2 feet: total length 48 feet. The beak would probably have been about 5 inches long from hinge socket to point. No history relating to it has been preserved; but Dr. Gray told me that he believed it came from the east coast of South America.

Here, then, in our midst, and to be seen by all who wish to inspect it, is, and has long been, a limb of a once-living cephalopod capable of upsetting a boat, or of hauling a man out of her, or of clutching one engaged in scraping a ship's side, and dragging him under water, as described by the old master-mariner, Magnus Dens ; possessing, also, a beak powerful enough to tear him in pieces, and crush some of his smaller bones. I confess that until I saw and measured this enormous limb, I doubted the accuracy of some early observations which this specimen alone would suffice to prove worthy of confidence. The existence of gigantic cephalopods is no longer an open question. I, now, more than ever, appreciate the value of the adage :

"TRUth is Stranger than Fiction."

THE END. 


\section{CHARLES DICKENS'S WORKS.}

\section{TH $\mathrm{F}$ \\ ILLUSTRATED LIBRARY EDITION}

OF THE

\section{WORKS OF CHARLES DICKENS.}

To be completed in 30 Monthly Volumes. Demy 8vo, price Ios. each.

This edition will be printed on a finer paper and in a larger type than has been employed in any previous edition. The type has been cast especially for it, and the page will be of a size to admit of the introduction of all the original illustrations. These will be printed from the steels and blocks on which the original artists themselves were engaged.

No such attractive issue has been made of the writings of Mr. Dickens, which, various as have been the forms of publication adapted to the demands of an ever-widely increasing popularity, have never yet been worthily presented in a really handsome library form.

The want has been extensively felt, and is so often brought under the notice of Messrs. Chapman and Hall that the present enterprise is undertaken to satisfy it.

The collection will comprise all the minor writings it was Mr. Dickens's wish to preserve, and the series of tales will be issued in the order in which they were written.

\section{Volumes already published.}

SKETCHES BY "BOZ." With 40 Illustrations by GEORGE CRUIKSHank.

PICKWICK. 2 vols. With 42 Illustrations by "PHIz."

OLIVER TWIST. With 24 Illustrations by CRUIKSHANK.

NICHULAS NICKLEBY. 2 vols. With 40 Illustrations by " PHIz."

OLD CURIOSITY SHOP, AND REPRINTED PIECES. 2 vols. With Illustrations

by CATTERMOLE, \&c.

BARNABY RUDGE AND HARD TIMES. 2 vols. With Illustrations by CATTERMOLE, \&C.

MARTIN CHUZZLEWIT. 2 vols. With 40 Illustrations by "PHIz."

AMERICAN NOTES AND PICTURES FROM ITALY. I vol. With 8 Illustrations.

DOMBEY AND SON. 2 vols. With 40 Illustrations by "Phiz."

COPPERFIELD. 2 vols. With 40 Illustrations by "PHiz."

BLEAK HOUSE. 2 vols. With 40 Illustrations by "PHiz."

LITTLE DORRIT. 2 vols. With 40 Illustrations by "PHIz."

A TALE OF TWO CITIES. With I6 Illustrations by "PHIz."

\section{THE "CHARLES DICKENS" EDITION. In crown 8 vo.}

\section{In 21 vols. cloth, with 8 Illustrations each, £3 9s. $6 d$.}

PICKWICK PAPERS

MARTIN CHUZZLEW

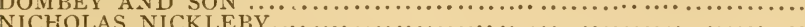

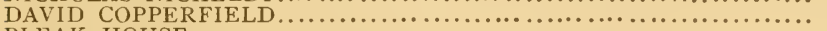

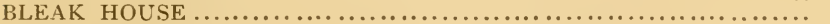

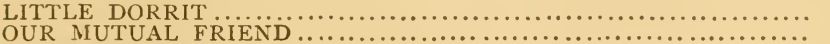

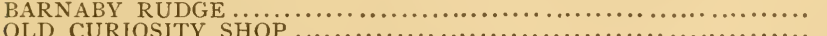

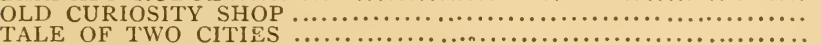

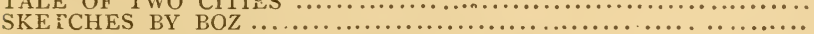

AMERICAN NOTES AND REPRINTED PIECES $\ldots \ldots \ldots \ldots \ldots \ldots \ldots \ldots \ldots$

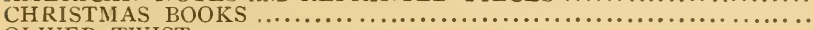

OLIVER TIVIST

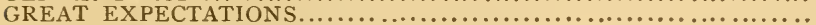

HARD TIMES AND PICTURES FRÖ

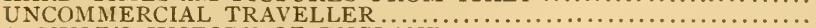

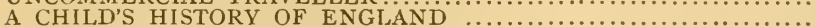

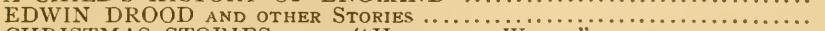

CHRISTMAS STORIES, FROM "HousEHOLD WORDS" $\ldots \ldots \ldots \ldots \ldots \ldots \ldots . .$.

$\begin{array}{lll}\text { t } & s . & d . \\ 0 & 3 & 6 \\ 0 & 3 & 6 \\ 0 & 3 & 6 \\ 0 & 3 & 6 \\ 0 & 3 & 6 \\ 0 & 3 & 6 \\ 0 & 3 & 6 \\ 0 & 3 & 6 \\ 0 & 3 & 6 \\ 0 & 3 & 6 \\ 0 & 3 & 0 \\ 0 & 3 & 0 \\ 0 & 3 & 0 \\ 0 & 3 & 0 \\ 0 & 3 & 0 \\ 0 & 3 & 0 \\ 0 & 3 & 0 \\ 0 & 3 & 0 \\ 0 & 3 & 6 \\ 0 & 3 & 6 \\ 0 & 3 & 6\end{array}$

CHAPMAN AND HALL, 193, PICCADJLLY. 


\section{THOMAS CARLYLE'S WORKS.}

\section{LIBRARY EDITION COMPLETE.}

Handsomely printed in 34 vols., demy 8vo, cloth.

SARTOR RESARTUS. The Life and Opinions of Herr Teufelsdröckh. With a Portrait, 7 s. 6 d.

THE FRENCH REVOLUTION : a History. 3 vols., each gs.

LIFE OF FREDERICK SCHILLER AND EXAMINATION OF HIS WORKS.

With Supplement of 1872 , Portrait and Plates, 9 s. The Supplement separately, $2 s$.

CRITICAL AND MISCELLANEOUS ESSAYS. 6 vols., each 9 s.

ON HEROES, HERO WORSHIP, AND THE HEROIC IN HISTORY. 7 s. $6 . \%$. PAST AND PRESENT. With a Portrait, 9 .

OLIVER CROMWELL'S LETTERS AND SPEECHES. With Portrits, 5 vols., each 9 s.

LATTER-DAY PAMPHLETS. 9s.

LIFE OF JOHN STERLING. With Portrait, $9 s$.

HISTORY OF FREDERICK THE SECOND. Io vols., each $g$ s.

TRANSLATIONS FROM THE GERMAN. 3 vols., each gs.

GENERAL INDEX TO THE LIBRARY EDITION. 8vo, cloth, 6 s.

\section{PEOPLE'S EDITION. \\ In 37 Vols., small crown 8vo. Price 2s. each Vol., bound in cloth; or in sets of 37 Vols. in 18 , cloth gilt, for $£_{3} 14$ s.}

SARTOR RESARTUS.

FRENCH REVOLUTION. 3 Vols.

LIFE OF JOHN STERLING.

OLIVER CROMWELL'S LETTERS

AND SPEECHES. 5 Vols.

ON HEROES AND HERO WORSHIP.

PAST AND PRESENT.
CRITICAL AND MISCELLANEOUS ESSAYS. 7 Vols.

LATTER-DAY PAMPHLETS.

LIFE OF SCHILLER.

FREDERICK THE GREAT. Io Vols.

WILHELM MEISTER. 3 Vols.

TRANSLATIONS FROM MUSEUS,

Tieck, and Richter. ${ }^{1} 2$ Vols.

\section{WHYTE-MELVILLE'S WORKS. CHEAP EDITION.}

Crown 8vo, fancy boards. 2s. each, or 2s. 6d. in cloth.

UNCLE JOHN. A Novel,

THE WHITE ROSE.

CERISE. A Tale of the Last Century.

BROOKES OF BRIDLEMERE.

"BONES AND I :" or, The Skeleton at Home.

“M., OR N." Similia Similibus Curantur. CONTRABAND; or, a Losing Hazard.
MARKET HARBOROUGH ; or, How Mr. Sawyer went to the Shires.

SARCHEDON : A Legend of the Great Queen.

SONGS AND VERSES.

SATANELLA: A Story of Punchestown.

THE TRUE CROSS: A Legend of the Chuich.

CHAPMAN AND HALL, I93, PICCADILLY. 


\section{CHAPMAN AND HALL'S}

FOR'THCOMING PUBLICATIONS.

\section{DIDEROT.}

By JOHIN MORLEY.

Demy 8vo.

\section{NEW WORK BY \\ ROBERT, LORD LYTTON.}

A NEW EDITION OF

THE LIFE OF CHARLES DICKENS. By JOHN FORSTER.

In 2 Vols. demy 8vo, with Illustrations.

LANDOR'S WORKS.

THE LIFE AND WORKS OF WALTER SAVAGE LANDOR.

WITH PORTRAITS AND ILLUSTRATIONS.

A New Edition in the press, to be completed in 8 Vols. demy 8 ro.

The First Volume will contain a New and Revised Edition of the Life, by JOHN Forster.

$$
\text { ITAL } Y \text { : }
$$

From the Alps to Mount AEtna.

Magnificently illustrated by G. Bauenfeind, A. Bоecklin, G. Вонn, A. Calame, G. Closs, L. Dill, B. Fibdler, J. Grass, L. Heilbuth, A. Hertel, E. Katoldt, H. Kaulbach, W. V. Kaulbach, F. Keller E. Kirchner, etC., etc., עтс.

To be completed in Twelve Monthly Parts.

Containing about 70 Full-page and 300 smaller Illustrations. 
INDIA AND ITS NATIVE PRINCES:

Travels in Central India and in the Presidencies of Bombay and Bengal.

\section{By LOUIS ROUSSELET.}

Carefully revised and edited by Lieut.-Colonel C. BuckLE, and containing 316 Illustrations and 6 Maps.

\section{THE EIGHTEENTH CENTURY:} Its Institutions, Customs, and Costumes. France, I $700-1789$.

By PAUL LACROIX.

Illustrated with 21 Chromolithographs and 351 Wood Engravings.

THE TRIQUETI MARBLES IN THE ALBERT MEMORIAL CHAPEL, WINDSOR.

A SERIES OF PHOTOGRAPHS EXECUTED BY THE MISSES DAVISON. AND DEDICATED BY PERMISSION TO HER MAJESTY THE QUEEN.

The Work will consist of 117 Photographs, with descriptive letterpress, mounted on 49 sheets of Cardboard, half-imperial. Price $£ 1010 s$.

A CONCORDANCE OF THE ORIGINAL POETICAL WORKS OF ALEXANDER $P O P E$.

\section{By EDWIN ABВOTT,}

Formerly Head Master of the Philological School.

WITH AN INTRODUCTION ON THE ENGLISH OF POPE.

By EDWIN A. ABBOTT, D.D., Apthor of a "Shakespearian Grammar," etc., etc. Medium 8vo. 


\section{DYCE'S SHAKESPEARE.}

A New Edition of Drce's Shak espeare, being the Third, with Mr. Dyce's final corrections. The latest employment of Mr. DYCE's life was the present revision of his second edition.

THE WORKS OF SHAKESPEARE.

EDITED BY THE

Rev. ALEXANDER DYCE.

To be completed in 9 Vols. demy 8 vo.

Vol. VII. is now ready.

A NEW IIBRARY EDITION OF

THE HISTORY OF ENGLAND FROM ¿830 TO THE RESIGNATION OF THE GLADSTONE MINISTRY.

By the Rev. W. NASSAU MOLESWORTH, M.A.

Carefully revised, and carried up to March, 1874.

3 Vols. demy 8 vo.

A NEW EDITION OF

THE AMAZON AND MADEIRA RIVERS.

SKETCHES AND DESCRIPTIONS FROM THE NOTEBOOK OF AN EXPLORER.

By FRANZ KELLER, Ẽngineer.

With 68 Illustrations.

THE HISTORY OF GREAT BRITAIN DURING THE REIGN OF QUEEN $A N N E$.

By FREDERICK WILLIAM WYON.

2 Vols. demy 8 ro. 
4 CHAPMAN AND HALL'S NEW WORKS.

THE LIFE AND TIMES OF PRINCE

CHARLES STUART, COUNT OF $A L B A N Y$.

COMMONLY CALLED THE YOUNG PRETENDER.

From the State Papers and Other Sources.

BY ALEXANDER CHARLES FWALD, F.S.A., Author of "The Life and Times of Algernon Sydney," "The Crown and its Adrisers, etc.

2 Vols. demy Svo.

\section{FORTY YEARS' RECOLLECTIONS OF LIFE, LITERATURE, AND ART. BY CHARLES MTACKAY, I.L.D. \\ 2 Vols. demy 8 vo.}

NEW NOVEL BY ANTHONY TROLLOPE.

THE PRIMIE MINISTER.

By ANTHOINY TROILOPE.

NEW WORK BY WHYTE-MELVILIE.

SISTER LOUISE.

By G. J. WHYTE-MIELVILLR.

NEW INOVEL BY GFORGE MEREDITH. BEAUCHAMP'S CAREER.

BY GEORGP MEREDITH.

3 Vols. 
NEW NOVEL BY LADY WOOD.

$$
\text { BELOW THE SALT. }
$$

BY LADY WOOD.

NOVEL BY THE AUTHOR OF "SONGS OF THE SIERRAS."

THE ONE FAIR WOMAN.

BY JOAQUIN MILLER.

NEW NOVEL BY "OLD CALABAR."

GRAY ABBEY.

By OLD CALABAR.

Author of "Jack Blake," "Over Turf and Stubble," "Won in a Canter," etc.

NEW NOVEL BY THE AUTHOR OF "AUNT MARGARET'S TROUBLE."

A CHARMING FELLOW.

BY FRANCFS PLEANOR TROLLOPE,

Author of "Aunt Margaret's Trouble," "Mabel's Progress," ete., etc.

OUR FRAÜLEIN: An Anglo-Teuton Tale.

By W. H. WATTS,

Author of Oddities of "I Iondon Life," "My Private Notebook," etc., etc.

SPIDERS AND FLIES.

A Novet.

By MRS. HARTLEY,

Author o! "Hilda and I." 


\section{OLIVIA RALEIGH. By W. W. FOLLETT SYNGE.}

\section{SPORT IN MANY LANDS.}

\section{By HAL, "THE OLD SHEKARRY,"}

Author of "The Hunting-ground of the Old World," "The Forest and the Field," "Camp Life and its Acquirements for Soldiers, Sportsmen, and Travellers," etc., etc.

With 200 Illustrations. Demy 8vo.

\section{THE RAMBLES OF A GLOBE} TROTTER in Australia, Fapan, China, Fava, India, and Cashmere.

By F. K. LAIRD.

With Map and 40 Photographs. 2 Vols. demy 8 vo.

\section{MELINDA, THE CABOCEER; OR, SPORT IN ASHAN'TI.}

A TALE OF THE GOLD COAST.

By J. H. SKERTCHLY, Author of "Dahomey as it Is," etc. etc.

With Mllustrations. Post Svo.

TWELVE MONTHS IN SOUTHERN

$$
\text { EUROPE. }
$$

By MRS. BLAKE.

With Illustrations. Demy 8 ro. 


\section{TALES OF AUSTRALIAN LIFE.}

\section{By N. WALTER SWAN.}

Crown 8 vo.

\section{ARDENMOHR: AMONG THE HILLS.}

A RECORD OF SCENERY AND SPORT IN THE HIGHLANDS OF SCOTLAND.

\section{By SAMUEL ABBOTT.}

With Sketches and Etchings by the Author.

\section{A HANDBOOK OF ARCHITECTURAL STYLES.}

TRANSLATED FROM THE GERMAN OF A. ROSENGARTEN, By W. COLLETT-SANDARS.

With upwards of 600 Illustrations. One Vol. large demy 8 vo.

\section{THE AMATEUR HOUSE CARPENTER •}

$A$ Guide in Building, Making, and Repairing.

Containing:-Full Instructions for Making Useful and Ornamental Articles-For Constructing Various Buildings in Wood, with Descriptions of the Tools Employed-The Methods of Lengthening and Joining Timber-The General Principles of Building in Brick and Stone-The Processes of Staining, Painting, Polishing, and Varnishing Woodwork - Together with the Elements of Architectural Drawing and Colouring.

\section{By ELLIS A. DAVIDSON,}

Author of "Building Construction," "Drawing for Carpenters and Joiners,"

"The Boy Joiner," etc., etc., etc.

With Numerous Illustrations, Drawn on Wood by the Author. 
SOUTH KENSINGTON MUSEUM ART-HANDBOOKS.

EDITED BY

WILLIAM MASKELL.

1. TEXTILE FABRICS.

By the Very Rev. Daniel Rock, D.D.

With Numerous Woodcuts. Large crown 8vo.

2. IVORIES : ANCIENT AND MEDIREAL.

By William Maskell.

With Numerous Woodcuts. Large crown 8vo.

3. ANCIENT AND MODERN FURNITURE AND WOODWORK.

By Johr Hungerford Polien.

With Numerous Woodcuts. Large crown 8vo.

4. MAIOLICA.

By C. Drury E. Fortnum, F.S.A.

With Numerous Woodcuts. Large crown 8vo.

5. MUSICAL INSTRUMENTS.

By Cari Exgel.

With Numerous Woodcuts. Large crown 8vo.

GUIDE TO THE COLLECTION
OF ECONOMIC ENTOMOLOGY IN THE

BETHNAL GREEN MUSEUM.

PART I.-MYRIAPODS.

By ANDREW MURRAY, F.I.S. 



